Baran Aydin

\title{
The Hellenistic Pottery and Small Finds of Kordon Tumulus at Kordon Köyü/Salihli (Manisa) 2001*
}

\section{Introduction}

This paper aims to publish hellenistic finds from a tumulus grave in the territory of Sardis aided by publications after $2001^{1}$. Since little datable contexts are known for hellenistic pottery from Sardis ${ }^{2}$ it is helpful to present some useful contexts. Furthermore it is also intended to present new finds of known and unknown workshops as well as a unique wooden pyxis.

Kordon Tumulus $^{3}$ (fig. 1) is located $18 \mathrm{~km}$ east of Sardis and $1 \mathrm{~km}$ south of Kordon Köy $\ddot{u}^{4}$. Its GPS coordinates are N 38 26'50.5', E 28 $8^{\circ} 15^{\prime}$ 52.2" and in UTM System E610345 N4256211 (UTM zone 35) elv. $268 \mathrm{~m}$. Since C. Foss ${ }^{5}$ draws the borders of Roman Sardis $15 \mathrm{~km}$ west till to Aureliopolis, $20 \mathrm{~km}$ northeast as far as Adala, $30 \mathrm{~km}$ east as far as Philadephia, it seems plausible to consider these Kordon finds as \Sardian<. It is worth mentioning that the Hellenistic pottery of Sardis has a close relationship to the pottery of Pergamum ${ }^{6}$. At the end of the field research it became clear that the tomb was built in the beginning of the 5 th century BC by the Lydians and was re-used in the 2 nd century BC as a family grave. The tomb's form can be placed between 〉Group $\mathrm{P}$ « and 〉Group R tumuli .

\footnotetext{
* For abbreviations additional to those published in $<\mathrm{http} / /$ www.oeai.at/publik/autoren.html $>$ see the end of this contribution. ${ }^{1}$ Here the term >glazed is used as Rotroff - Oliver 2003 did for Hellenistic slips.

2 On the dating of Sardis Hellenistic Pottery, s. Rotroff - Oliver 2003, 93: Archaeological evidence from the Hellenistic strata at Sardis is quite disturbed. There is, however an accepted historical event, namely the destruction of the city in $213 \mathrm{BC}$ by Antiochos III, of which evidence can be found in Sardis, Pactolus north (PN) sector. The Hacioğlan necropolis (ca. 300 BC), the tomb of the Lintel at PC area $(175 \mathrm{BC})$ and artifacts found beneath the $17 \mathrm{AD}$ earthquake debris provide further points for dating. For example, moldmade relief bowls were not noted in this destruction debris, nor were they found in the Roman cemetery at Ahlatlı Tepecik which was dated by coins to the period ca. 50-117 AD. For the division of Hellenistic contexts s. Hanfmann 1983, 111. It is divided into three periods: a) early, 334-213 BC; b) middle, 213-133 BC; and c) late, 133 AD-17 BC.

${ }^{3}$ The tomb was excavated by the archaeologist B. Aydın from the Manisa Museum (now at the Çeşme Museum) with the support of Prof. Dr. C. H. Greenewalt and Prof. Dr. C. H. Roosevelt from the Harvard-Cornell expedition at Sardis. I owe my thanks to Prof. Dr. G. Bakır from Ege University for offering me this subject as a MA thesis. I am also grateful to Prof. Dr. F. Krinzinger and the Ephesos expedition for their general support on library research. I owe especially thanks to Doz. Dr. S. Ladstätter for proof reading and valuable comments.

${ }^{4}$ Although there are no visible ancient sites near the tomb, the name of the village Kordon is similar to >Korakoenon< which was mentioned as a place name in a Roman period inscription, s. H. Malay, Greek and Latin Inscriptions in the Manisa Museum, ETAM 19 (Vienna 1994) 36 no. 38 fig. 11.

${ }^{5}$ Hanfmann 1983, 1.

${ }^{6}$ Hanfmann 1983, 125-126, s. also note 15: In the first half of the 2nd c. imitations of Pergamene West Slope Style vases, grooved amphorai, plates, kantharoi, open vessels, and unguentaria were sold in shops in Sardis. Almost 40 mold fragments were found in Sardis, which is strong evidence for a local manufacture. Most of them were found in the sector HOB (House of Bronzes).

${ }^{7}$ R. Dinç indicates in his dissertation that tumuli are found in clusters. Accordingly he named groups with letters, s. Dinç 1993, $5-6$.
} 


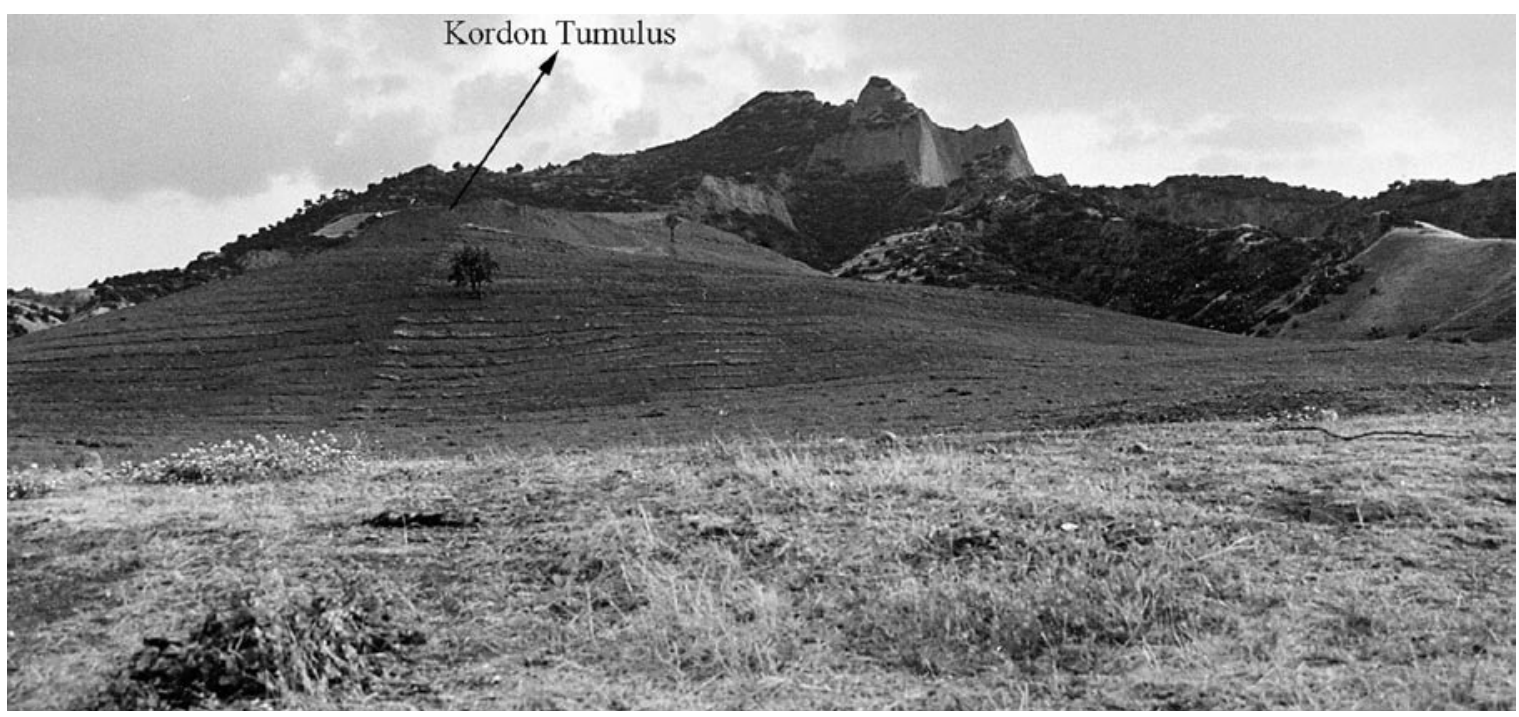

1 Kordon Tumulus, view from the north
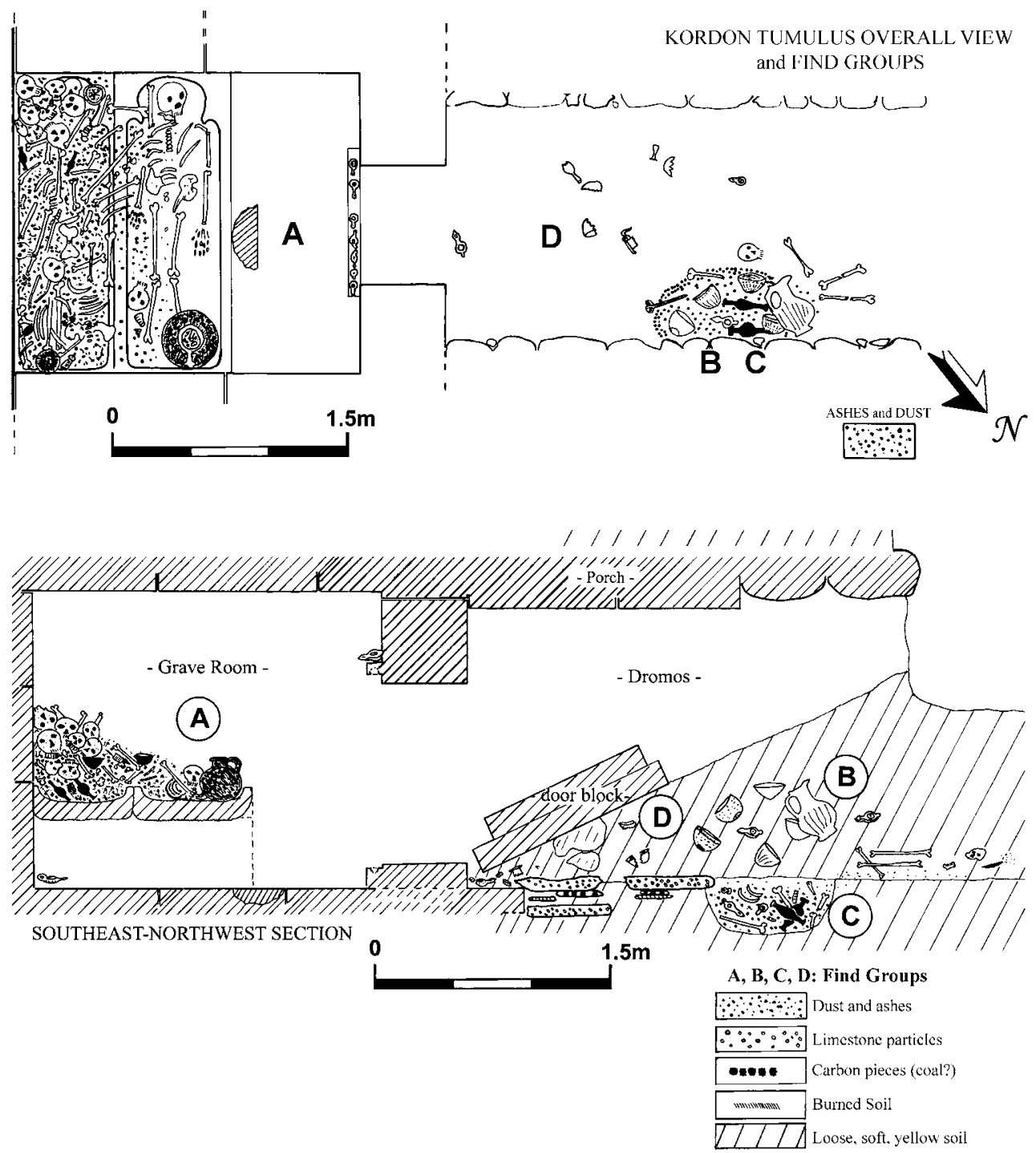

2. 3 Overview of the Kordon Tumulus and the southeast-northwestern section 


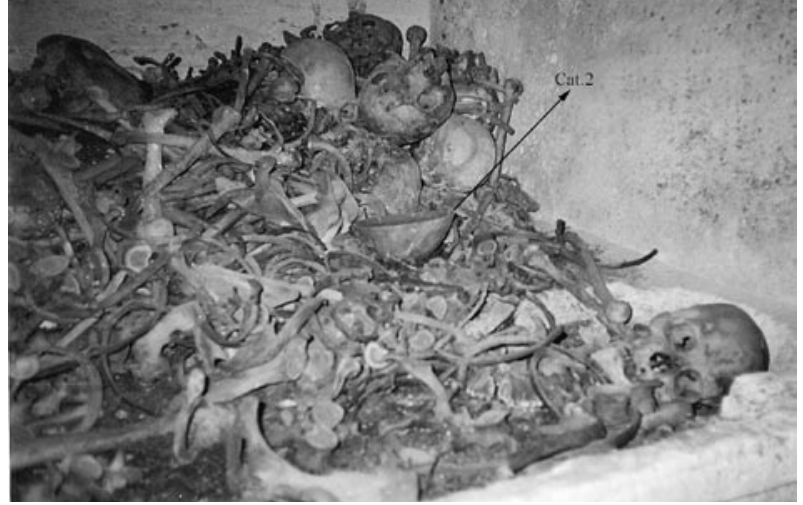

4 Skeletons on the kline (head end)

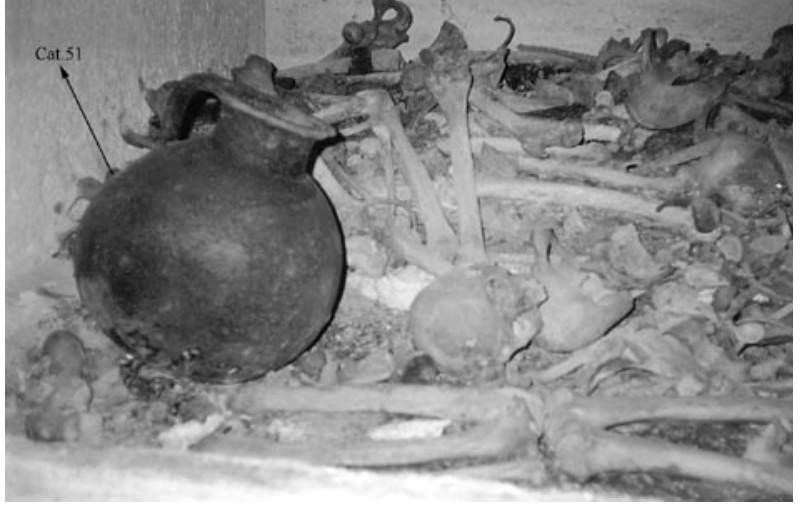

5 Skeletons on the kline (foot end)

As hellenistic pottery of the 2nd century often derives from mixed layers ${ }^{8}$, its classification is not based on a solid structure. Therefore the tomb at Kordon, which is mostly dated to the 2nd century BC, offered the chance to judge the pottery within its context, which was the categorized in the following four groups (figs. 2. 3):

Group A: Finds from inside the grave chamber, dating 125-100 BC.

Group B: Finds from in front of the northeast wall of the dromos, dating 125-100 BC.

Group C: Finds from a bothros underneath Group B, dating 140-100 BC.

Group D: Finds scattered all around the dromos, dating 510-75 BC.

Due to the fact that the dating $150-100 \mathrm{BC}$ is commonly accepted for conical bowls, as is the last quarter of the 2nd century - 1st century $\mathrm{BC}$ for many lamps, most artifacts in this contribution can be dated to the period $125-100 \mathrm{BC}$.

\section{Group A (fig. 1-7 pl. 1-7)}

Group A consists of finds (Cat. 1-13. 51. 89-94. 97-99) which were found in the grave chamber'. The find locations are the following: the shelf of the lintel (fig. 7), underneath the kline, on top and among ca. 17-20 skeletons lying on the kline (fig. 2-6) ${ }^{10}$. In the first part of the kline the last interments could be seen, i. e. the individual and the urn vase (Cat. 51) ${ }^{11}$ at its foot end (fig. 2-6).

\footnotetext{
${ }^{8}$ Günay Tuluk 1996, 31.

${ }^{9}$ On burial traditions, s. Kurtz - Boardman 1971, 209: In some graves vessels placed near the deceased are intended to quench his thirst in the other world. Oinochoes and hydrias were also used for libations.

${ }^{10}$ For intermittent use of tumuli, s. McLauchlin 1985, 53: Although the tumulus tradition disappeared in Hellenistic times in Lydia they were frequently re-used up until the 5-6th c. AD.

${ }^{11}$ For Sardian Hellenistic Period urns, s. Hanfmann 1983, 124-125: At Sardis, the inhumation burial tradition is replaced by cremation by the end of the 2 nd c. BC. The grave rooms of the Sardis necropolis were re-opened at a later date, probably in the Hellenistic Period, and the urns were placed inside them. See Greenewalt 1979, 12-19 for a similar situation in Kordon tumulus. H. C. Butler mentions urns that he found on benches together with bones. Similar patterns were also observed at Sardes T. 77.1 tumulus. The re-used tomb T. 77 with its open door plug, scattered pavement blocks, human bones in the room, dromos and urn vase, as well as the Hellenistic and Roman gifts are evidence of secondary use. The mixture of finds at T. 77 (Sardis Exc. Inv. P 77.47; L 77.5; L 77.8) implies the late 2nd c. BC. A variety of forms (echinus bowls, moldmade bowls, pelike, lagynoid vase, fusiform unguentaria) of the 2nd-1st c. BC were found, belonging to different burials (Sardis Exc. Inv. P 77.5; P 77.21; P 77.29; P 77.19; P 77.7; P 77.9, 44-46. 48-49; P 77.8; L 77.6). In its dromos 15 pottery fragments were found from the 3rd-1st c. AD. In one corner (Sardis Exc. Inv. P 77.3; P 77.4; P 77.47; P 77.11; L 77.3. 4. 7) one crater, one pot, one fusiform unguentarium, one spherical banded unguentarium, three lamps, etc., and on a higher shelf in another corner, were found (Inv. P 77.10; L 77.2. 9. 10).
} 


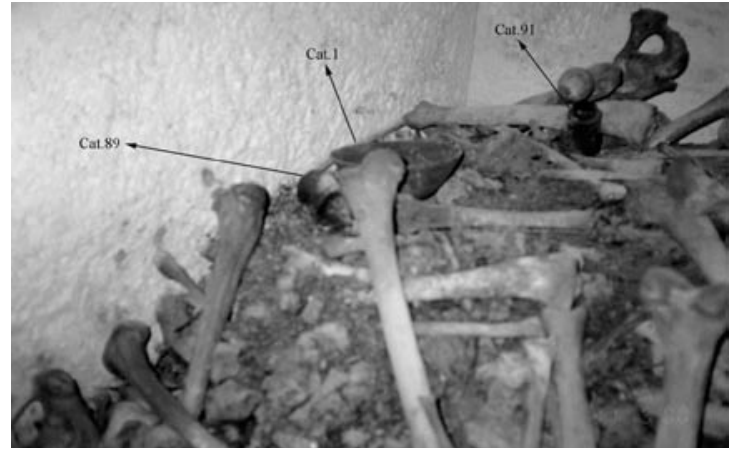

6 Skeletons on the kline (detail of the foot end)

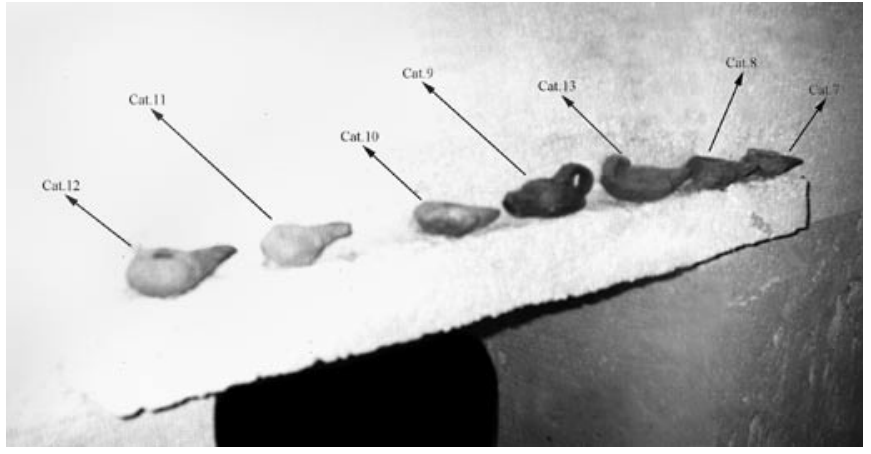

7 Lamps found in situ on the shelf

The lamps on the shelf (fig. 7) were dated to 125-100 BC, except for Cat. 11-12 (pls. 2. 6) which are datable to 300-250 BC based on similarities to published examples. Since all belong to Group A they should date to around 125-100 BC (Cat. 11-14 pls. 2. 6). The progress from wheelmade through moldmade Ephesos lamps can be observed in this series. The lamps of this group with arrow and oval head nozzles have the same counterparts at Çağlayantepe and BT. 82 Tumuli $^{12}$.

\section{Conical Bowls}

Conical Bowls of the West Slope Style like Cat. 1. 2 (pls. 1. 4) are dated at Corinth ${ }^{13}$, Samaria and at Pergamum to the 2 nd century $\mathrm{BC}^{14}$. At Sardis ${ }^{15}$ samples are close to those of Pergamum ${ }^{16}$ where conical

12 Dinç 1993, fig 97.

${ }^{13}$ For dating criteria of Hellenistic finds at Corinth, s. Edwards 1975, 189-196. 234 no. 532-541 pls. 40.55 (200-150 BC) deposit 115. Two historical points are important for the material evidence: a) destruction of Olynthos in $348 \mathrm{BC}$; b) destruction of Corinth by Mummius in $146 \mathrm{BC}$, though their exact dating is not quite clear. It is believed that there were three separate fillings in deposit 115 (a well): 1. The material from the bottom with a range from $325 / 300 \mathrm{BC}-175 / 150 \mathrm{BC}$ is attributed to the period of use. 2. A filling above, from near water level to $-4.00 \mathrm{~m}$, is regarded as representing a clean up of Mummius' destruction debris probably filled in in the early years after the foundation of the Roman colony in $44 \mathrm{BC}$. The coins from $-4.00 \mathrm{~m}$ to the bottom of the shaft, with the exception of an evidently intrusive coin of Constantius II (AD 355-361), are all from the 4th and 3rd c. BC, some with dates overlapping into 200/150 BC. There was apparently a slight mixture of Roman material in this filling, one piece being a section of a stamped Roman amphora: O. Broneer, Investigations at Corinth, 1946-1947, Hesperia 16, 1947, 233-247 pl. 57, 9. 3. A final filling of the well, between $-4.00 \mathrm{~m}$ and the top, seems to have occurred perhaps as late as the 5 th or 6 th c. AD.

${ }^{14}$ For its diffusion s. Rotroff - Oliver 2003, 38. Vessels in this style are also known from such other sites as Troy, Didyma, Gordion, Uşak, Samaria, Paphos, Dor, Tel Marisa, the Black Sea Area (Mirmeki, Mesembria, Olbia, Tanais, Kerch, Gordishe, Chersonesos). Samples are very similar to Pergamum and Sardis. These eastern forms of West Slope ceramics are rarely found on the coast of the Western Aegean.

${ }^{15}$ For conical bowls s. Rotroff - Oliver 2003, 38, Cat. 202-214. They are characterized first of all by the absence of glaze in the interior and upper exterior of the pot. The vessels are thin walled and have a brittle consistence. The fabric is harder than the general rule but contains the usual copious mica and flecks of golden mica and frequently there are voids on the surface. The glaze on the interior is often a light orange (ca. 2.5YR6/6 or 5YR7/6), the decoration is usually of the utmost simplicity - dots, dabs, and herringbone alternate with leaves. Incision is very rarely used. Fragments of about 24 shallow cups (Rotroff - Oliver 2003, 41), most of them from HOB, are decorated in an Asia Minor variety of the West Slope Style. The foot may be a low ridge or two of concentric ridges, but some cups simply have a flattened bottom. The rim is usually plain, though there is one example with an outturned rim. The glaze is generally of poor quality in black, red or mottled. The decoration is confined to the interior, in zones neatly set off and framed by concentric incised lines. The central medallion is usually a rosette or starburst with alternating red and white petals or rays. Around the wall are pickets, palmettes, garlands or dolphins. This is one of the standard drinking cups of the Hellenistic period, attested at many sites throughout the Greek world. This shape is known in Athens as early as $275-250$ BC, was most popular in the 3rd c. and became rare after about 175, but the situation may be different in the East.

${ }^{16}$ Rotroff - Oliver 2003, 41: The Pergamene cups continued to be made into the first part of the 2nd c., and D. Behr estimates that the shape may have gone on until about the middle of the century (Behr 1988, 146). A painted cup in the Eastern Sigillata A (ESA) shows that the shape was still being produced after about 150, at least in some 
bowls are dated to $125-100 \mathrm{BC}$ and the 1st century AD. These dates of 125-100 BC are in accordance with the Kordon samples. Abundance of the same kind of pottery in the Manisa and Uşak Museums can also imply their local manufacture (figs. 10 a. b). From Salihli-Gözde Tumulus a similar bowl was noted ${ }^{17}$. For conical bowls S. Rotroff suggests the 2 nd century $\mathrm{BC}^{18}$ and indicates that the West Slope ${ }^{19}$ pottery is rarely seen with moldmade bowls based on the evidence of H. C. Butler's excavations. On the other hand West Slope Style conical bowls were found side by side with moldmade bowls in the Kordon Tumulus (fig. 8).

\section{Wooden Pyxides}

Since Hellenistic wooden objects are rarely found in Western Anatolia no comparanda can be mentioned for the Kordon pyxides (Cat. 89-91 pl. 3), except some samples for the Black Sea Region. These pyxides with their downward flaring bodies, conical lids and proportions have some similarities to the pottery of the same period ${ }^{20}$.

\section{Group B (pl. 8-17)}

This context (Cat. 15-27. 29. 56. 57) was found in front of the northeast dromos wall at a depth of $0.3 \mathrm{~m}$. and measures $1 \mathrm{~m}$ in diameter. Group B (figs. 2. 3. 8) is situated on a higher level which means that the dromos was already filled with some erosion soil at this time.

The existence of identical conical bowls in Group B (Cat. 15-16 pls. 8. 11) within the Group A (Cat. 1. 2 pls. 1. 4) makes it plausible to propose same dates also for Group B, i. e. 125-100 BC.

The one handled jug, Cat. 17 (pls. 8. 12), finds a parallel in the Manisa Museum (Inv. 5317) with its painted upper part, grooved shoulder, handle, rim, and body. Cat. 18 (pls. 8. 12) is an oinochoe but no

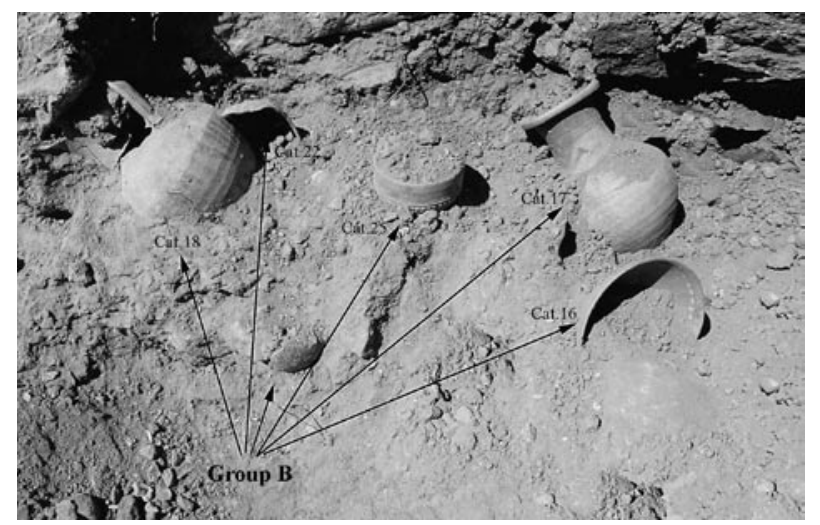

8 Group B, found inside the dromos in front of the northeastern wall equivalent can be noted in other publications. Cat. 19 (pls. 8. 12) has corresponding pieces in the Mangaltepe tumulus $^{21}$, a tomb that was also re-used in the Hellenistic period. Matching horizontal grooves on the neck

eastern centres (Robinson 1959, 27-28 no. 60 fig. 10 top pl. 3; for date of ESA s. Warner Slane 1997, 257-260. 274). See also Ziegenaus - de Luca 1968, 151. 164 nos. 333.428 pl. 54. 59: Some fragments occur in the building phases 12 and 14 of the Asklepieion dated to $125-100 \mathrm{BC}$ and the 1 st c. AD respectively, but they may be residual.

${ }^{17}$ For a bowl in the Manisa Museum, not inventoried, s. Dinç 1993, fig. 185, 20.

${ }_{18}$ Rotroff - Oliver 2003, 37-60: The West Slope technique, with simple decoration incised and painted on a glazed background, developed in Athens in the early 3rd c. The beginning of local productions is impossible to pinpoint, but it was certainly well under way by the 2 nd $\mathrm{c}$. BC.

${ }^{19}$ Rotroff - Oliver 38: S. Rotroff proposes a date for the West Slope pottery in Sardis as later than the 3rd or 2nd c. BC. The fact that West Slope vessels were rarely found together with lagynoi and moldmade bowls in the tombs excavated by the Butler expedition would tend to support such a theory. West Slope and moldmade bowls or lagynoi were found together in only three of the tombs whose contents could be reconstructed (tombs 310.407. 522), and in one of those (tomb 407) a coin of Antiochos I provides concrete evidence for a 3rd c. use. Note also the lidded jar decorated in West Slope technique on its upper body (Inv. P 1117 in Tomb 535).

${ }^{20}$ For a covered toilet vessel (pyxis) s. Rotroff 1997, no. 1253 pl. 93 (late 2nd - early 1st c. ВC) and Kotitsa 1996, passim. Б. Г. Петерс, Косторезное Дело в Античных Государствах Северного Причерноморья (= В. G. Peters, Le travail aux os dans les états antiques sur la côte septentrionale de la Mer Noire) (Moscow 1986) 68-70. 143-145 pl. 13-14, 9. 20. 21 and Н. И. СоколБскии, Деревообрабатывающее Ремесло в Античных Государствах Северного Причерноморья, СИА 1971, по. 178 pl. 30, 14.

${ }^{21}$ Manisa Museum Inv. 6074. 6075. 6077, s. Dinç 1993, fig. 213-215. 
can be found in Aiolia, Pergamum and Black Sea cities ${ }^{22}$. Cat. 20 (pls. 8. 13) is a red-glazed bowl with a possible parallel from Ephesos $^{23}$.

\section{Moldmade Bowls}

According to S. Rotroff a large percentage of the moldmade bowls from Sardis were made after about 165 $\mathrm{BC}^{24}$. The Kordon pieces with their clay specifications and glazes stand close to the Sardis material ${ }^{25}$. Some of them have dominant floral ornaments on their body while some have either animal friezes or long petals ${ }^{26}$. Cat. 21 (pls. 9. 13) is a moldmade relief bowl with long petals and dots on its body ${ }^{27}$. Cat. 22 (pls. 9. 13) is another moldmade bowl with acanthus leaves on its body, rosettes, bell shaped flowers and among those ornaments an $\oplus$ monogram. This workshop mark is sometimes seen on members of the Charioteer Group as on Cat. $56^{28}$. The moldmade bowl Cat. 23 (pls. 9. 14) has an animal frieze on its rim; similar scenes are known from Sardis, Delos and Corinth. Cat. 24 (pls. 9. 14) possesses comparanda from Sardis and Delos as well. Cat.

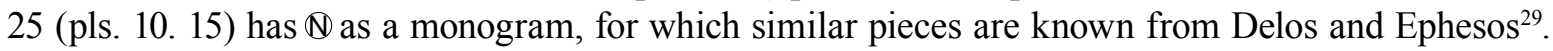

Cat. 26 (pls. 10. 15) shows a different form and clay. Its body, covered with a floral ornament, becomes narrower towards the top. It is made of a dark gray clay. Cat. 27 (pls. 10. 16) has stylized dolphins on its body. Cat. 56 (pls. 10. 17) carries an inscription. Due to some missing parts only the last three letters are

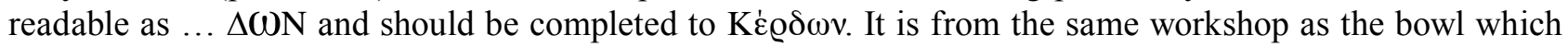
was found by H. C. Butler in tomb SW $5^{30}$. The same name is also seen on bowls in the collection of Artemis

${ }^{22}$ Rotroff - Oliver 2003, 61, s. also note 101.

${ }^{23}$ Liko 2001, 84-85. 91 Cat. 23 (2nd c. BC [?]).

${ }^{24}$ Rotroff - Oliver 2003, 94: This conclusion is based on the observation that many of the most common Sardian motifs occur in combination with linear motifs, such as the long petal or concentric semicircles. Since these linear motifs were not used on relief bowls until 175-150 BC, any bowl on which they occur must date after that time; and even when the linear motifs themselves are absent, the floral motifs with which they are associated indicate a similar date for the bowls on which they occur. The most common type of floral bowl, with alternating palm fronds and lotus petals, shares a stubby rosette with 525 , on which long petals are depicted.

${ }^{25}$ Rotroff - Oliver 2003, 104-105: The fabric of the local bowls of Sardis is most often red (2.5YR6/6, 5YR6/6, 7.5YR6/6), sometimes with a gray core, often with a friable break. It contains a good deal of mica, fine silver mica and occasional larger flakes of golden mica which is apparent when the glaze is missing. Small white inclusions are sporadic, and long narrow voids are often visible in the break. The most predominant colour in the glaze is red or reddish brown. The diameter range of the form varies between $0.09-0.20 \mathrm{~m}$, with most pieces measuring between 0.12 and $0.14 \mathrm{~m}$.

${ }^{26}$ For the typology of Sardian moldmade bowls, s. Rotroff - Oliver, 108. Floral Bowls: Floral decoration is by far the most common one at Sardis, occurring on two-thirds of the quantified samples; the percentage is about the same among the bowls found on Butler's expediton. The most popular scheme was a calyx of leaves and petals, usually with some sort of spacing motif between the tips. At Sardis, the most common type of leaf is the palm frond, which appears on close to two-thirds of the floral bowls. Frequently the palm frond is combined with a tall, pointed lotus petal. The tall, thin lotus petal is second in popularity as a motif, appearing on over a third of the examples. A variety of spacers appears between the tips of the floral motifs. The most common is the loutrophoros, which links the Sardian industry with those of Pergamon and Kyme. The rosette is second in popularity, and the following motifs occur occasionally: lotus bud, sistrum, cornucopia, triangle, mask or head, a peculiar motif that resembles a large bud set in a stylized calyx, but also recalls the Isis crown stamps of wheelmade pottery. For the long-petal bowls s. Rotroff - Oliver 2003, 122. 124: The most popular of the linear bowls was the long petal bowl, decorated with tall, round topped petals, normally ribless, running from medallion to rim. Despite stronger evidence there is still some doubt as to exactly when these bowls began to be manufactured. For many years a date of ca. $150 \mathrm{BC}$ was maintained, based on the evidence of D. Burr Thompson's Hellenistic groups and the occurrence of the bowls at Corinth. In Corinth it became evident that these bowls were being manufactured before the destruction of the city in 146 BC. For rims and medallions s. Rotroff - Oliver 2003, 127: By far the most common motifs used to decorate this zone are the egg and dart and an elongated spool motif that is best understood as a stylized form of bead and reel. The ovuli, bud, molds, rosette, simple beading, and circles are also found with some regularity.

${ }^{27}$ One moldmade bowl in the Izmir Museum Inv. 310-6-971 is very similar to Cat. 21. In the Izmir Museum there are a number of moldmade bowls similar to the Kordon pieces. Therefore a Sardian origin can be proposed.

${ }^{28}$ Rotroff - Oliver 2003, 131-132. Similar but not identical monograms are listed in: Rogl 2001, 135-136.

${ }^{29}$ Rotroff - Oliver 2003, 135-152.

${ }^{30}$ Rotroff - Oliver 2003, 203 P 1792 pl. 134 B is a floral moldmade bowl of the Charioteer Group from Tomb SW5 signed by the potter K⿺尢丶 $\delta \omega v$. 
and Martha Joukowsky ${ }^{31}$ and in the Rijksmuseum van Oudheden, Leiden ${ }^{32}$. This find supports the theory that all vases with Kerdon signature were manufactured in Sardis.

\section{Group C (figs. 2. 3. 9 pl. 18-24)}

This group was found in the northeast half of the dromos, $0.2 \mathrm{~m}$ under Group B. It was a bothros pit ${ }^{33}$, $0.4-0.5 \mathrm{~m}$ deep and $0.5 \mathrm{~m}$ in diameter, filled with ashes, bones and some finds such as Cat. 30-50, 62, $72-76,100-101$ and one anonymous corroded coin of Pergamum ${ }^{34}$.

The unguentaria are mostly dated to $125-100 \mathrm{BC}$, while one of them (Cat. 37) is doubtful in date because of its stout shape, a barely preserved black-brown glaze, thick neck, short foot and circular base ${ }^{35}$. Although in most publications this type is dated to the beginning of $3 \mathrm{rd}$ century $\mathrm{BC}$, more evidence is needed for a definite solution.

Some of the lamps belong to the Ephesos type. Prominent characteristics of this type are their hard firing and the smaller grained gray fabric. They are either gray or black glazed ${ }^{36}$. Examples of this group are imitations of corresponding metal ones with their shiny gray glaze.

Heart leaf lamps with protrusions are quite similar to the Ephesos lamps with a round shoulder ${ }^{37}$. In addition it is suggested that the discus of the early type of Ephesos lamps is not yet developed ${ }^{38}$. However, in Group C two kinds were found together and it seems probable that both types were used at the same time. Comparanda to the Ephesos lamps are known from a wider geographical context. For

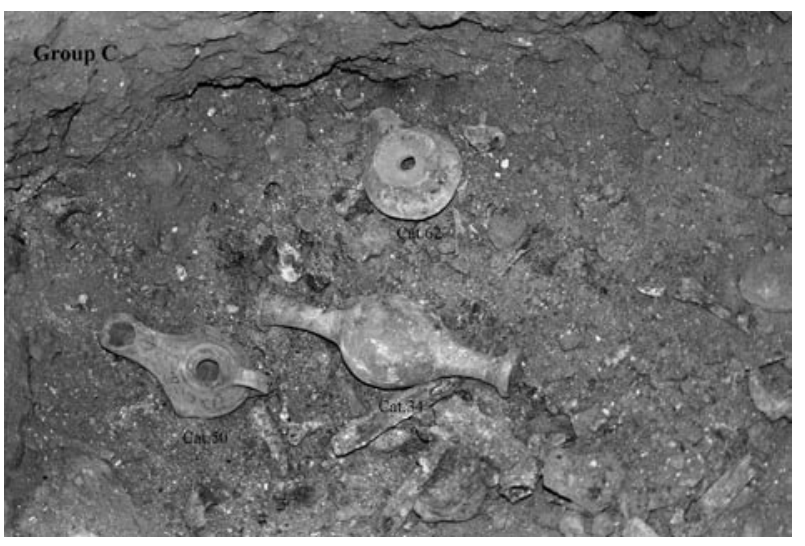

9 Group C, bothros' finds, found beneath Group B example, Cat. 43 (pls. 19. 22) is similar to pieces in the museums of Ödemiş (Inv. 1011), Izmir (Inv. 10624), Bergama (Inv. 860) and Manisa (Inv. 4151) ${ }^{39}$. The heart leaf lamp Cat. 44 (pls. 19. 22) matches a lamp in the Ephesos Museum Selçuk (Inv. 10/38/76) with its knob on one side. Cat. 45 (pls. 19. 23), also a heart leaves lamp, varies Cat. 41 (pls. 19. 22) by its grooves around the discus and plastic bands around its hollow base; on the other hand similarities of their shape imply closer dates. The Ephesos lamp Cat. 46 (pls. 19. 23) has similar ornaments to a lamp in the Ephesos Museum (Inv. 4151) ${ }^{40}$, as well as another twin in the Manisa

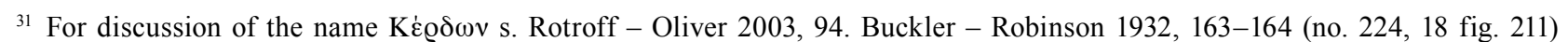
considered the name inscribed on it to be a personal name, as does Winkes 1985, 116 no. 91 for the bowl in the collection of Artemis and Martha Joukowsky. Jones 1950, however lists KEP $\Delta \Omega N$ as a variant of the stamp $x \dot{\varepsilon} \varrho \delta o \varsigma$ (profit, gain), which occurs commonly on red wares of the 1st c. AD. Either interpretation presents difficulties. If KEP $\Delta \Omega \mathrm{N}$ is a variant of $x \dot{\varepsilon} \varrho \delta \circ \varsigma$, why is it in the genitive plural? According to S. Rotroff this should imply an individual's, i. e. potter's name.

${ }^{32}$ Rogl 2005, 313-316.

${ }^{33}$ On bothroi and pyre s. Greenewalt 1978, 33 and Kurtz - Boardman 1971, 99. 164.

34 Although the coin was badly preserved on its obverse a head and on the reverse a swirling snake with a few preserved letters such as ... TAIP. could be discerned. This coin is dated to 282-133 BC, s. Sear 1979, no. 7228.

${ }^{35}$ Rotroff - Oliver 2003, 67: Most of the unguentaria are dated to the 2nd and 1st c. where large numbers of them were deposited in burials. In Sardis most fragments come from disturbed deposits and graves, but it seems that similar types were produced for a long period.

${ }^{36}$ Günay Tuluk 1996, 50: Although Ephesos lamps with oval nozzles were thought to be later in date than examples with triangular nozzles this does not seem to be the rule. Oval nozzled pieces comprise $36 \%$ of all the Ephesos lamps mentioned by Günay Tuluk 1996 and there is not considerable chronological difference among them.

37 Günay Tuluk 1996, 39. 56 pl. 11.

${ }^{38}$ Günay Tuluk 1996, 55. Like Cat. 39. 49 with a double conical body, shoulders curved out, discus with plastic band around it, long delicate nozzle, flat oval base and lack of handles with arrow nozzles is accepted as the earliest variant of the Ephesos lamps.

${ }^{39}$ Günay Tuluk 1996, 59 pls. 12 d. 13 a. 67 a. 67 c.

${ }^{40}$ Günay Tuluk 1996, pl. 67 c, no. 378, Ephesos Museum Selçuk Inv. 4151. 
Museum (Inv. 4151) which was found in the tomb of the Lintel and dates to $175 \mathrm{BC}^{41}$. Cat. 49 (pls. 20. 23) with its ornaments, lack of handles, and triangular nozzle seems very close to a lamp at the Tire Museum (Inv. 89-571) $)^{42}$.

\section{Group D (pl. 25-33)}

This group consists of pottery fragments and iron nails scattered all around the dromos (Cat. 28; 52-55; 58-61; 63-71; 78; 80-81; 82 a. c. d; 83 a; 84 a. b; 85-88; 96; 102-105). Cat. 28 (pls. 25. 29) was found in the middle of the dromos with some bones probably belonging to a disturbed inhumation. One example in the Ephesos Museum (Inv. 2551) is quite similar to Cat. 28 and dates to 300-250 BC. Another comparable piece was found in Ephesos by J. T. Wood and dates to the 2 nd century $\mathrm{BC}^{43}$. Other similar pieces are known from the Akhisar-Harmandalı Cemetery Tomb B with an unguentarium and dating to the beginning of the 3rd century BC ${ }^{44}$. But since a very similar piece was found in Group A (Cat. 11 pls. 2. 6) it can also belong to the last quarter of the 2 nd century BC. Round shoulder wheelmade lamps seem to be manufactured in a wider time $\operatorname{span}^{45}$.

Cat. 55 (pls. 25. 29), a moldmade bowl, has a loutrophoros frieze on its body. A similar decoration is known from a moldmade amphora from the Sardian tomb of the Lintel (175 BC; Sardis Exc. Inv. P59.412 $)^{46}$ and some from the Manisa Museum (Inv. 2872. 2879. 1198). Cat. 61 (pls. 26. 30) resembles Cat. 26 (pls. 10. 15, Group B) in style, therefore it seems logical to assume a date around 150 BC. Cat. 63 (pls. 26. 31), an incurved rim bowl, is seen commonly in all phases of the Hellenistic Period. Due to its red slip it can be dated to the 3rd century through to the middle of the 2nd century BC onwards.

Some of the pitcher rims and necks have slips on their surface while some are plain. A precise date could not be assigned to them because of their circulation over a longer time period ${ }^{47}$.

Similar ivy leaves or club motifs on the rim of the moldmade bowl Cat. 81 (pls. 27. 32) are also seen on Cat. 25 (pls. 10. 15, Group B) which is from the middle of the 2nd century BC. Cat. 86 (pls. 28. 33), an Ephesos type lamp, has tiny pointed leaves in tile formation on its shoulder. The same decoration is seen on a sample in the Ephesos Museum (Inv. 134/68/89) of 125-100 BC ${ }^{48}$. The wheelmade archaic lamp Cat. 87 (pls. 28. 33) is the earliest find from the Kordon Tumulus. It derives from the first burial phase, i. e. the Lydian Period, at the beginning of the 5th century BC. Cat. 88 (pls. 28. 33) has an unclear head figure (Silenos?) in relief on its nose. Similar ornaments are known on some other examples in the form of Dionysiac characters and floral ornaments ${ }^{49}$.

Iron nails (Cat. 96 pl. 28) were recovered from pit Group C and different parts of the dromos. They are seen over a wider period. Equivalents are known from a tumulus excavated by A. Choisy in 1876 and the BT63.2 Tomb in the Bintepeler region ${ }^{50}$.

A spherical fired terracotta object (Cat. 102 pl. 28) was found in the dromos. Comparable pieces are known from several tombs in Eastern Greece but the exact meaning of these has not yet been established ${ }^{51}$.

\footnotetext{
${ }^{41}$ Sardis Expedition Inv. PC L 5980, 1851.

${ }^{42}$ Günay Tuluk 1996, pl. 10 d, no. 60 ; pl. 65 g, no. 367.

${ }^{43}$ Tuluk 1996, 28-29 Cat. 22 pl. 3 b.

${ }^{44}$ Günay Tuluk 1996, 26, Manisa Museum Inv. 4671 (pl. 60 c); 4672 (pl. 60 1); 4679 (pl. 60 k).

45 Günay Tuluk 1996, 30.

46 Hanfmann 1983, 114.

${ }^{47}$ For similar examples from Clazomenae s. İ. Irk Hasdağlı, Klazomenai HBP Alanında Açığa Çıkarılan 10B, 10C Kuyularının Statigrafisi ve Malzemesinin Değerlendirilmesi (unpublished diploma thesis Ege University Izmir 1997).

48 Günay Tuluk 1996, 58 pl. 14 b, no. 78.

49 Günay Tuluk 1996, 67.

${ }^{50}$ Dinç 1993, 71. 125, BT 63.2 tomb; nails sometimes used to curse tomb robbers, s. Kurtz - Boardman 1971, 217.

${ }^{51}$ Kurtz - Boardman 1971, 215: Food was also laid in offering pits (animal bones, sea shells, eggs, nuts, etc.). In bothroi stone eggs and clay animal figurines also were found.
} 

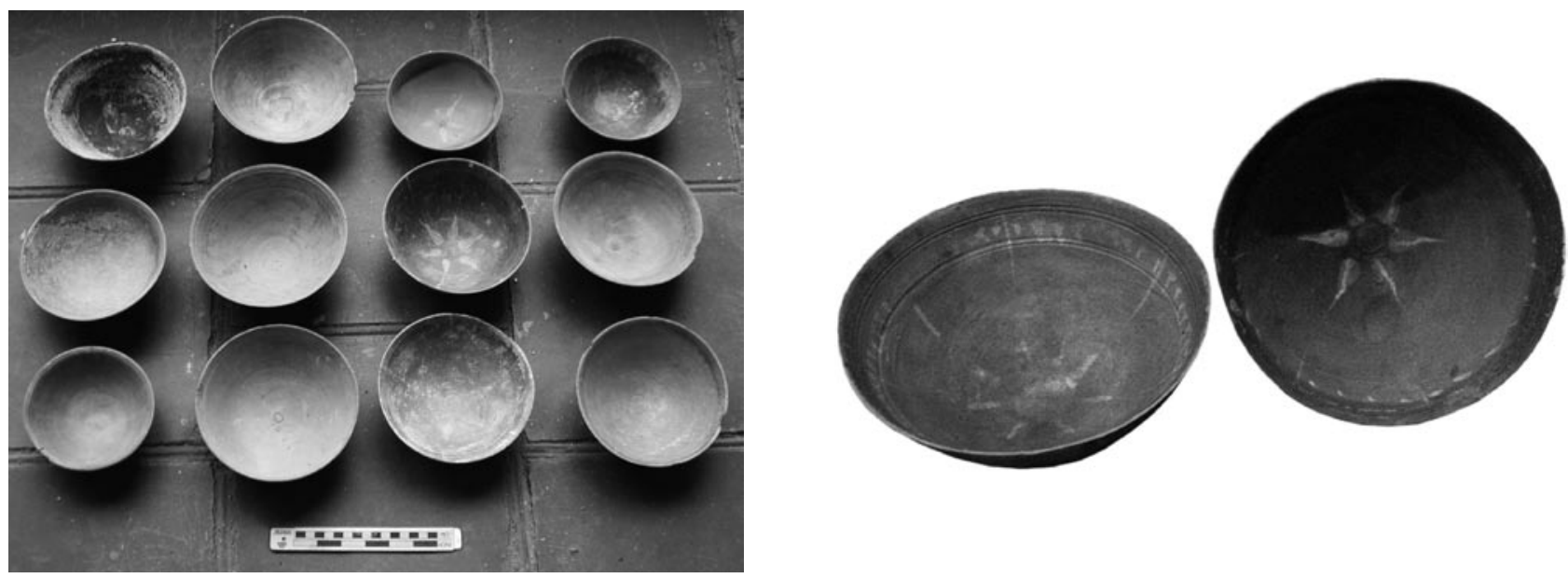

$10 \mathrm{a}$. b Conical bowls, Museums of Manisa and Uşak

\section{Conclusion}

Due to the find groups A-D, the burial phases of the Kordon tumulus become clear. This Lydian tomb was first used at the beginning of the 5th century BC and sporadically re-used in the Hellenistic period, mainly in the years between 125-100 BC.

Although several publications suggest contradictory dates for some of the artifacts (for example Cat. 37 pls. 18. 21) the majority of the pieces were found in context with other finds that can be securely dated between 125-100 BC. If the beginning of the 1st century BC is also applicable to the urn vase (Cat. 51 figs. 2. 6 pls. 2. 7) this date would imply the final use of the tumulus.

A majority of the finds consists of drinking cups, followed by lamps and unguentaria ${ }^{52}$. Most publications date conical bowls to the 2 nd century $\mathrm{BC}$ or more precisely to the middle of the 2 nd century $\mathrm{BC}$. Their existence in Group A, B and D indicates that they were commonly used in the years between 125-100 BC or a bit later.

Group B and C were not found directly related to a burial. The finds belonging to the previously mentioned groups could represent ritual gifts or even be part of a former, non related burial. Burial customs and rituals in Lydian tumuli are not known, except for the evidence in the Basmacitepe tumulus ${ }^{53}$.

Although most Lydian tumuli were re-used in Hellenistic times, no precise time span is known as to when this practice was most frequent, and requires further research ${ }^{54}$.

${ }^{52}$ Günay Tuluk 1996, 66: Of 436 lamps 17\% are wheelmade, 18\% heart shaped, 3\% in Cnidian Type and 62\% Ephesos lamps, which were often copied. Kurtz - Boardman 1971, 211: With the end of the Classical Period an increase in numbers of lamps in graves can be observed. Maybe burials were conducted at night time or the lamps should light the way into the after life. McLauchlin 1985, 153, 155: Wares found in graves are mostly related to dining (fig 38). Most common are drinking bowls. Of 250 wares, more than 100 are amphorai, hydriai, jugs, craters, oinochoes and skyphoi. The second large group are unguentaria and cosmetic jars.

${ }^{53}$ Mc Lauchlin 1985, 19: There is no evidence that the dromos was a ritual architectural element nor it was used by the living to perform periodic rites at the tomb complex after the burial had taken place. Dinç 1993, 247: But in some dromoi it is clear that some burial rites took place and a special meal was consumed here by attendants. $6.3 \mathrm{~m}$ away from the entrance to the Aktepe Tumulus on the floor of the dromos a firing place and cooking pot fragments were found. Some evidence reveals incontrovertibly that funeral dinners took place also in some dromoi. At BT62.4 tomb bones of a puppy were found with the charcoal (late 5th c. BC). For burial practices and rituals s. Kurtz - Boardman 1971, 143. 145-147. 149-150. 205. Besides the previously mentioned funeral gifts water, wine, fruits and honey, etc. were also laid out for the deceased.

${ }^{54}$ Green 1990, 529. It is mentioned in historical sources that the region was reached by the Aristonicus Riots around 125 BC. 


\section{Catalogue $^{55}$}

\section{Group A}

Cat. 1

Conical bowl

pls. 1.4

Date and place of find: 31.05 .2000 , inside room, on kline.

H: $0.067 \mathrm{~m}$; Dm: $0.165 \mathrm{~m}$.

Clay: Fine (10YR6/2 light brownish gray).

Surface: Brown dipped (5YR4/1 dark gray).

Complete. One groove at rim inside, one in the middle and one around the tondo. Outside, on the body tiny groups of grooves. Groove around convex base. 8-petaled flower rosette at tondo, inside at rim white garland (7.5YR8/4 pink) between two bands. West Slope Style.

Cf.: Although with black glaze, Edwards 1975, 55 no. 532-541 pl. 40 (200-150 BC); Rotroff - Oliver 2003, 38-41 pl. 30-32 nos. 204. 206-208. 210. 212; Schäfer 1968, 45-63. 145-147; G. de Luca - W. Radt, Sondagen im Fundament des großen Altars, PF 12 (Berlin - New York 1999) 82-90 pl. 12-14; E. Böhringer - F. Krauss, Das Temenos für den Herrscherkult, AvP 9 (Berlin - Leipzig 1937) pl. 57g, 1-3; pl. 59c; Mitsopoulos-Leon 1991, 32-74; Gassner 1997, 59-69; Rotroff 1997, 110 no. 113.

Date: $125-100$ BC.

\section{Cat. 2}

pls. 1.4

Conical bowl

Date and place of find: 31.05 .2000 , inside room, on kline.

H: $0.074 \mathrm{~m}$; Dm: $0.169 \mathrm{~m}$.

Clay: Fine (10YR6/2 light brownish gray).

Surface: Inside completely and outside around the rim brown dip slip (5YR4/1 dark gray). Additional white painting at tondo (7.5YR8/4 pink). 7-petaled flower at the tondo.

Complete. Double grooves inside the rim and tiny one at the tondo. Grooved convex base. West Slope Style.

Cf.: s. also Cat. 1; Edwards 1975, no. 532-541 pl. 40, 55; Crowfoot - Crowfoot - Kenyon 1957, fig. 53 no. 1 Q 4666; Anderson 1954, pl. 11 no. 244-247.

Date: $125-100$ BC.

\section{Cat. 3}

pls. 1.5

\section{Unguentarium}

Date and place of find: 31.05 . 2000, inside room, on kline.

H: $0.142 \mathrm{~m}$; Dm: $0.028 \mathrm{~m}$; Dm at base: $0.027 \mathrm{~m}$.

Clay: Fine (5YR6/6 reddish yellow).

Surface: Light brown slip on the body (7.5YR7/6 reddish yellow) with parallel dark brown bands (7.5YR5/4 brown).

One part of base is missing. Overhanging rim, thick neck, slight curved shoulder, short foot, plumb body, circular base.

Cf.: s. Cat. 33; Knigge 1976, pl. 68 no. 379, 1. F; Greenewalt 1979, fig. 16 (150-100 BC); Rotroff - Oliver 2003, 69 pl. 44 no. 257.

Date: $125-100$ BC.
Cat. 4

pls. 1.5 Unguentarium

Date and place of find: 31 . 05. 2000, inside room, on kline. H: $0.16 \mathrm{~m}$; Dm: $0.028 \mathrm{~m}$; Dm at base: $0.024 \mathrm{~m}$.

Clay: 2.5YR6/6 light red.

Surface: Plain, light red surface (7.5YR6/6 reddish yellow). Complete. Outturned rim, tall thin neck, body narrowing to the base, short foot, conical base.

Cf.: Knigge 1976, 167 pl. 71 no. 403, 2 (75-50 BC).

Date: $125-100$ BC.

Cat. 5

pls. 1.5

Unguentarium

Date and place of find: 31.05 .2000 , inside room, on kline. H: $0.165 \mathrm{~m}$; Dm: $0.026 \mathrm{~m}$; Dm at base: $0.025 \mathrm{~m}$.

Clay: Fine (7.5YR5/6 strong brown).

Surface: Plain, dark brown surface (10YR5/4 yellowish brown).

Complete. Outturned rim, long, slim neck, slightly curved shoulder, body narrowing to base, small base.

Cf.: Knigge 1976, pl. 69 no. 388; Kotitsa 1998, pl. 65 no. 114; Gürler 1994, fig. 39 pl. 29 no. 137; Rotroff - Oliver 2003, pl. 44 no. 259 ( 2 nd c. or 1st half of 1st c. BC); Anderson Stojanovic 1992, pls. 67.178 nos. 566. 568; Metzger 1994, 72 pls. 34. 35 (150-100 BC).

Date: $125-100$ BC.

Cat. 6

pls. 1.5

Unguentarium

Date and place of find: 31 . 05. 2000, inside room, on kline.

H: $0.134 \mathrm{~m}$; Dm: $0.026 \mathrm{~m}$; Dm at base: $0.022 \mathrm{~m}$.

Clay: Less micaceous, sandy (10YR5/3 brown).

Surface: Poorly preserved gray slip (2.5YR6/2 light brownish gray).

Complete. Outturned thick rim, narrow neck, lightly curved shoulder, short thick circular base.

Cf.: Knigge 1976, pl. 68 nos. 369. 377; Vessberg - Westholm 1956, fig. 24 no. 23 ; Rotroff - Oliver 2003, 69 pl. 44 no. 257 $(300 / 250 \mathrm{BC}-3 \mathrm{rd}$ or $2 \mathrm{nd} \mathrm{c.} \mathrm{BC})$.

Date: $125-100 \mathrm{BC}$.

Cat. 7

pls. 1.5

Ephesos lamp

Date and place of find: 31. 05. 2000, inside room.

Pres. L: 0.106 m; W: 0.06 m; H: 0.033 m; Dm discus gap: $0.013 \mathrm{~m}$.

Clay: Fine (7.5YR5/2 brown).

Surface: Shiny metallic gray slip (7.5YRN4/ dark gray).

Nozzle and handle partly preserved. Double conical body, collar around concave discus, three holes. Smooth surface, thin long nozzle. Plain oval base. On the nozzle and the shoulder relief dots between palmettes and spirals.

\footnotetext{
${ }_{55}$ Additional used abbrevations in the catalogue are the following ones: Dm = Diameter; Exc. = Excavation; $($ pres. $) \mathrm{H}=$
} (preserved) Height; L = Length; $\mathrm{W}=$ Width. 
Cf.: Günay Tuluk 1996, fig. 30 b no. 306; Kassab 1988, nos. 294. 313 (125/100 BC-1st c. AD); Hayes 1980, no. 56 (1st c. BC); Oziol 1977, pl. 57 no. 135; Hellström 1965, pl. 23 no. 38; Chrzanovski - Zhuravlev 1998, 47 no. 12 (125-75 BC); Howland 1958, 166-169, pl. 49 no. 658 (125 BC-25 AD); Meriç 2002, 128 pl. 74, L 23 (0-25 AD).

Date: $125-100$ BC.

\section{Cat. 8}

pls. 1.6

Ephesos lamp

Date and place of find: 31. 05. 2000, inside room.

Pres. L: 0.122 m; W: 0.065 m; H: 0.035 m. Dm discus gap: $0.012 \mathrm{~m}$.

Clay: Micaceous (10YR5/2 grayish brown).

Surface: Gray black glaze (7.5YRN3/ very dark gray).

Complete. Double conical body. Double grooved handle. Shallow concave discus. Round tip, smoothed long nozzle. On shoulder square flowers, on nozzle triangular grouped relief dots.

Cf.: s. also Cat. 7. Günay Tuluk 1996, fig. 14 a, no. 83; Hayes 1980, nos. 55. 56 (end of 2nd-1st c. BC); Gürler 1994, fig. 49 pl. 39 nos. 181. 185 (1st c. BC); Meriç 2002, 128 pl. 74, L 19 (0-25 AD); Ladstätter 2005, K 275; Gassner 1997, 193 no. 796 pl. 63 (125 BC-50 AD).

Date: $125-100 \mathrm{BC}$.

\section{Cat. 9}

pls. 1. 6

Ephesos lamp

Date and place of find: 31. 05. 2000, inside room.

Pres. L: $0.11 \mathrm{~m}$; W: 0.0625 m; H: 0.035 m; Dm discus gap: $0.014 \mathrm{~m}$.

Clay: Fine (7.5YR5/2 brown).

Surface: Gray black glaze (7.5YRN4/dark gray).

Long nozzle with missing round tip. Double conical bowl. Double grooved handle. Collar around small discus gap. Base of double plastic rings and one dot in the centre. Waves on shoulder; palmette on nozzle.

Cf.: Günay Tuluk 1996, fig. 12 a, no. 72; Bruneau 1965, 67 pl. 16 no. 2879; Zapheiropoulos - Chatzedakis 1994, pl. 187, $\beta 14952$ (125-100 BC).

Date: $125-100$ BC.

\section{Cat. 10}

pls. 1. 6

Heart shape lamp

Date and place of find: 31. 05. 2000, inside room.

Pres. L: 0.095 m; W: 0.055 m; H: 0.031 m; Dm discus gap: $0.017 \mathrm{~m}$.

Clay: Fine (5YR5/3 reddish brown).

Surface: Shiny, metallic glaze (2.5YRN4/ dark gray).

Complete. Double conical body. A knob on one side. Long plain nozzle. Base of round plastic band and dot in the centre.

Cf.: Günay Tuluk 1996, 41 pl. 9 d, no. 55; Bruneau 1965, 27 pl. 5 nos. 288. 294.

Date: $125-100$ BC.

Cat. 11

pls. 2. 6

Wheelmade lamp

Date and place of find: 31. 05. 2000, inside room.

Pres. L: 0.088 m; W: 0.053 m; H: 0.0325 m; Dm discus gap: $0.017 \mathrm{~m}$.
Clay: Fine (2.5YR6/6 light red).

Surface: Redbrown glaze (5YR3/1 very dark gray).

Complete. Globular body, tiny groove around discus, a knob on one side, arrow shaped nozzle, concentric plastic rings at base.

Cf.: Günay Tuluk 1996, pl. 3 b, no. 22 (1st half of 3rd c. BC); Howland 1958, 118 pl. 44 no. 500 (late 2nd c. - 2nd quarter of 1st c. BC).

Date: $125-100$ BC.

\section{Cat. 12}

pls. 2.6

Wheelmade lamp

Date and place of find: 31. 05. 2000, inside room.

Pres. L: 0.089 m; W: 0.059 m; H: 0.0305 m; Dm discus gap: $0.02 \mathrm{~m}$.

Clay: Fine, less micaceous (2.5YR6/6 light red).

Surface: Red slip, (2.5YR5/6 red).

Complete. Globular body, tiny groove around wide discus, small haloding knob on one side. Long nozzle with burned tip. Base with double concentric plastic bands.

Cf.: Günay Tuluk 1996, pl. 3 a, no. 19 (end of 3rd - early 2nd c.); Oziol 1977, no. 69 (end of 3rd c. - 125 BC); Kassab 1988, nos. 185. 192; Jones 1950, fig. 93 no. 5 (early 3rd c. BC); Howland 1958, pl. 44 no. 498 (early 1st c. BC); Bruneau 1965,

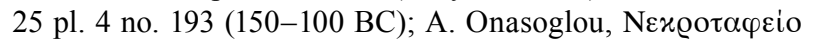

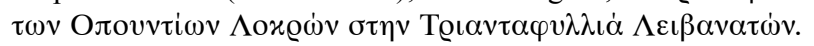

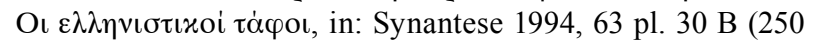
$\mathrm{BC})$.

Date: $125-100$ BC.

\section{Cat. 13}

pl. 2

Ephesos lamp

Date and place of find: 31. 05. 2000, inside room.

Pres. L: 0.125 m; W: 0.071 m; H: 0.031 m; Dm discus gap: $0.013 \mathrm{~m}$.

Clay: Micaceous (5YR6/1 gray).

Surface: Shiny gray glaze (2.5YRN4/ dark gray).

Complete. Double conical body. Collar around the concave discus. Flat, short nozzle with arrow tip. One plastic band around base. Garland of leaves on shoulder tied with a band at beginning of nozzle. One dot on each side of the band.

Cf.: Günay Tuluk 1996, pl. 25 b, no. 154; Hellström 1965, pl. 23 no. 38 (150-100 BC); Gürler 1994, fig. 48 pl. 38 no. 178 (1st c. BC); Kassab Tezgör - Sezer 1995, no. 300 (125-100 BC); Hayes 1980, no. 55; Jones 1950, no. 47 (2nd-1st c. $\mathrm{BC})$.

Date: $125-100$ BC.

\section{Cat. 14}

pls. 2. 6

Ephesos lamp

Date and place of find: 31. 05. 2000, inside room, under kline.

Pres. L: 0.13,3 m; W: 0.07 m; H: 0.032 m; Dm discus gap: $0.014 \mathrm{~m}$.

Clay: Micaceous (5YR6/1 gray).

Surface: Shiny, dark gray glaze (7.5YRN4/ dark gray).

Complete. Double conical body, shallow discus. Double grooved handle. Flat, circular pointed nozzle. Circular, flat base. Large ovuli on shoulder, ropes between rosettes on the nozzle channel.

Cf.: Günay Tuluk 1996, pl. 25 b, no. 154; Hellström 1965, pl. 
23 no. 38 (150-0 BC); Gürler 1994, fig. 48 pl. 38 no. 178 (1st c. BC); Kassab Tezgör - Sezer 1995, no. 294 (125-100 BC); Hayes 1980, no. 56 (1st c. BC); Jones 1950, no. 47 (2nd-1st c. $\mathrm{BC})$; Howland 1958, 166 pl. 49 no. 653 (125 BC-25 AD).

Date: $125-100$ BC.

\section{Cat. 51}

pls. 2.7

One handled urn (stewpot)

Date and place of find: 31.05 .2000 , inside room.

H: $0.353 \mathrm{~m}$; Dm at rim: $0.158 \mathrm{~m}$.

Clay: Sandy, gritty and coarse (5YR5/3 reddish brown). Surface: 5YR4/1 dark gray.

Complete except small hole near bottom. Everted and inwardsloping rim. Globular body. One, oval profiled handle.

Cf.: Anderson Stojanovic 1992, pl. 131 no. 1127 (probably 1st c. $\mathrm{BC}-1$ st c. AD).

Date: ca.100 BC.

\section{Cat. 89}

Wooden pyxis with conical lid

Date and place of find: 31. 05. 2000, inside room, on kline. Body pres. H: 0.065 m; Dm at rim: 0.035 m; Dm at base: 0.05 $\mathrm{m}$; Wall thickness: $0.006 \mathrm{~m}$. Inside depth: $0.045 \mathrm{~m}$; pres. $\mathrm{H}$ lid: $0.047 \mathrm{~m}$; inner H: $0.015 \mathrm{~m}$; Dm $0.055 \mathrm{~m}$.

Flat base missing. Several grooves on lid fitting with the rim of the pyxis. Four grooves on the upper and lower part of the body. On the lid and the lower part of the body parallel horizontal grooves with vertical notches inside. Hand drill marks inside the body and under the cap.

Cf.: Rotroff 1997, no. 1253 pl. 93 (pottery pyxis) (late 2nd - early 1 st c. BC).

Date: $125-100$ BC.

\section{Cat. 90}

Wooden pyxis with conical lid

Date and place of find: 31. 05. 2000, inside room, upper kline.

Pres. H: $0.082 \mathrm{~m}$; Dm at rim: $0.033 \mathrm{~m}$; Dm at base: $0.052 \mathrm{~m}$; Inside depth: $0.056 \mathrm{~m}$; Wall thickness: $0.006 \mathrm{~m}$; pres. $\mathrm{H}$ lid: $0.029 \mathrm{~m}$; Inside depth: $0.01 \mathrm{~cm}$; Dm: $0.054 \mathrm{~m}$.

Fragments. Double grooves on conical lid. Downward flaring cylindric body. A couple of grooves on the upper and lower body, one groove in the centre. Parallel hand drill marks inside body and lid. Flat base.

Date: $125-100$ BC.

\section{Cat. 91}

pl. 3

Wooden pyxis with conical lid

Date and place of find: 31.05 .2000 , inside room, on kline.

Pres. H: $0.076 \mathrm{~m}$; Dm at rim: $0.022 \mathrm{~m}$; Dm at base: $0.048 \mathrm{~m}$; Depth: $0.051 \mathrm{~m}$; Wall thickness: $0.0065 \mathrm{~m}$.

Downwards flaring, cylindrical body. Double grooves on upper, middle and lower body. Parallel handdrill marks inside the body and the lid. Flat bottom.

Date: $125-100$ BC.
Cat. 92

Bone comb

Date and place of find: 31. 05. 2000, inside room, upper kline.

Pres. H: $0.085 \mathrm{~m}$; W: $0.063 \mathrm{~m}$; Thickness: $0.004 \mathrm{~m}$.

Double side comb with thin and thick teeth on either sides. Concentric circles with central dot and zigzag ornaments on body.

Date: $150-100$ BC.

Cat. 93

pl. 3

Wooden fragments

Date and place of find: 31. 05. 2000, inside room, upper kline.

$0.20 \times 0.05 \times 0.04 \mathrm{~m}$. Some are joined to each other.

Date: $150-100 \mathrm{BC}$.

Cat. 94

Braiding (rope?)

Date and place of find: 31. 05. 2000, inside room, upper kline.

Pres. H: ca. $0.03 \mathrm{~m}$.

Three knitted strings preserved, probably belonging to a basket or robe, etc.

Date: $125-100$ BC.

Cat. 97

Spherical faience pendants

Date and place of find: 31. 05. 2000, inside room, upper kline.

Dm: $0.007 \mathrm{~m}$.

Badly preserved. Golden plated, white-cream faience, beadlike spheres. Hollow at one side. Nine items were found.

Date: $125-100$ BC

Cat. 98

Bead of the evil eye

Date and place of find: 31. 05. 2000, inside room, upper kline.

Dm: $0.008 \mathrm{~m}$.

Blue and white glass. Eyes with black pupils.

Date: $125-100$ BC.

Cat. 99

Omen stone (?)

Date and place of find: 31.05 .2000 , inside room, on kline, in wooden pyxis Cat. 89.

Dm: $0.014 \mathrm{~m}$.

Transparent yellow glass. Convex on top, flat underside.

Date: $125-100$ BC. 


\section{Group B}

\section{Cat. 15}

Conical bowl

Date and place of find: 05. 06. 2000, dromos.

H: $0.0635 \mathrm{~m}$; Dm at rim: $0.175 \mathrm{~m}$.

Clay: Micaceous (2.5YR6/8 light red).

Surface: Red glaze on inside and outside of rim (2.5YR6/8 light red).

Complete, small cracks on the rim. Three grooves on the inside. White dots (5YR8/1 white) between 8-petaled rosettes at the tondo and grooves around rim. Concave base surrounded by one groove. West Slope Style.

Cf.: s. Cat. 1; Edwards 1975, no. 532-541 pls. 40.55 (200-150

BC); Anderson 1954, nos. 234. 236 pl. 11; Waagé 1941, fig. 3 no. 55,12 . 13 (225-150 BC); Rotroff - Oliver 2003, 38-41 pl. $30-32$.

Date: $125-100 \mathrm{BC}$

\section{Cat. 16}

pls. 8. 11

Conical bowl

Date and place of find: 05. 06. 2000, dromos.

$\mathrm{H}: 0.055 \mathrm{~m}$; Dm at rim: $0.158 \mathrm{~m}$.

Clay: 2.5YR6/6 light red.

Surface: Inside the outside of the rim red glaze (2.5YR5/4 reddish brown). 5-petaled rosettes at the tondo and dots between grooves around rim in white painting (5YR 8/1 white).

Complete. Three grooves inside the rim. Double grooves around the convex base. West Slope Style.

Cf.: s. also Cat. 1. 2. 15; Edwards 1975, no. 532-541 pls. 40. 55; Anderson 1954, nos. 234. 236 pl. 11; unpublished parallels are known from the Museums of Manisa and Uşak.

Date: $125-100$ BC.

\section{Cat. 17}

pls. 8. 12

Pitcher

Date and place of find: 05. 06. 2000, dromos.

H: $0.243 \mathrm{~m}$; Dm at rim: $0.107 \mathrm{~m}$; Dm at base: $0.075 \mathrm{~m}$.

Clay: Less micaceous (5YR6/6 reddish yellow).

Surface: Rim to shoulder brown, dipped glaze (2.5YR5/4 reddish brown). Plain body (7.5YR7/4 pink).

Complete. Flaring ring foot, globular body, outturned lip, from long neck to shoulder strap handle. A couple of grooves on the neck, one on the shoulder.

Cf.: Rotroff - Oliver 2003, 64 pl. 35 no. 227.

Date: $125-100$ BC.

\section{Cat. 18}

pls. 8. 12

Oinochoe

Date and place of find: 05. 06. 2000, dromos.

H: $0.266 \mathrm{~m}$; Dm at rim: $0.13 \mathrm{~m}$; Dm at base: $0.111 \mathrm{~m}$.

Clay: Less micaceous (5YR6/6 reddish yellow).

Surface: Upper half of body dipped in dark brown glaze (10YR4/2 dark grayish brown). Unglazed lower body (10YR7/4 pale brown).

Complete. Globular body, long neck, one handle from neck to shoulder, trefoil mouth, flaring ring foot.

Date: $125-100$ BC.
Cat. 19

Pitcher

Date and place of find: 05. 06. 2000, dromos.

H: $0.316 \mathrm{~m}$; Dm at rim: $0.122 \mathrm{~m}$; Dm at base: $0.101 \mathrm{~m}$.

Clay: Fine, less micaceous (2.5YR6/6 light red).

Surface: Rim to shoulder dark brown, dipped glaze (10YR4/2 dark grayish brown). Unglazed lower body (7.5YR7/6 reddish yellow)

Flaring ring foot. Ovoid body. Outturned rim. Strap handle from shoulder to rim. Outturned rim.

Cf.: Rotroff - Oliver 2003, pl. 140 P 179 (2nd c. - middle of 1st c. BC).

Date: $125-100$ BC.

Cat. 20

pls. 8. 13

Bowl

Date and place of find: 05. 06. 2000, dromos.

H: $0.062 \mathrm{~m}$; Dm at rim: $0.112 \mathrm{~m}$.

Clay: Less micaceous, small particles (2.5YR6/6 light red). Surface: Inside and outside the rim dipped, red glaze (10R $5 / 8$ red).

Complete, with cracks. Steep side walls, ring base.

Cf.: Liko 2001, 84-85. 91 no. 23 (2nd c. BC [?]); MeyerSchlichtmann 1988, 77-79 pl. 39, B2. B4 (150-100 BC); B6 (100-75 BC).

Date: $125-100$ BC.

\section{Cat. 21}

pls. 9.13

Moldmade relief bowl

Date and place of find: 05. 06. 2000, dromos.

$\mathrm{H}: 0.073 \mathrm{~m}$; Dm at rim: $0.099 \mathrm{~m}$.

Clay: Fine, less micaceous (5YR7/6 reddish yellow).

Surface: Redbrown glaze (2.5YR5/4 reddish brown).

Rim zone: Frieze of circles. Main zone: long petals separated by rows of beads. Base medallion: 12-petaled rosette.

Cf.: Gürler 1994, fig. 29 pl. 20 (mid 2nd c. BC); Hellström 1965, pl. 11 nos. 142. 145. 146 (mid 2nd c. BC); Jones 1950, fig. 130 no. 163 (2nd c. BC); Siebert 1978, pl. 85 no. 4; Courby 1922, fig. 80 no. 4; Rotroff - Oliver 2003, 94 pl. 72, 433. 450. 621; Greenewalt 1979, 30 no. 60; Hanfmann - Waldbaum 1975, 116 fig. 279 (150-100 BC); Zapheiropoulos - Chatzedakis 1994, 240 pl. 184, B 14739. B 14773 (end of 2nd c. - beginning of 1st c. BC); Laumonier 1977, 53-55 pls. 11.15 , no. 4834

Date: $125-100$ BC.

Cat. 22

pls. 9.13

Moldmade relief bowl

Date and place of find: 05. 06. 2000, dromos.

H: $0.075 \mathrm{~m}$; Dm at rim: $0.125 \mathrm{~m}$.

Clay: Fine, less micaceous (2.5YR6/6 light red).

Surface: Dark red glaze (10R5/6 red).

Restored. Rim zone: Rosettes with pointed petals. Main zone: Acanthus leaves, rosettes and bell flowers. In one circle the monogram $($ A. Base medallion: 8-petaled rosette surrounded by acanthus leaves.

Cf.: Hellström 1965, pl. 9 no 100; Siebert 1978, pl. 15, DI 39; Courby 1922, figs. 74-j; 76-3; 81-5; 86-4; Laumonier 1977, pl. 1 nos. 1260. 1971; Waagé 1941, fig. 11 no. 19; Rogl 2001, 
135-152; Rotroff - Oliver 2003, 113. 148 nos. 456.628 pls. 78. 109.

Date: $125-100 \mathrm{BC}$.

Cat. 23

Moldmade relief bowl

pls. 9. 14

Date and place of find: 05. 06. 2000, dromos.

H: $0.0765 \mathrm{~m}$; Dm at rim: $0.132 \mathrm{~m}$.

Clay: Fine (5YR7/6 reddish yellow).

Surface: Redbrown, dipped glaze (5YR4/1 dark gray).

Restored. Rim zone dogs chasing panthers. Main zone: Floral ornaments. Base medallion: 8-petaled rosette.

Cf.: Siebert 1978, pl. 12, DI 1. 2. 15; pl. 35, K 158; Courby 1922, fig. 79 no. 39; Laumonier 1977, pl. 78 nos. 2062. 3418. 8568; pl. 123 no. 882; Edwards 1975, 73 no. 843 pl. 36 (146 BC); Rotroff - Oliver 2003, 116-117 pl. 68 nos. 93. 94; pls. 73. 81. 85; cf. for buds nos. 369. 370. 440. 468; cf. for panthers nos. 404. 405. 491. 492. 571.

Date: $125-100$ BC.

\section{Cat. 24}

pls. 9.14

Moldmade relief bowl

Date and place of find: 05. 06. 2000, dromos.

H: $0.077 \mathrm{~m}$; Dm at rim: $0.114 \mathrm{~m}$.

Clay: 2.5YR6/6 light red.

Surface: Redbrown glaze (5YR3/1 very dark gray).

Restored. Rim zone: Bead and reel between ridges. Main zone: Lotus, acanthus leaves and loutrophoroi. Base medallion: 8-petaled rosette in double circles.

Cf.: Siebert 1978, pl. 15, DI 39; Courby 1922, fig. 81 no. 5; Laumonier 1977, pl. 15 no. 4987; pl. 36 no. 939; J. K. Brock, Excavations in Siphnos, BSA 44, 1949, pl. 21 no. 16; Gürler 1994, fig. 27 pl. 17 (2nd c. BC); Rotroff - Oliver 2003, nos. 378. $433^{56}-435$. 442. 454. 455. For loutrophoroi s. Bouzek - Jansova 1974, 51 MB 5 pl. 2, 3; 54 MB 21. MB 22, fig. 1 pl. 4; Conze 1913, 274 nos. 9. 15; Ziegenaus - de Luca 1968, 144 no. 295 pl. 51; 153 no. 352 pl. 55; Kögler 2000, 190 pls. 95 c. 96 b. 97 b; Christensen - Johansen 1971, 28-31 no. 119 figs. 13. 14.

Date: $125-100$ BC.

\section{Cat. 25}

Moldmade relief bowl

pls. 10. 15

Date and place of find: 05. 06. 2000, dromos.

H: $0.0745 \mathrm{~m}$; Dm at rim: $0.104 \mathrm{~m}$.

Clay: 2.5YR6/6 light red.

Surface: Around rim light red, on body dark red glaze (10R5/8 red).

Complete. Rim zone: Club motif between ridges. Main zone: Rounded ribless petals and acanthus leaves alternate with rosettes. At one point, in a circle the monogram $\mathbb{N}$. Base medallion: Pointed 8-petaled rosette.

Cf.: Courby 1922, fig. 76 no. 3; fig. 80 no. 3; Laumonier 1977, pl. 57 no. 5533-5542; pl. 60 no. 3253; Hellström 1965, pl. 11 nos. 142. 145; Rogl 2001, 142; Rotroff - Oliver 2003, 94 nos. 410. 450. 530.

Date: $125-100$ BC.
Cat. 26

pls. 10.15

Moldmade relief bowl

Date and place of find: 05. 06. 2000, dromos.

H: $0.0645 \mathrm{~m}$; Dm at rim: $0.099 \mathrm{~m}$.

Clay: 5YR4/1 dark gray.

Surface: Around rim light, other parts dark red glaze (10R5/8 red).

Complete. Main zone: Leaves. Base medallion: Dots around cross surrounded by grooves.

Date: $125-100$ BC.

Cat. 27

pls. 10. 16

Moldmade relief bowl

Date and place of find: 05. 06. 2000, dromos.

H: $0.0745 \mathrm{~m}$; Dm at rim: $0.127 \mathrm{~m}$.

Clay: 7.5 YR7/4 pink.

Surface: Brownblack glaze (5YR3/1 very dark gray, 5YR6/8 reddish yellow).

Restored. Rim zones: Dots between ridges; bead and reel. Main zone: Dolphins alternate with small lotus leaves. Base medallion: Circles with dots, surrounded by two concentric circles with palmettes in triangular fences.

Cf.: Courby 1922, fig. 76 no. 1; fig. 80 no. 8; Laumonier 1977, pl. 1 nos. 1260. 1981; pl. 11 nos. 4393. 4394; Hellström 1965, pl. 10 nos. 123. 126 (150-50 BC); Rotroff - Oliver 2003, nos. 446. 484.

Date: $125-100$ BC.

Cat. 29

pls. 10.16

Unguentarium

Date and place of find: 05. 06. 2000, dromos.

H: $0.165 \mathrm{~m}$; Dm at rim: $0.03 \mathrm{~m}$; Dm at base: $0.026 \mathrm{~m}$.

Clay: Fine (2.5YR4/2 weak red).

Surface: Unglazed (2.5YRN4/ dark gray).

Complete. Outturned thick rim, long neck, less profiled shoulder, long foot, flat base.

Cf.: Knigge 1976, pl. 69 no. 390 (2nd c. BC); Gürler 1994, fig. 39 pl. 29 no. 137; Kotitsa 1998, pl. 65 no. 114 (2nd half of 2nd c. BC); Anderson 1954, fig. 18 no. 327, 29-31; Rotroff - Oliver 2003, 69 no. 258 (2nd c. - 50 BC); Anderson Stojanovic 1992, pl. 67 no. 567.

Date: $125-100$ BC.

\section{Cat. 56}

Moldmade relief bowl

Date and place of find: 06. 06. 2000, dromos.

H: $0.0705 \mathrm{~m}$; Dm at rim: $0.111 \mathrm{~m}$.

Clay: Fine (2.5YR5/4 reddish brown).

Surface: Black glaze (5YR3/1 very dark gray); plain rim.

Restored. Rim zone: Inverted lotus buds between ridges. Main zone: Alternating palm fronds and buds separated by 9 -petaled rosettes. In the field inscription $[\ldots] \Delta \omega \mathrm{N}$. Base medallion: 8-petaled rosette.

Cf.: Courby 1922, fig. 81 no. 5; Laumonier 1977, pl. 20 no. 1746; Waagé 1941, fig. 13 no. 19; s. Rogl 2005, passim, for other samples and recent discussions on the name; Rotroff - Oliver 2003, 94. 203 pl. 134 B.

Date: 125-100 BC.

\footnotetext{
${ }^{56}$ For floral bowls s. Rotroff - Oliver 2003, 108 (150-31 BC); Hanfmann 1959, 30 note 60 (1st c. BC).
} 


\section{Cat. 57}

Moldmade relief bowl

Date and place of find: 06. 06. 2000, dromos.

H: $0.0735 \mathrm{~m}$; Dm at rim: $0.131 \mathrm{~m}$.

Clay: 5YR6/4 light reddish brown.

Surface: Partly preserved black glaze $(2.5 \mathrm{YRN} 3 /$ very dark gray).

pls. 10.17
Restored. Rim zone: Multi-petaled rosette between ridges. Main zone: Alternating swirling palm frond, Isis crown. Base medallion: In one circle 17-petaled rosette.

Cf.: Courby 1922, fig. 76 no. 3; cf. 389, no. 5; Laumonier 1977, pl. 30 no. 597 (medallion); pl. 21 no. 551; Hellström 1965, pl. 9.11 nos. 113. 154. 155 (mid 2nd c. BC); Rotroff - Oliver 2003, nos. 370 (Isis crown); 399 (swirling rosettes). Date: $125-100$ BC.

\section{Group C}

\section{Cat. 30}

pls. 18. 21

\section{Unguentarium}

Date and place of find: 06. 06. 2000, dromos.

H: $0.135 \mathrm{~m}$; Dm at rim: $0.027 \mathrm{~m}$; Dm at base: $0.025 \mathrm{~m}$.

Clay: Fine, less micaceous (5YR5/4 reddish brown).

Surface: Diagonal groups of five white (5YR8/4 pink) strips made over brown slip (5YR4/2 dark reddish gray).

Complete. Rounded thick rim, downwards narrowing neck, low profiled shoulder, short foot, ovoid body, circular base. Cf.: Knigge 1976, pl. 69 no. 390 (2nd c. BC); Rotroff - Oliver 2003, no. 258 (2nd c. -1 st half of 1st c. BC [?]); Anderson Stojanovic 1992, pl. 67 no. 567.

Date: $140-100$ BC.

Cat. 31

pls. 18. 21

Unguentarium

Date and place of find: 06. 06. 2000, dromos.

H: $0.145 \mathrm{~m}$; Dm at rim: $0.026 \mathrm{~m}$; Dm at base: $0.026 \mathrm{~m}$.

Clay: Badly fired (5YR5/6 yellowish red).

Surface: Less preserved brown glaze (5YR5/4 reddish brown).

Worn out base and rim. A couple of tiny grooves on lower body. Downturned thick rim, narrow neck, rounded shoulder, short foot, conical base.

Cf.: Knigge 1976, pl. 96 no. E 96, 2 (1st half of 3rd c. BC); Hayes - Neuru 1991, 106 O $\Delta 4420$ (late 2nd c. - early 1st c. BC); Metzger 1994, 72 pls. 34. 35 (150-100 BC).

Date: $140-100$ BC.

\section{Cat. 32}

pls. 18. 21

Unguentarium

Date and place of find: 06. 06. 2000, dromos.

H: $0.176 \mathrm{~m}$; Dm at rim: $0.029 \mathrm{~m}$; Dm at base: $0.025 \mathrm{~m}$.

Clay: Fine, less micaceous (5YR6/4 light reddish brown).

Surface: White stripe groups on plain surface (5YR8/2 pinkish white).

Complete. Downturned rim. Long neck, slightly profiled shoulder, long foot, conical base.

Cf.: Knigge 1976, pl. 69 no. 388 (HW 2) (2nd c. BC); Kotitsa 1998 , pl. 65 no. 114 (150-100 BC); Jones 1950, fig. 135 no. 235 (late 3rd c. BC); Rotroff - Oliver 2003, no. 262 (2nd c. - 1st half of 1st c. [?]); Anderson Stojanovic 1992, pl. 67 no. 568

Date: $140-100$ BC.

Cat. 33

pls. 18. 21

Unguentarium

Date and place of find: 06. 06. 2000, dromos.

H: $0.13 \mathrm{~m}$; Dm at rim: $0.026 \mathrm{~m}$; Dm at base: $0.024 \mathrm{~m}$.

Clay: Fine (2.5YR6/6 light red).
Surface: On body: White diagonal band groups on dark brown glaze (2.5YR3/2 dusky red).

Complete. Outturned rim, long neck, round shoulder, plump belly with a couple of grooves. Short foot, concave base. Cf.: s. also Cat. 3; Knigge 1976, pl. 96 no. E 93, 2 (1st half 3rd c.); Jones 1950, fig. 135 no. 239; Greenewalt 1979, fig. 16 (150-100 BC); Rotroff - Oliver 2003, T 77.1 (3rd/2nd c. $\mathrm{BC})$.

Date: $140-100$ BC.

Cat. 34

pls. 18. 21

Unguentarium

Date and place of find: 06. 06. 2000, dromos.

H: $0.175 \mathrm{~m}$; Dm at rim: $0.031 \mathrm{~m}$; Dm at base: $0.031 \mathrm{~m}$.

Clay: Less lime inclusions (2.5YR5/6 red).

Surface: On body two broad red bands (2.5YR5/6 red) on bad preserved cream white slip (5YR7/6 reddish yellow).

Complete. Outturned rim, long neck, plump body, short foot, broad projecting circular base.

Cf.: Knigge 1976, pl. 97 no. E 105 (2nd c. BC); Jones 1950, fig. 135 no. 234 (early 2nd c. BC); Barker - Bonanno - Riley 1977, fig. 113 no. D 684; Gürler 1994, fig. 37 pl. 27 no. 130 (250-200 BC); Günay 1989, fig. 8 b, Cat. 33 (125-100 BC); Rotroff - Oliver 2003, 70 no. 265 (late 2 nd - early 1st c. $\mathrm{BC})$

Date: $140-100$ BC.

Cat. 35

pls. 18. 21

Unguentarium

Date and place of find: 06. 06. 2000, dromos.

H: $0.126 \mathrm{~m}$; Dm at rim: $0.027 \mathrm{~m}$; Dm at base: $0.026 \mathrm{~m}$. Clay: Less sand inclusions (2.5YR6/6 light red).

Surface: Parallel red bands (2.5YR5/6 red) on cream glaze (7.5YR7/4 pink).

One piece of base is missing. Downturned rim, long neck, profiled shoulder, short foot narrows to flaring base.

Cf.: Knigge 1976, pl. 96 no. E 94, 1 (300-250 BC); Jones 1950, fig. 135 no. 234 (early 2nd c. BC).

Date: $140-100$ BC.

Cat. 36

pls. 18. 21

Unguentarium

Date and place of find: 06. 06. 2000, dromos.

H: $0.115 \mathrm{~m}$; Dm at rim: $0.022 \mathrm{~m}$; Dm at base: $0.02 \mathrm{~m}$. Clay: Tiny, less micaceous (10YR4/1 dark gray).

Surface: Less preserved stripe groups on gray-brown (10YR4/2 dark grayish brown) plain surface.

Complete. Outturned rim, narrow neck, distinctive shoulder profile, slender short foot, downward narrowing body. 
Cf.: Vessberg - Westholm 1956, fig. 24 no. 29; Knigge 1976, pl. 69 no. 388 (HW 2); Kotitsa 1998, pl. 65 no. 114; Gürler 1994, fig. 39 pl. 29 no. 137; Rotroff - Oliver 2003, T 77.1 (2nd c. -1 st half of 1st c. [?]) BC).

Date: $140-100$ BC.

\section{Cat. 37}

pls. 18. 21

\section{Unguentarium}

Date and place of find: 06. 06. 2000, dromos.

H: $0.098 \mathrm{~m}$; Dm at rim: $0.022 \mathrm{~m}$; Dm at base: $0.02 \mathrm{~m}$.

Clay: Fine (2.5YR6/6 light red).

Surface: On shoulder partly preserved black-brown glaze (2.5YR3/2 dusky red).

Complete. Slightly overhanging rim, short slender neck, round shoulder, ovoid body narrows through thick, projecting foot.

Cf.: Knigge 1976, pl. 68 no. 369 (HW 122), 1-4 (1st quarter of 3rd c. BC); Edwards 1975, pl. 20 no. 584 (325 BC); Jones 1950, fig. 135 no. 248 (end of 4th c. BC); Rotroff - Oliver 2003, 69 pl. 43 no. 254 (3rd c. BC [?]).

Date: End of 4th - beginning of 3rd c. BC (?).

\section{Cat. 38}

pls. 18. 21

Unguentarium

Date and place of find: 06. 06. 2000, dromos.

H: $0.118 \mathrm{~m}$; Dm at rim: $0.026 \mathrm{~m}$; Dm at base: $0.02 \mathrm{~m}$.

Clay: Less micaceous (5YR5/6 yellowish red).

Surface: Partly preserved cream glaze (7.5YR8/4 pink) on shoulder and rim with redbrown bands (5YR6/6 reddish yellow).

Complete. Slightly overhanging rim, long neck, plump body, short foot, conical foot.

Cf.: Knigge 1976, pl. 97 no. E 98, 1 (300-250 BC); Vessberg - Westholm 1956, fig. 24 no. 25; Greenewalt 1979, fig. 16 (150-100 BC); Rotroff - Oliver 2003, 71 pl. 45 no. 265 (late 2nd - early 1st c. BC); Gassner 1997, no. H 96, pl. 76 (hellenistic - 1st c. AD).

Date: $140-100$ BC.

\section{Cat. 39}

pls. 19. 22

Ephesos lamp

Date and place of find: 06. 06. 2000, dromos.

Pres. L: 0.096 m; W: 0.057 m; H: 0.0335 m; Dm discus gap: $0.015 \mathrm{~m}$.

Clay: 5YR7/1 light gray.

Surface: Less preserved black glaze (5YR3/1 very dark gray).

Complete. Non-handle double conical body. Long nozzle with burn traces on tip. Flat, circular base. Lotus leaves and floral ornaments on shoulder.

Cf.: Günay Tuluk 1996, fig. 11 a, no. 67 (125-0 BC).

Date: $125-100$ BC.

\section{Cat. 40}

pls. 19. 22

Heart shape lamp

Date and place of find: 06. 06. 2000, dromos.

Pres. L: $0.096 \mathrm{~m}$; W: $0.067 \mathrm{~m}$; H: $0.029 \mathrm{~m}$.

Dm discus gap: $0.012 \mathrm{~m}$.

Clay: 5YR7/6 reddish yellow.

Surface: Red glaze (2.5YR5/6 red).

Complete. Double conical body. On either side project- ing holding lugs. Small discus. Concentric plastic bands surrounding a round base. Egg and dart on shoulder.

Cf.: Günay Tuluk 1996, pl. 9 b, no. 52 (last quarter of 2nd c. - 1st c. BC); Hellström 1965, pl. 24 no. 44 (1st c. BC); Chrzanovski - Zhuravlev 1998, 49 no. 14 (end of 2nd c. - 75 BC); Barr 1996, 184-186 Cat. 85.

Date: $125-100$ BC.

\section{Cat. 41}

pls. 19. 22

Heart shape lamp

Date and place of find: 06. 06. 2000, dromos.

Pres. L: 0.103 m; W: 0.076 m; H: 0.032 m; Dm discus gap: $0.016 \mathrm{~m}$.

Clay: Micaceous, sandy.

Surface: Less preserved shiny gray glaze (7.5YRN6/ gray). Complete. Holding knobs on both side of globular body. Small discus. Rounded tip long nozzle. Concentric plastic bands around circular base with a dot in the centre.

Cf.: s. Cat. 45.

Date: $140-100$ BC.

Cat. 42

pls. 19. 22

Ephesos lamp

Date and place of find: 06. 06. 2000, dromos.

Pres. L: 0.107 m; W: 0.055 m; H: 0.032 m; Dm discus gap: $0.012 \mathrm{~m}$.

Clay: Less micaceous (5YR5/4 reddish brown).

Surface: Black glaze (2.5YRN3/ very dark gray).

Complete, handle missing. Double conical body. On shoulder meander separated by rosettes. Long, arrow-tip nozzle with three line groups on top. Stylized palmette in front of discus gap. Two concentric plastic bands around circular base with dot in the center.

Cf.: Günay Tuluk 1996, pl. 67 a, no. 377 (125/100 BC-1st c. BC); Kassab Tezgör - Sezer 1995, no. 356 (1st c. BC); Menzel 1954, no. 57.

Date: $125-100$ BC.

Cat. 43

pls. 19. 22

Ephesos lamp

Date and place of find: 06. 06. 2000, dromos.

Pres. L: 0.12 m; W: 0.064 m; H: 0.037 m; Dm discus gap: $0.015 \mathrm{~m}$.

Clay: 5YR4/1 dark gray.

Surface: Less preserved metallic glaze (7.5YRN4/ dark gray).

Complete. Double conical body. Plastic band around small discus gap. Long nozzle with round, flat-top nozzle. Concentric double plastic bands around base. Waves on shoulder and palmette on nozzle.

Cf.: Günay Tuluk 1996, pl. 13 a, no. 73 (125/100 BC-1st c. BC); Zapheiropoulos - Chatzedakis 1994, pl. 187ß (125-75 $\mathrm{BC})$.

Date: $125-100$ BC.

Cat. 44

pls. 19. 22

Heart shape lamp

Date and place of find: 06. 06. 2000, dromos.

Pres. L: 0.096 m; W: 0.061 m; H: 0.035 m; Dm discus gap: $0.015 \mathrm{~m}$.

Clay: Micaceous (5YR4/1 dark gray). 
Surface: Less preserved shiny black-gray glaze (7.5YRN4/ dark gray).

Secondary fired. Tip of nozzle broken. Conical body with protrusion on one side. Plastic band around discus gap. Long nose with rounded tip. Two plastic bands on base. Floral ornaments on shoulder.

Cf.: Günay Tuluk 1996, pl. 5 b, no. 32.

\section{Cat. 45}

pls. 19. 23

Heart shape lamp

Date and place of find: 06. 06. 2000, dromos.

Pres. L: 0.113 m; W: 0.083 m; H: 0.031 m; Dm discus gap: $0.022 \mathrm{~m}$.

Clay: Small sand particle, mica (2.5YR5/6 red).

Surface: Unglazed (2.5YR5/6 red).

Complete. On both sides heart shaped holding knobs. Nonhandle globular body. Two plastic bands around wide discus gap. Long, rounded nozzle tip. Ring base.

Cf.: s. Cat. 41.

Date: $140-100$ BC.

Cat. 46

pls. 19. 23

Ephesos lamp

Date and place of find: 06. 06. 2000, dromos.

Pres. L: $11.2 \mathrm{~cm}$; W: $6.5 \mathrm{~cm}$; $: 4.5 \mathrm{~cm}$; Dm discus gap: $1.2 \mathrm{~cm}$.

Clay: Fine (7.5YRN5/ gray).

Surface: Metallic black gray glaze (7.5YRN4/ dark gray).

Complete, handle missing. Double conical body, small discus surrounded by plastic bands. Arrow shaped nozzle with flattop. Concentric plastic bands with central dot at round base. On shoulder flower, lotus petals and wine branches. Stylized heart shaped leaf on nozzle.

Cf.: Günay Tuluk 1996, pl. 67 c, no. 378 (last quarter of 2nd c. - 1st c. BC); Kassab Tezgör - Sezer 1995, no. 339 (last quarter of 2nd c. - 1st c. BC); Gürler 2003, 13 pl. 12 no. A 47 (end of 3rd c. BC).

Date: $125-100$ BC.

Cat. 47

pls. 19. 23

Ephesos lamp

Date and place of find: 06. 06. 2000, dromos.

Pres. L: 0.131 m; W: 0.066 m; H: 0.035 m; Dm discus gap: $0.012 \mathrm{~m}$.

Clay: (7.5YR7/2 pinkish gray).

Surface: Shiny, black-gray glaze (7.5YRN5/ gray).

Complete. Double conical body. Shallow discus. Long roundtip nozzle with flat top. Plastic ribbon attachment on double grooved handle. Flat base. Egg and dart on shoulder. Ropes of flowers girdle on nozzle.

Cf.: s. also Cat. 14; Kassab Tezgör - Sezer 1995, no. 339 (last quarter of 2 nd c. -1 st c. BC); Hayes 1980, no. 56 (1st c. BC); Howland 1958, pl. 49 nos. 653. 659 (end of 2nd c. BC). Date: $125-100$ BC.

\section{Cat. 48}

pls. 20.23

Heart shape lamp

Date and place of find: 06. 06. 2000, dromos.

Pres. L: 0.118 m; W: 0.07 m; H: 0.037 m; Dm discus gap: $0.012 \mathrm{~m}$.

Clay: 10YR4/2 dark grayish brown.
Surface: Metallic gray glaze (7.5YRN3/ very dark gray).

Double conical body. On both sides heart shaped holding knobs. Small discus. Long nozzle with rounded, flat-top tip. Ring handle. Slightly concave base.

Cf.: Probably a variant of Cat. 41. 45.

Date: $140-100$ BC.

\section{Cat. 49}

pls. 20. 23

Ephesos lamp

Date and place of find: 06. 06. 2000, dromos.

Pres. L: $0.111 \mathrm{~m}$; W: 0.066 m; H: 0.035 m; Dm discus gap: $0.012 \mathrm{~m}$.

Clay: Fine (7.5YRN7/ light gray).

Surface: Shiny, dark gray glaze (7.5YRN4/ dark gray).

Double conical body. Plastic band around small discus gap. Arrow shaped nozzle with slightly fragmented flat top. Two concentric plastic rings around base with central dot. Palmette, lotus petals at shoulder. On channel stylized leaf in heart shape.

Cf.: Günay Tuluk 1996, fig. 11 a, no. 67 pl. 67 c (last quarter of 2nd c. - 1st c. BC); G. Günay Tuluk, Ionia Bölgesi'ndeki Hellenistik Döneme ait Kandiller, in: Abadie-Reynal 2003, 24 pl. 24, A 47; Kassab Tezgör - Sezer 1995, nos. 339. 342 (last quarter of 2nd c. - 1st c. BC); Gürler 2003b, 123 Cat. 2 (275-250 BC); Scheibler 1976, 116; Bruneau 1965, pl. 13 nos. 2410. 2427. 2449. 2478; Wiegand - Schrader 1904, 452 no. 180; Ziegenaus - De Luca 1968, pl. 55; Zapheiropoulos - Chatzedakis 1994, 241-242 pl. 187ß, 14929 (125-100 BC). Date: $125-100 \mathrm{BC}$.

Cat. 50

pls. 20.23

Heart shape lamp

Date and place of find: 06. 06. 2000, dromos.

L: $0.117 \mathrm{~m}$; W: $0.061 \mathrm{~m}$; H: $0.04 \mathrm{~m}$; Dm discus gap: $0.015 \mathrm{~m}$. Clay: Fine, less micaceous (2.5YR6/6 light red).

Surface: plain (2.5YR5/6 red).

Complete. Double conical body. Heart shaped holding knobs on each sides. Plastic bands around discus. Long roundedtip nozzle. Ring handle. Concave base. Floral running spirals (ivy?) on shoulder and nozzle.

Cf.: Günay Tuluk 1996, pl. 5 f, no. 50 (2nd c. -1 st c. BC); Hellström 1965, pl. 23 no. 89; Kassab Tezgör - Sezer 1995, no. 306 (last quarter of 2 nd c. -1 st c. BC); Lang-Auinger 2003, 39, pl. 24, L 4.

Date: $125-100$ BC.

Cat. 62

pls. 20. 24

Ephesos lamp

Date and place of find: 06. 06. 2000, dromos.

Pres. L: 0.119 m; W: 0.066 m; H: 0.0355 m; Dm discus gap: $0.011 \mathrm{~m}$.

Clay: Very micaceous (2.5YRN5/ gray).

Surface: Black glaze (2.5YRN3/ very dark gray).

Complete, handle missing, round nozzle tip with flat top broken. Double conical body. Plastic band around discus bowl, three small holes. Flat base. Egg and dart on shoulder. Eros head on nozzle.

Cf.: Kassab Tezgör - Sezer 1995, no. 294 (last quarter of 2nd c. -1 st c. BC); Hayes 1980, no. 56 (1st c. BC); Günay Tuluk 1996, fig. 29 a, no. 171.

Date: $125-100 \mathrm{BC}$. 


\section{Cat. 72}

pls. 20. 24

\section{Unguentarium}

Date and place of find: 06. 06. 2000, dromos.

H: $0.189 \mathrm{~m}$; Dm at rim: $0.031 \mathrm{~m}$; Dm at base: -.

Clay: Fine (5YR5/4 reddish brown).

Surface: Plain, gray brown surface (7.5YR5/4 brown).

Foot, base missing. Outturned rim, long slender neck, distinctive shoulder profile, body narrows through down.

Cf.: Knigge 1976, pl. 69 no. 388 (HW 2) (200-150 BC); Anderson 1954, fig. 18 no. 328 (100-75 BC); Jones 1950, fig. 135 nos. 235. 245 (late 3rd c. BC); Gürler 1994, fig. 40 pl. 30, no. 144 (150-100 BC); Rotroff - Oliver 2003, 70 pl. 44 Cat. 262 (2nd c. -1 st half of 1st c. BC); Zapheiropoulos - Chatzedakis 1994, pl. 198ß, 14999 (108-88 BC).

Date: $140-100$ BC.

\section{Cat. 73}

pls. 20. 24

Unguentarium

Date and place of find: 06. 06. 2000, dromos.

H: $0.121 \mathrm{~m}$; Dm at rim: $0.024 \mathrm{~m}$; Dm at base: -

Clay: Fine (7.5YR6/6 reddish yellow).

Surface: Less preserved black glaze $(2.5$ YR5/4 reddish brown).

Secondary fired, rim and base worn out due to the fire. Downturned thick rim; slender neck; rounded shoulder, plump belly with one groove, short foot, conical base.

Cf.: Günay 1989, fig. 3 b, no. 10 (beginning of 3rd c. BC); Vessberg - Westholm 1956, fig. 24 no. 25.

Date: 2nd c. BC (?).

\section{Cat. 74}

pls. 20.24

\section{Unguentarium}

Date and place of find: 06. 06. 2000, dromos

$\mathrm{H}: 0.134 \mathrm{~m}$; Dm at rim: $0.025 \mathrm{~m}$.

Clay: Less micaceous, sandy (5YR6/6 reddish yellow).

Surface: Pale brown (7.5YR7/4 pink) band groups on plain red surface.

Worn out, thick downturned rim. Long neck; round shoulder, double groove on lower body.
Cf.: Anderson 1954, fig. 18 no. 328; Kotitsa 1998, pl. 65 no. 114 (150-100 BC); Jones 1950, fig. 135 no. 235 (2nd c. BC); Rotroff - Oliver 2003, no. 263 (2nd c. - 1st half of 1st c. BC); Hayes - Neuru 1991, 145 no. 33 pl. 16, 5 O 3137 (100-60 $\mathrm{BC})$.

Date: $140-80 \mathrm{BC}$.

\section{Cat. 75}

Unguentarium

Date and place of find: 06. 06. 2000, dromos

H: $0.1375 \mathrm{~m}$; Dm at rim: $0.029 \mathrm{~m}$.

Clay: Badly fired, coarse clay (7.5YR4/2 dark brown).

Surface: Pale brown (7.5YR4/4 pink) transverse band groups on plain surface.

Foot, base missing. Outturned rim, long slender neck, distinctive shoulder profile, body narrows through down.

Cf.: Anderson 1954, fig. 18 no. 328 (1st quarter of 1st c. BC). Date: $125-100$ BC.

Cat. 100

pl. 20

Cylindrical bead

Date and place of find: 06. 06. 2000, from bothros which consists of ashes and bones in northeastern half of the dromos.

Pres. L: 0.03 m; Dm 0.009 m.

Blue glass with yellow waves.

Date: $140-80$ BC.

Cat. 101

Medical tool

Date and place of find: 06. 06. 2000, from bothros which consists of ashes and bones in northeastern half of the dromos.

Pres. L: 0.14 m; Dm: 0.002 m.

Bronze, in fragments. Body in circular section. Tip of handle is swollen in drop shape, while the other end having a spoon.

Cf.: Waldbaum 1983, 105 pl. 41 nos. 20. 21.

Date: -

\section{Group D}

\section{Cat. 28}

Wheelmade lamp

Date and place of find: 05. 06. 2000, dromos.

Pres. L: 0.089 m; W: 0.056 m; H: 0.035 m; Dm discus gap: $0.016 \mathrm{~m}$.

Clay: Fine, less micaceous (2.5YR6/6 light red).

Surface: Red slip (2.5YR5/6 red).

Complete. Globular body, one groove around discus. Wide discus gap. On one side a holding knob. Arrow type nozzle with fired tip. At base concentric plastic bands.

Cf.: Günay Tuluk 1996, pl. 3 b, no. 22 (300-250 BC); Oziol 1977, pl. 57 no. 53 (end of 2nd c. BC); Jones 1950, fig. 93 no. 20 (250-100 BC).

Date: $140-100$ BC.

\section{Cat. 52}

pl. 25

Conical bowl

Date and place of find: 06. 06. 2000, dromos.
H: $0.074 \mathrm{~m}$; Dm at rim: $0.17 \mathrm{~m}$.

Clay: Sandy (2.5YR6/6 light red).

Surface: Inside red, outside around rim dark brown glaze (2.5YR3/4 dark reddish brown).

In fragments. One groove at tondo, three inside rim. Tiny parallel grooves on exterior walls. Similar to Cat. 16 except flower at tondo.

Cf.: s. Cat. 16.

Date: $150-100$ BC.

Cat. 53

Conical bowl

Date and place of find: 06. 06. 2000, dromos.

H: $0.063 \mathrm{~m}$; Dm at rim: $0.168 \mathrm{~m}$.

Clay: Fine (10YR6/1 light gray).

Restored. Less preserved glaze. Three grooves inside rim, 6-petaled white flowers at tondo.

Cf.: s. Cat. 2. 58.

Date: $150-100$ BC. 


\section{Cat. 54}

pls. 25.29

Conical bowl

Date and place of find: 06. 06. 2000, dromos.

H: $0.0665 \mathrm{~m}$; Dm at rim: $0.177 \mathrm{~m}$.

Clay: Micaceous (7.5YRN6/ gray).

Surface: Dark brown at rim, light brown (7.5YR4/2 dark brown) glaze inside. White painted 8-petaled rosette at tondo and ivy around rim (7.5YR8/2 pinkish white).

Restored. Three grooves inside rim. One groove around convex base. West Slope Style.

Cf.: s. Cat. 1. 2. 15. 16. 52. 53; Edwards 1975, no. 532-541 pls. 40. 55; Anderson 1954, nos. 234. 236 pl. 11.

Date: $150-100$ BC.

\section{Cat. 55}

pls. 25.29

Moldmade relief bowl

Date and place of find: 06. 06. 2000, dromos.

H: $0.765 \mathrm{~m}$; Dm at rim: $0.127 \mathrm{~m}$.

Clay: Fine (2.5YR6/6 light red).

Surface: Brown glaze (2.5YR4/2 weak red).

Restored. Rim zones: Bead and reel between ridges; egg and dart. Main zone: Row of loutrophoroi. Base medallion: Rosette surrounded by double concentric circles.

Cf.: s. Cat. 24; Courby 1922, fig. 76 nos. 2. 5; Gürler 1994, fig.

27 no. 87 (2nd c. BC); Hellström 1965, pl. 10 no. 126; Rotroff

- Oliver 2003, 108 (150-31 BC), cf. nos. 378. 433-435. 442.

454. 455; Hanfmann 1959, 30 note 60 (1st c. BC).

Date: $150-100$ BC.

\section{Cat. 58}

pl. 25

Conical bowl

Date and place of find: 06. 06. 2000, dromos.

Dm at rim: $0.164 \mathrm{~m}$.

Clay: Fine (2.5YR6/6 light red).

Surface: Red glaze at rim (10R5/8 red) brown glaze inside (5YR4/2 dark reddish gray). White leaves at tondo (10YR8/3 very pale brown).

In several fragments. Inside double grooves at rim, one in middle, one around tondo. Groove around convex base. West Slope Style.

Cf.: s. Cat. 2. 53.

Date: $150-100$ BC.

\section{Cat. 59}

pl. 26

Conical bowl

Date and place of find: 06. 06. 2000, Dromos.

Dm at rim: $0.1802 \mathrm{~m}$.

Clay: Fine (5YR5/3 reddish brown).

Surface: Inside and outside redbrown glaze (5YR4/2 dark reddish gray).

In several fragments. Double grooves inside rim while one around convex base outside.

Cf.: s. Cat. 2. 53; Edwards 1975, no. 532-541 pls. 40. 55; Crowfoot - Crowfoot - Kenyon 1957, fig. 53 no. 1, Q 4666; Anderson 1954, pl. 11 nos. (b)244-247.

Date: $150-100$ BC.

\section{Cat. 60}

pls. 26. 30

Moldmade bowl

Date and place of find: 06. 06. 2000, dromos

$\mathrm{H}: 0.054 \mathrm{~m}$; Dm at rim: $0.134 \mathrm{~m}$.
Clay: 2.5YR6/6 light red.

Surface: Dark brown glaze around rim (10YR3/1 dark gray). Red glazed body (2.5YR5/6 red).

Rim and upper body fragment. Ionic cymation at the rim, small fern leaves on upper part of the body.

Cf.: Courby 1922, fig. 76 no. 2; Jones 1950, fig. 139 no. 316; Siebert 1978, pl. 32 nos. K 1. K 15.

Date: 2nd c. BC.

Cat. 61

pls. 26. 30

Moldmade relief bowl

Date and place of find: 06. 06. 2000, dromos.

H: $0.0725 \mathrm{~m}$; Dm at rim: $0.105 \mathrm{~m}$.

Clay: 5YR5/4 reddish brown.

Surface: Black glaze around rim (5YR3/1 very dark gray). Inside and lower body outside unglazed (5YR5/3 reddish brown).

Restored. Stylized star at medallion where out growing leaves cover lower half of the body. Leaves separated by stylized palm fronds.

Cf.: s. Cat. 26.

Date: $150-100$ BC.

Cat. 63

pls. 26. 31

Echinus bowl

Date and place of find: 06. 06. 2000, dromos.

Dm at rim: $0.09 \mathrm{~m}$; H: $0.036 \mathrm{~m}$.

Clay: Fine (2.5YR6/6 light red).

Surface: Dipped red glaze (2.5YR5/6 red).

Rim and body fragment. On body a distinctive groove, below tiny parallel grooves.

Cf.: Schäfer 1968, pl. 4, C15 (300 BC); Lapp 1961, 201, A (200-150 BC); Gürler 1994, pl. 76 fig. 6 no. 19 (2nd c. BC); Rotroff 1997, 341 no. 1005 (250-200 BC); Berlin 1999, pl. 21 nos. 113. 114 (end of 3rd c. BC); Rotroff - Oliver 2003, $27 \mathrm{pl}$. 8 no. 40 (late Hellenistic - early 1st c. AD).

Date: $200-150$ BC.

Cat. 64

pls. 26. 31

Hemispherical bowl

Date and place of find: 06. 06. 2000, dromos.

H: $0.049 \mathrm{~m}$; Dm at rim: $0.141 \mathrm{~m}$.

Clay: Sandy (5YR6/6 reddish yellow).

Surface: On rim red-black glaze (5YR5/1 gray). Light red glaze on body (5YR7/4 pink).

Rim and body fragment. Outside rim double grooves. Parallel grooves on body and inside rim.

Cf:: -

Date: -

Cat. 65

Moldmade relief bowl

pls. 26. 31

Date and place of find: 06. 06. 2000, dromos.

H: $0.07 \mathrm{~m}$; R. at rim: $0.10 \mathrm{~m}$.

Clay: Fine (2.5YR6/6 light red).

Surface: Red glaze (2.5YR5/6 red).

Rim and body fragment. Rim zone: Dots between ridges. Main zone: Row of palmettes separated by dots. Base medallion: Unidentified.

Cf.: Courby 1922, fig. 76 no. 1; Rotroff - Oliver 2003, pl. 81 no. 470 .

Date: - 


\section{Cat. 66}

Moldmade relief bowl

Date and place of find: 06. 06. 2000, dromos.

H: $0.067 \mathrm{~m}$; Dm at rim: $0.10 \mathrm{~m}$.

Clay: Fine (2.5YR6/6 light red).

Surface: Red glaze (2.5YR5/6 red). On rim black glaze (10R3/1 dark reddish gray).

Restored. Straight rim with slightly everted lip. Rim zone: Between ridges row of circles with central dots. Main zone: Palm fronds separated by small pointed leaves.

Cf.: Courby 1922, fig. 80 no. 8; fig. 81 no. 5; Laumonier 1977, pl. 36 no. 939; Gürler 1994, fig. 16 pl. 7 no. 49 (250-200 BC); Jones 1950, fig. 139 no. 316; Rotroff - Oliver 2003, 138 pl. 101 no. 578 .

Date: -

\section{Cat. 67}

pls. 27. 31

Pitcher

Date and place of find: 06. 06. 2000, dromos

$\mathrm{H}: 0.085 \mathrm{~m}$; Dm at rim: $0.11 \mathrm{~m}$.

Clay: Tiny sandy (5YR6/4 light reddish brown).

Surface: Brown slipped (2.5YR4/4 reddish brown).

Rim and neck fragment. One handled. Outturned rim.

Cf.: Cat. 17.

Date: -

Cat. 68

pls. 27. 31

Pitcher

Date and place of find: 06. 06. 2000, dromos

$\mathrm{H}: 0.085 \mathrm{~m}$; Dm at rim: $0.106 \mathrm{~m}$.

Clay: 2.5YR6/6 light red.

Surface: Less preserved brown glaze (5YR5/4 reddish brown).

Rim and neck fragment. One handled. Outturned slim rim. Cf.: Cat. 17; Barker - Bonanno - Riley 1977, fig. 136 no. D 1116 (Hellenistic jug).

Date: -

Cat. 69

pls. 26. 32

Pitcher

Date and place of find: 06. 06. 2000, dromos.

H: $0.046 \mathrm{~m}$; Dm at rim: $0.124 \mathrm{~m}$.

Clay: Fine (2.5 YR 6/6 light red).

Surface: Plain.

Rim and neck fragment. Outturned rim.

Cf.: Crowfoot - Crowfoot - Kenyon 1957, fig. 58 no. 9 (3rd2nd c. BC); Barker - Bonanno - Riley 1977, fig. 136 no. D 1116.

Date: Hellenistic period.

\section{Cat. 70}

pls. 27. 32

\section{Conical bowl}

Date and place of find: 06. 06. 2000, dromos.

H: $0.05 \mathrm{~m}$; Dm at rim: $0.17 \mathrm{~m}$.

Clay: Tiny sandy, less micaceous (7.5YR6/4 light brown).

Surface: Plain (2.5YR6/6 light red).

Rim and body fragment. Outside, double groove below rim.

Cf.: Cat. 1. 2. 15. 16.

Date: 2nd c. BC.

Cat. 71

pls. 27. 32

Moldmade relief bowl

Date and place of find: 06. 06. 2000, dromos.

Pres. H: $0.039 \mathrm{~m}$; Dm at rim: $0.126 \mathrm{~m}$.

Clay: Fine (2.5YR5/6 red).

Surface: Red glaze (2.5YR4/6 red).

Rim and body fragment. Thick rim. Rim zone: Egg and dart between ridges. Main zone: Alternating palm fronds and lotus petals separated by small leaves. Base medallion: Rosette.

Cf.: Courby 1922 , fig. 76 no. 2 ; Waagé 1941 , fig. 9 no. 14; Hellström 1965, pl. 9 no. 98; Laumonier 1977, 891 pl. 20 no. A 62,891; Rotroff - Oliver 2003, nos. 452. 453.

Date: $150-100$ BC.

\section{Cat. 78}

pls. 27. 32

Pitcher

Date and place of find: 06. 06. 2000, dromos.

$\mathrm{H}: 0.078 \mathrm{~m}$; Dm at rim: $0.105 \mathrm{~m}$.

Clay: Fine (2.5YR5/6 red).

Surface: Dark brown glaze (5YR4/3 reddish brown).

Rim and neck fragment. Overhanging thick rim. Three grooves on neck.

Cf.: -

Date: Hellenistic period.

Cat. 79

pl. 32

Pitcher

Date and place of find: 06. 06. 2000, dromos.

H: $0.029 \mathrm{~m}$; Dm at rim: $0.123 \mathrm{~m}$.

Clay: Fine (7.5YR4/4 dark brown).

Surface: Red-black glaze (2.5YR5/4 reddish brown).

Rim and neck fragment. Outturned thick rim.

Cf.: Barker - Bonanno - Riley 1977, fig. 136 no. D 1116.

Date: Hellenistic period.

\section{Cat. 80}

pls. 27. 32

Pitcher

Date and place of find: 06. 06. 2000, dromos.

H: $0.075 \mathrm{~m}$; Dm at rim: $0.128 \mathrm{~m}$.

Clay: Fine (2.5YR5/6 red).

Surface: Plain (2.5YR6/4 light reddish brown).

Rim and neck fragment. Overhanging rounded rim.

Cf.: Barker - Bonanno - Riley 1977, fig. 136 no. D 1116; Rotroff - Oliver 2003, 64 pl. 36 (probably before 213 BC).

Date: Hellenistic period.

Cat. 81

Moldmade relief bowl

Date and place of find: 06. 06. 2000, dromos.

$\mathrm{H}: 0.051 \mathrm{~m}$; Dm at rim: $0.109 \mathrm{~m}$.

Clay: Micaceous (2.5YR5/8 red).

Surface: Red glaze (10R5/6 red).

Rim and body in fragments. Rim zone: Club motifs between ridges.

Cf.: Rotroff - Oliver 2003, nos. 450. 478. 530 (2nd/1st c. BC); Laumonier 1977, pl. 28 no. 8420.

Date: 2nd c. BC.

pls. 27. 32 


\section{Cat. 82 a}

Pitcher

Date and place of find: 06. 06. 2000, dromos.

$\mathrm{H}: 0.033 \mathrm{~m}$; Dm at rim: $0.116 \mathrm{~m}$.

Clay: Fine (2.5YR5/6 red).

Surface: Plain (2.5YR6/4 light reddish brown).

Rim and body fragment. Outturned rim.

Cf.: -

Date: Hellenistic period.

\section{Cat. 82 c}

Pitcher

Date and place of find: 06. 06. 2000, dromos.

H: $0.02 \mathrm{~m}$; Dm at rim: $0.148 \mathrm{~m}$.

Clay: Sandy (5YR6/6 reddish yellow).

Surface: Less preserved dark brown slip (5YR5/2 reddish gray).

Fragment. Outturned rim and flaring neck.

Cf.: Barker - Bonanno Riley 1977, fig. 135 no. 1100.

Date: Hellenistic period.

\section{Cat. 82 d}

pl. 32

Pitcher

Date and place of find: 06. 06. 2000, dromos.

$\mathrm{H}: 0.016 \mathrm{~m}$; Dm at rim: $0.111 \mathrm{~m}$.

Clay: Fine (2.5YR5/6 red).

Surface: Brown slip (5YR6/4 light reddish brown).

Rim and body fragment. Overhanging rim.

Cf.: s. Cat. 82 c.

Date: Hellenistic period.

\section{Cat. 83 a}

Pitcher

Date and place of find: 06. 06. 2000, dromos.

H: $0.043 \mathrm{~m}$; Dm at rim: $0.10 \mathrm{~m}$.

Clay: Sandy and micaceous (2.5YR5/6 red).

Surface: Less preserved redbrown slip (2.5YR5/4 reddish brown).

Rim and neck fragment. Outturned thick rim.

Cf.: -

Date: Hellenistic period.

\section{Cat. 83 b}

pl. 33

Pitcher

Date and place of find: 06. 06. 2000, dromos.

H: $0.053 \mathrm{~m}$; Dm at rim: $0.133 \mathrm{~m}$.

Clay: Very micaceous (2.5YR6/6 light red).

Surface: Partly preserved brown slip (5YR5/3 reddish brown).

Rim and neck fragment. Outturned thick rim.

Cf.: -

Date: Hellenistic period.

\section{Cat. 84 a}

Pitcher

Date and place of find: 06. 06. 2000, dromos.

H: $0.053 \mathrm{~m}$; Dm at rim: $0.103 \mathrm{~m}$.

Clay: Fine (5YR6/6 reddish yellow).

Surface: Redbrown glaze (5YR5/4 reddish brown).

Rim and neck fragment. Outturned rim.

Cf.: -

Date: Hellenistic period.

\section{Cat. 84 b}

pls. 27. 33

Pitcher

Date and place of find: 06. 06. 2000, dromos.

H: $0.051 \mathrm{~m}$; Dm at rim: $0.111 \mathrm{~m}$.

Clay: Fine (2.5YR5/6 red).

Surface: Redbrown slip (2.5YR5/4 reddish brown). Rim and neck fragment. Outturned sloping rim.

Cf.: Edwards 1975, 115 pl. 24 no. 636 (175-150 BC).

Date: Hellenistic period.

\section{Cat. 85}

pl. 33

Pitcher base

Date and place of find: 06. 06. 2000, dromos.

$\mathrm{H}: 0.04 \mathrm{~m}$; Dm at rim: $0.098 \mathrm{~m}$.

Clay: Golden mica particles (2.5YR5/6 red).

Surface: Plain (5YR7/4 pink).

Base and body fragment. Groove between flaring ring base and body.

Cf.: -

Date: Hellenistic period.

\section{Cat. 86}

pls. 28. 33

Ephesos lamp

Date and place of find: 06. 06. 2000, dromos.

Pres. L: 0.102 m; W: 0.065 m; H: 0.035 m; Dm discus gap: $0.017 \mathrm{~m}$.

Clay: Less micaceous (10YR6/3 pale brown).

Surface: Red-cream slip (5YR6/6 reddish yellow).

Fragments. Double conical body. Tiny groove around discus. Long nozzle with fired tip. Flat oval base. Overlapping small, pointed leaves on shoulder.

Cf.: Gürler 1994, fig. 17 pl. 8 (2nd c. BC); Hellström 1965, pl. 10 nos. 127.129.

Date: 200-100 BC.

\section{Cat. 87}

pls. 28. 33

Wheelmade lamp

Date and place of find: 06. 06. 2000, dromos.

Pres. L: 0.104 m; W: 0.075 m; H: 0.035 m.

Clay: Sandy, micaceous (2.5YR6/6 light red).

Surface: Plain.

Fragments. Circular body, open discus, inside curving rim, short nozzle with fired tip, concave base.

Cf.: Kassab Tezgör - Sezer 1995, nos. 114. 117 (end of 5th c. BC).

Date: 5th c. BC.

\section{Cat. 88}

pls. 28. 33

\section{Ephesos lamp}

Date and place of find: 06. 06. 2000, dromos.

Pres. L: $0.11 \mathrm{~m}$; W: 0.05 m; H: 0.045 m; Dm discus gap: $0.015 \mathrm{~m}$.

Clay: Fine (7.5YR5/2 brown).

Surface: Black-gray glaze (7.5YRN4/ dark gray).

Restored. Double conical body. Ring handle. Tiny band around small discus. Long nozzle with round tip. Slave mask on nozzle. Flat, oval base.

Cf.: Günay Tuluk 1996, pl. 13 no. 73 (mid 2nd c. - 1st c. $\mathrm{BC})$.

Date: $150-80 \mathrm{BC}$. 


\section{Cat. 96}

Iron nails

pl. 28

Date and place of find: 06. 06. 2000, found in and around bothros at northeastern half of the dromos, Group C, D.

Pres. L: $0.06-0.07 \mathrm{~m}$.

Iron nail fragments with flat heads.

Cf.: Waldbaum 1983, 68 pl. 21.

Date: -

Cat. 102

pl. 28

Terracotta ball

Date and place of find: 06. 06. 2000, found near bothros pit at northeastern half of the dromos.

Dm: $0.05 \mathrm{~m}$

Rough clay, surface black by firing.

Cf.: -

Date: -

\section{Cat. 103}

Ephesos lamp

Date and place of find: 06. 06. 2000, dromos.

Fragment of shoulder and discus. Black gray glaze. Egg rows separated by floral motifs at shoulder.

Cf.: -

Date: $125-80$ BC

\section{Cat. 104}

pl. 28

Unguentarium Base (?)

Date and place of find: 06. 06. 2000, dromos.

Lower body and base fragment. Wide flaring body with short conical base. Plain, made out of yellow clay.

Cf.: -

Date: -

Cat. 105

pl. 28

Ephesos lamp

Date and place of find: 06. 06. 2000, dromos.

Shoulder and discus fragment. Dark gray-black glaze. Heart shaped ivy leaves on shoulder.

Cf.: -

Date: $125-80 \mathrm{BC}$ 
Group A

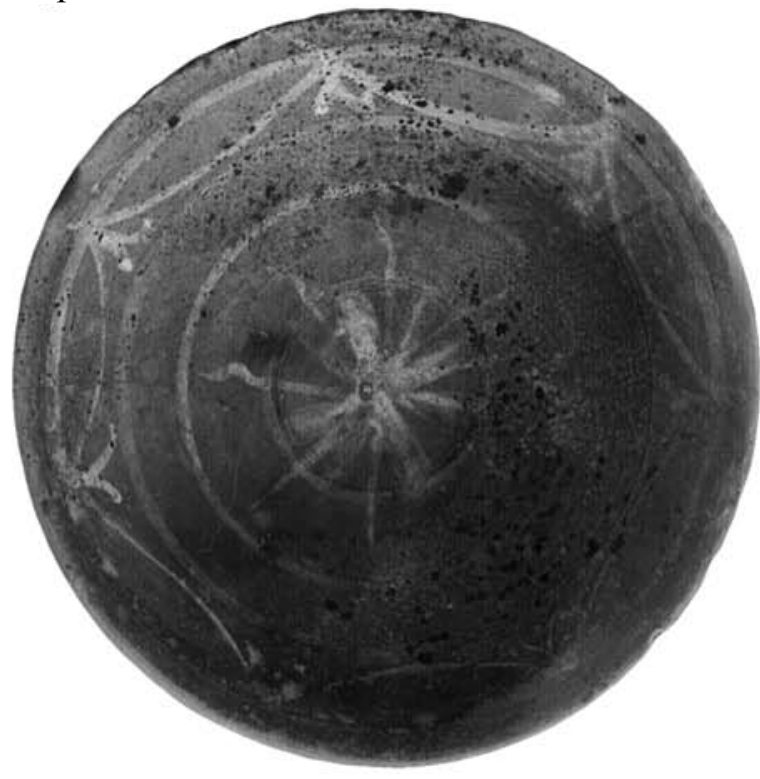

Cat.1

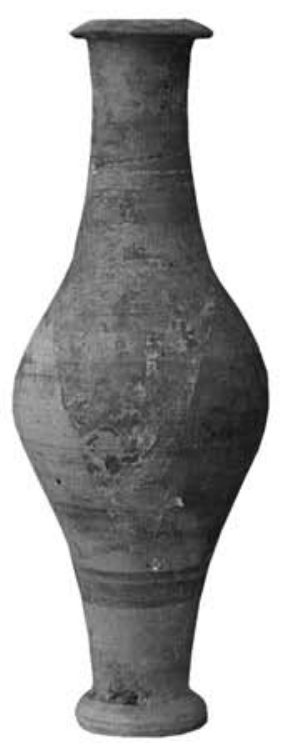

Cat. 3

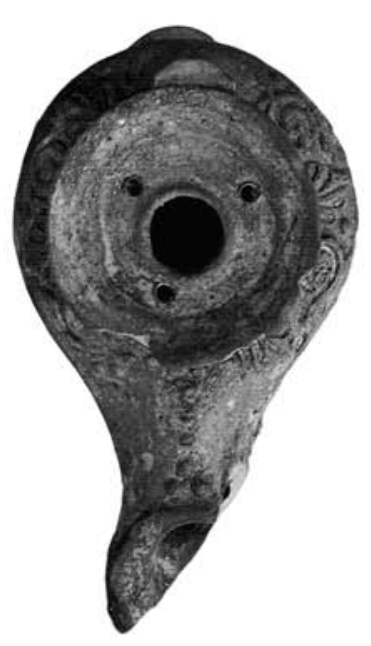

Cat.7

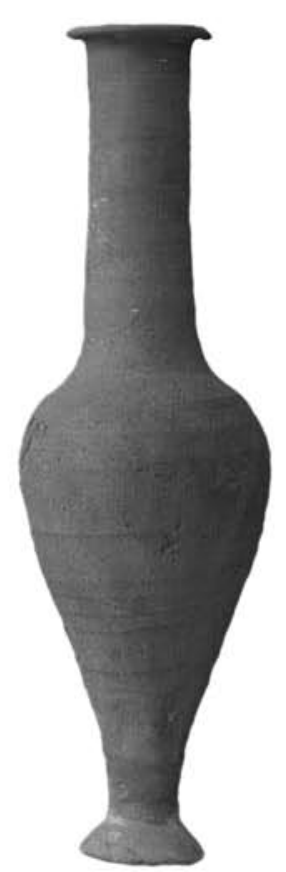

Cat.4

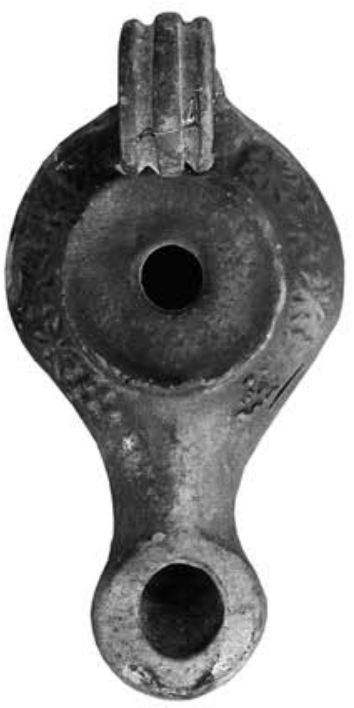

Cat.8
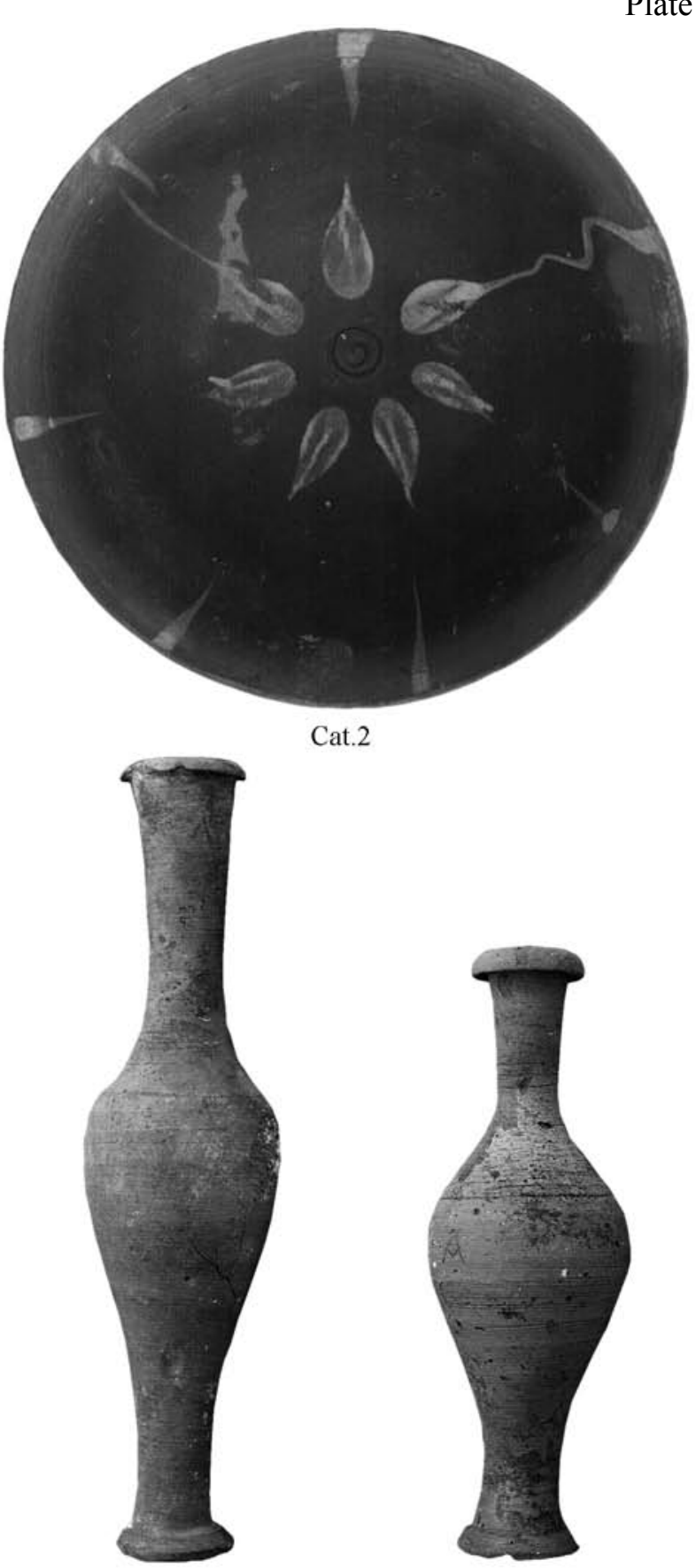

Cat. 5

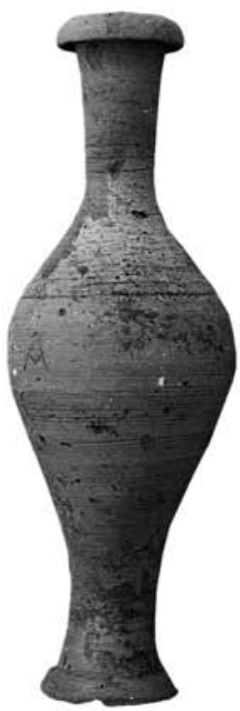

Cat.6

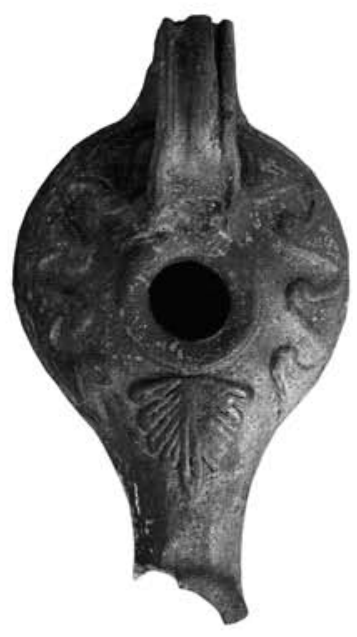

Cat.9

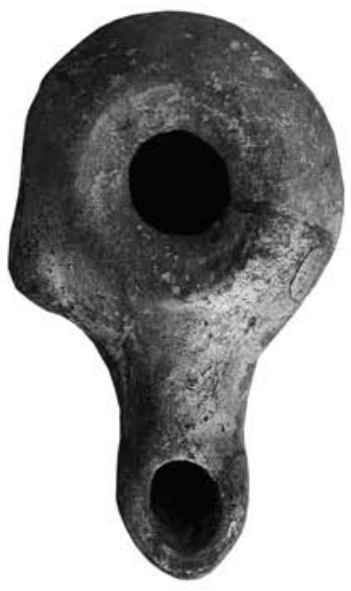

Cat.10 
Plate 2
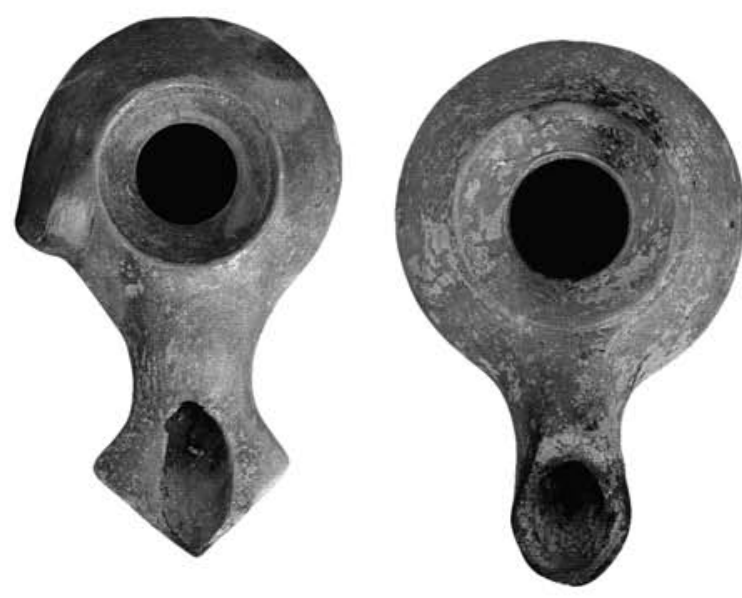

Cat.12

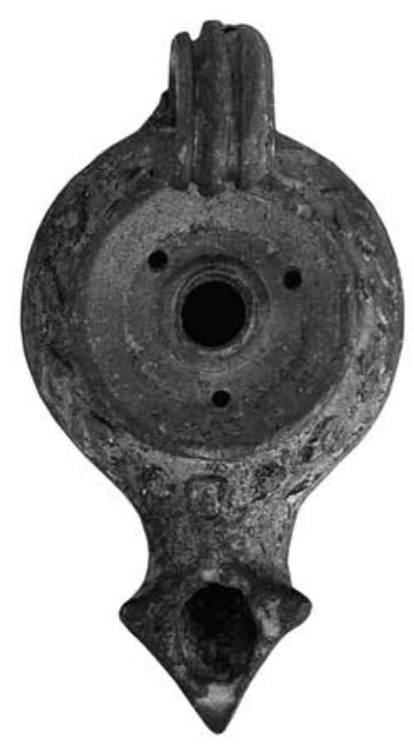

Cat.13

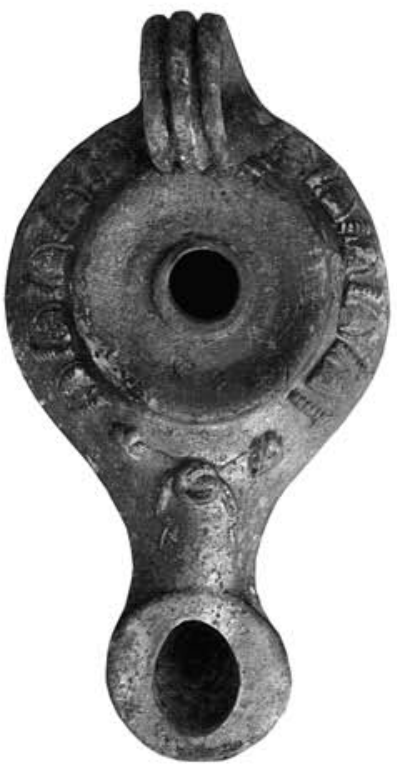

Cat. 14

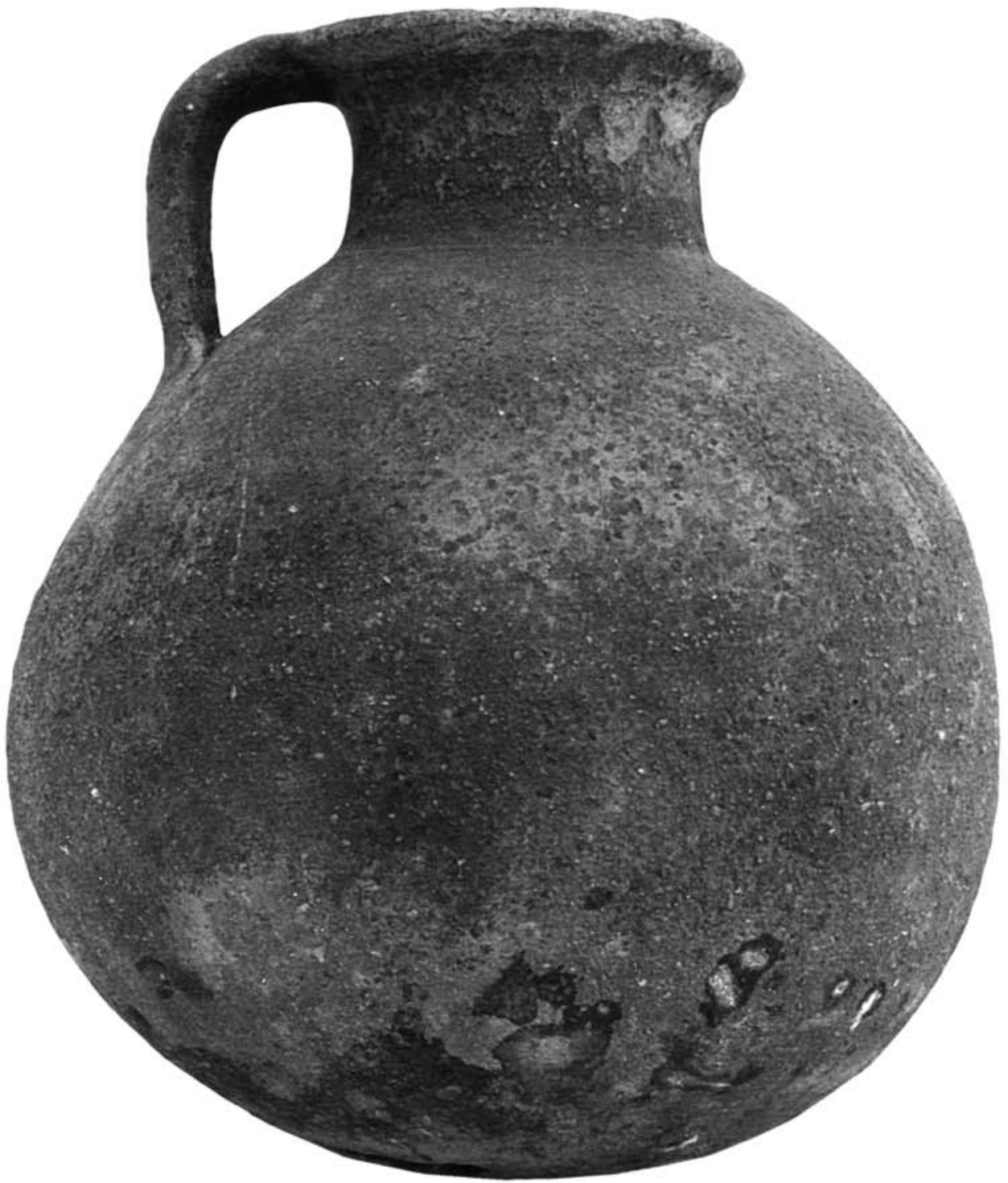

Cat.51 

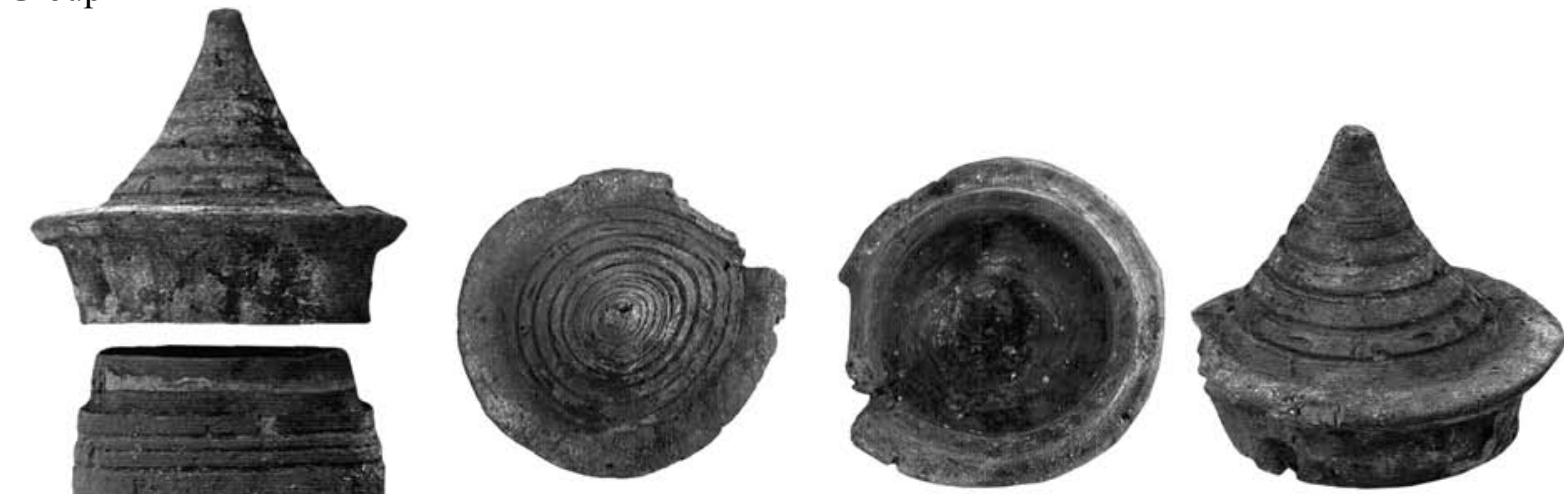

Cat.89
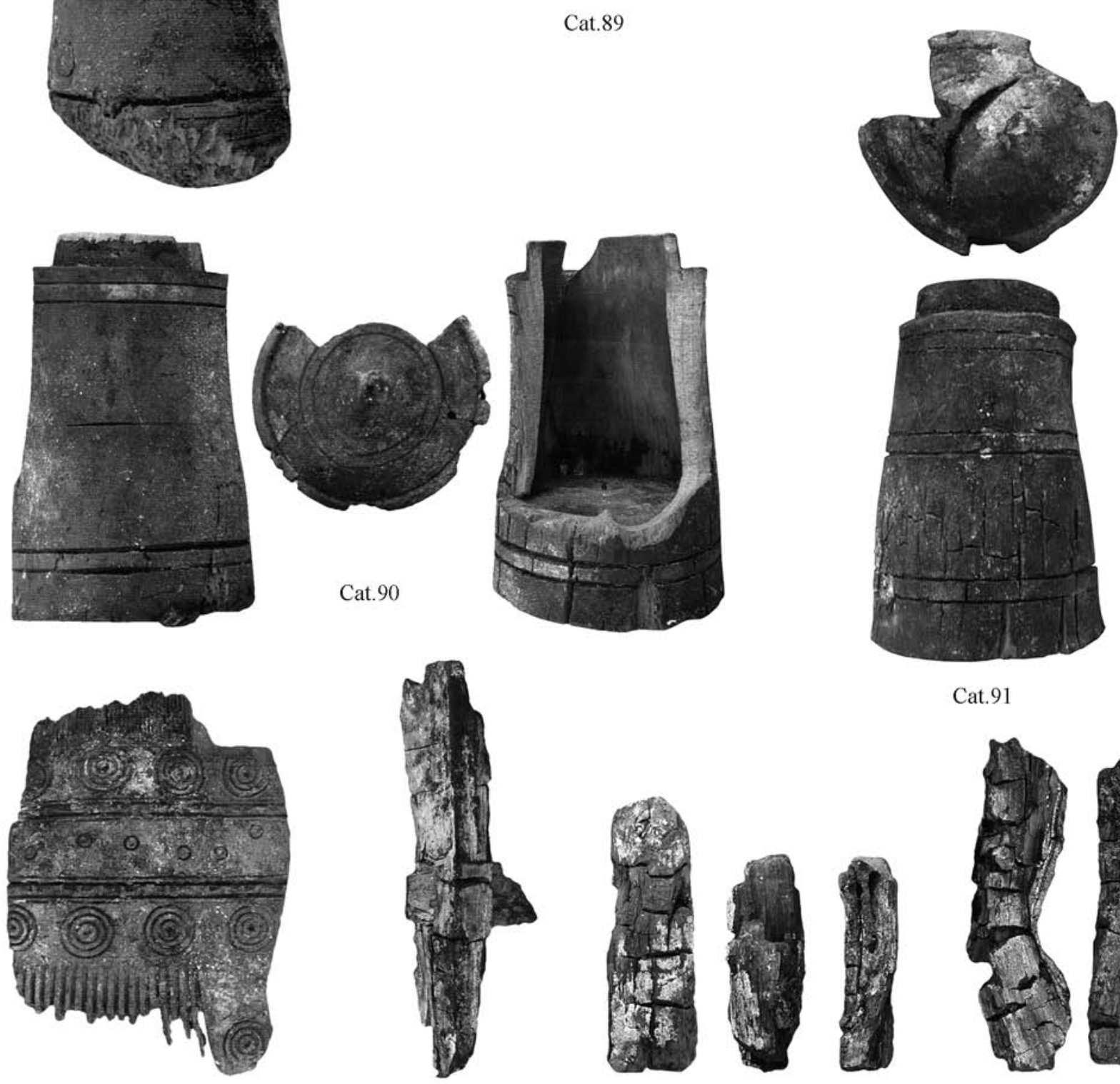

Cat.91

Cat.92

Cat. 93 a

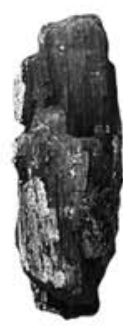

Cat. 93 b

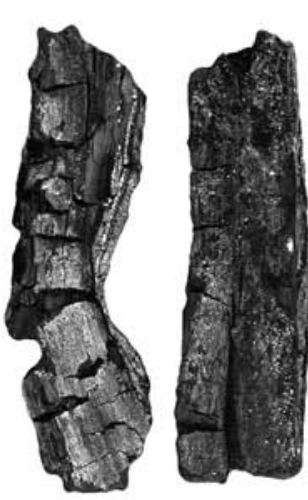

Cat. $93 \mathrm{c}$

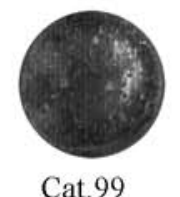

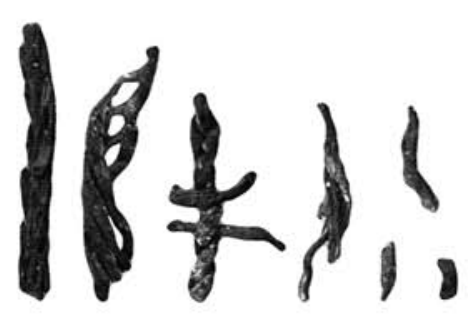

Cat.94

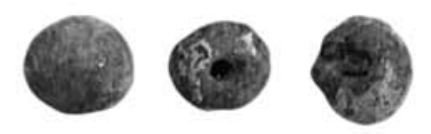

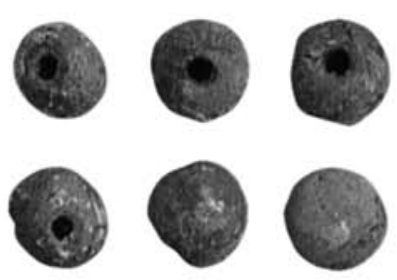

Cat.97 

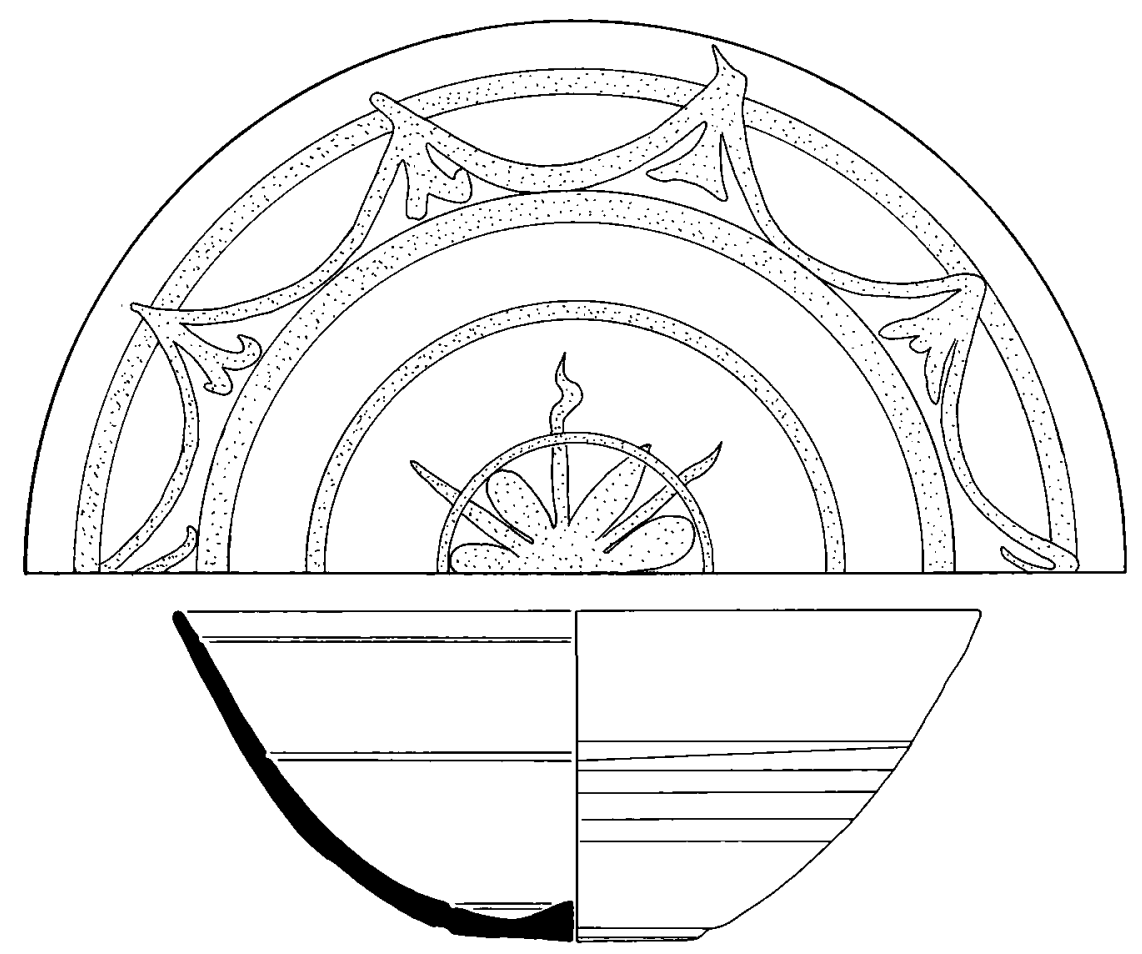

Cat.1
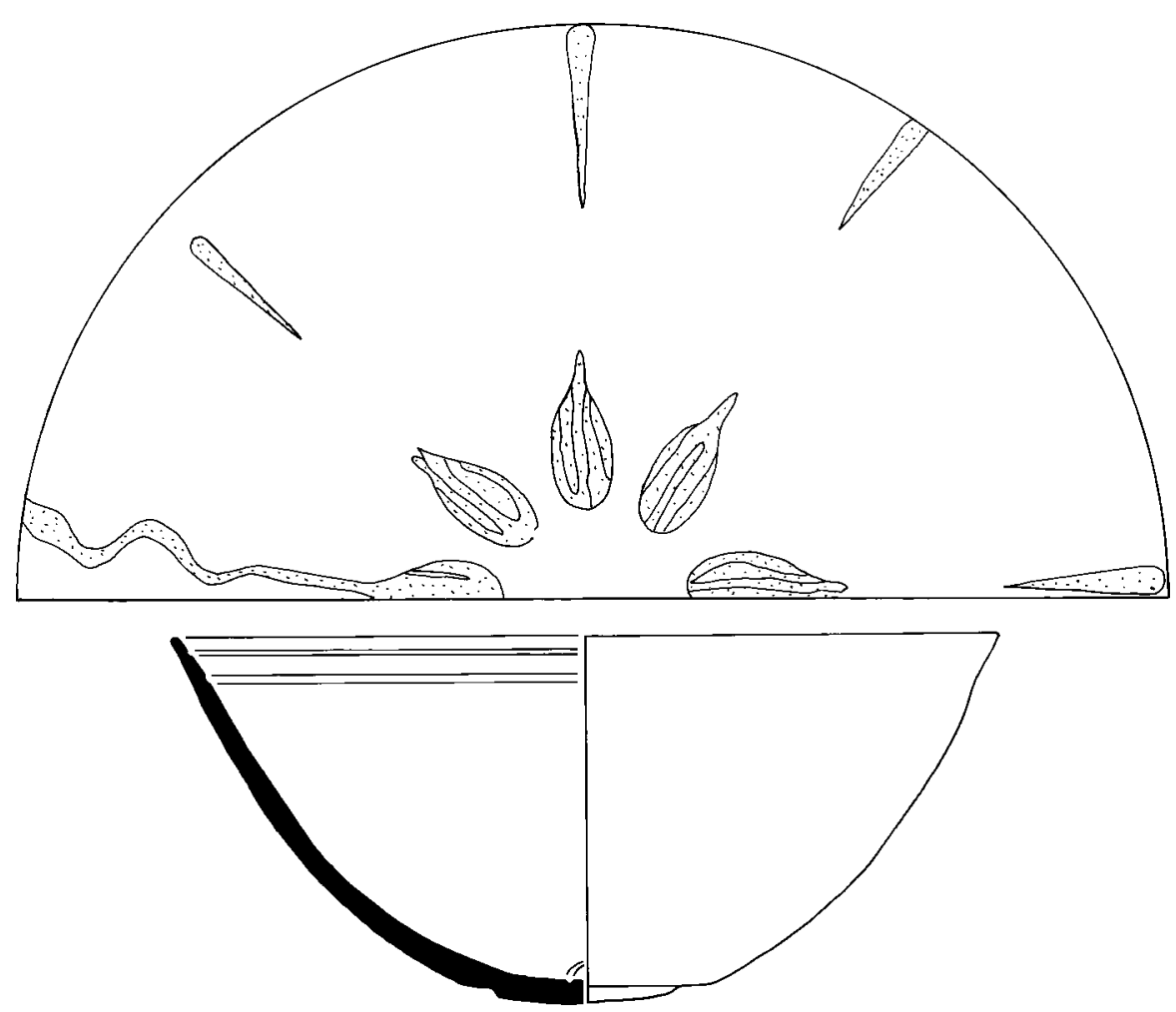

Cat.2

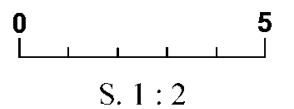



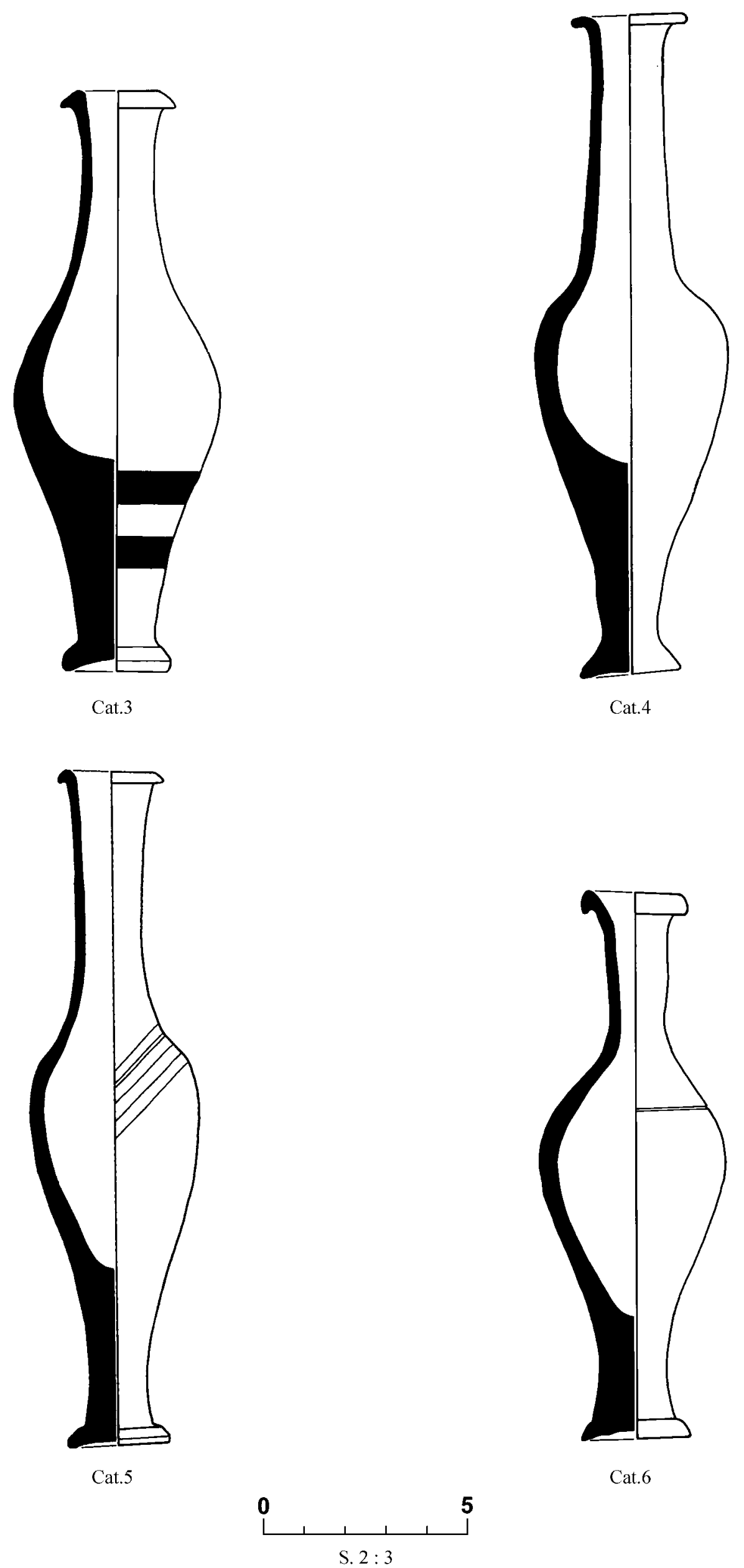

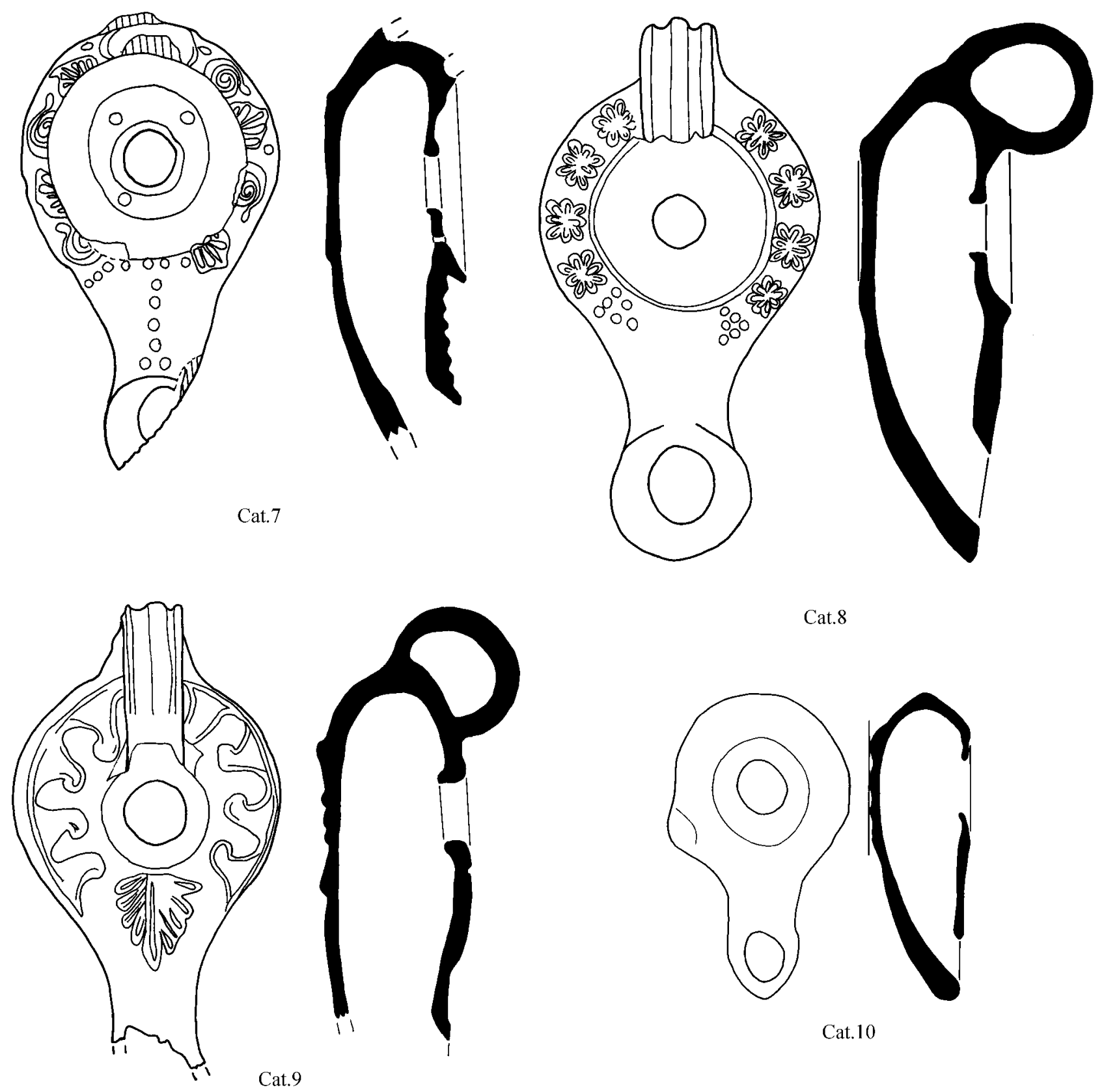

Cat. 8

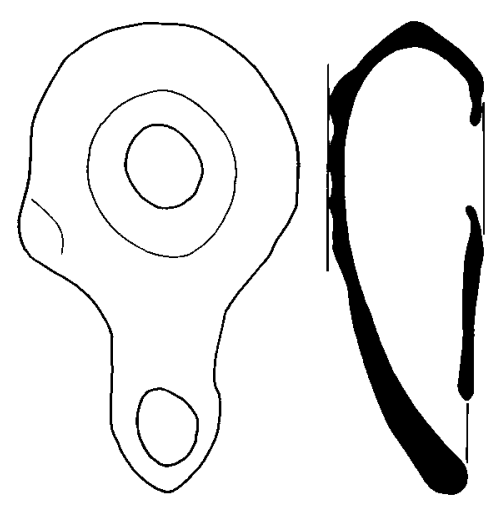

Cat. 10

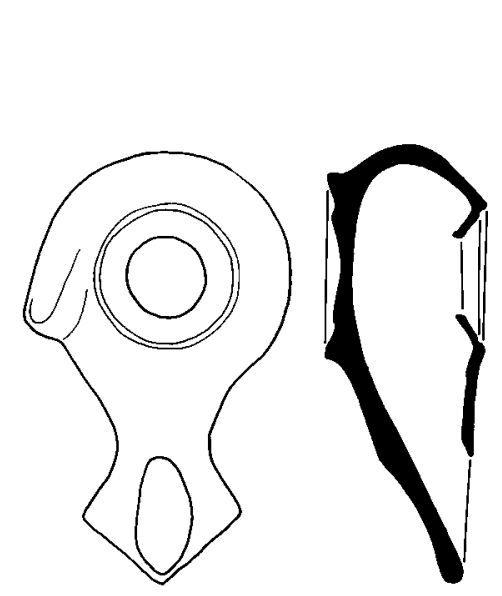

Cat. 11

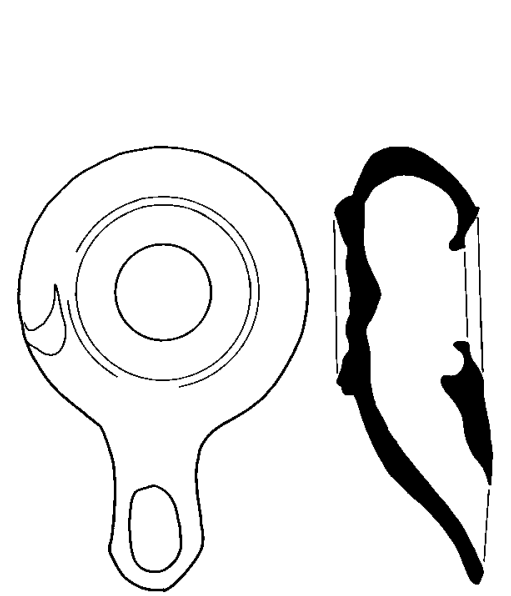

Cat. 12

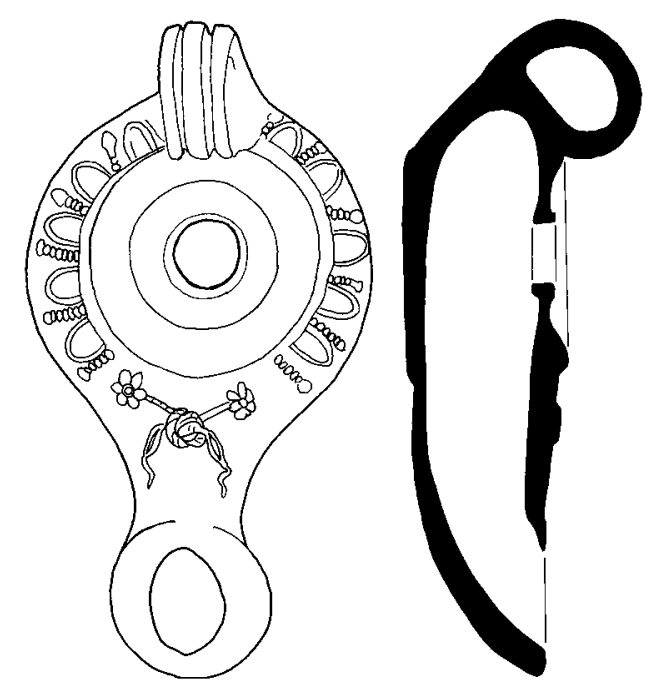

Cat. 14

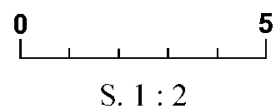




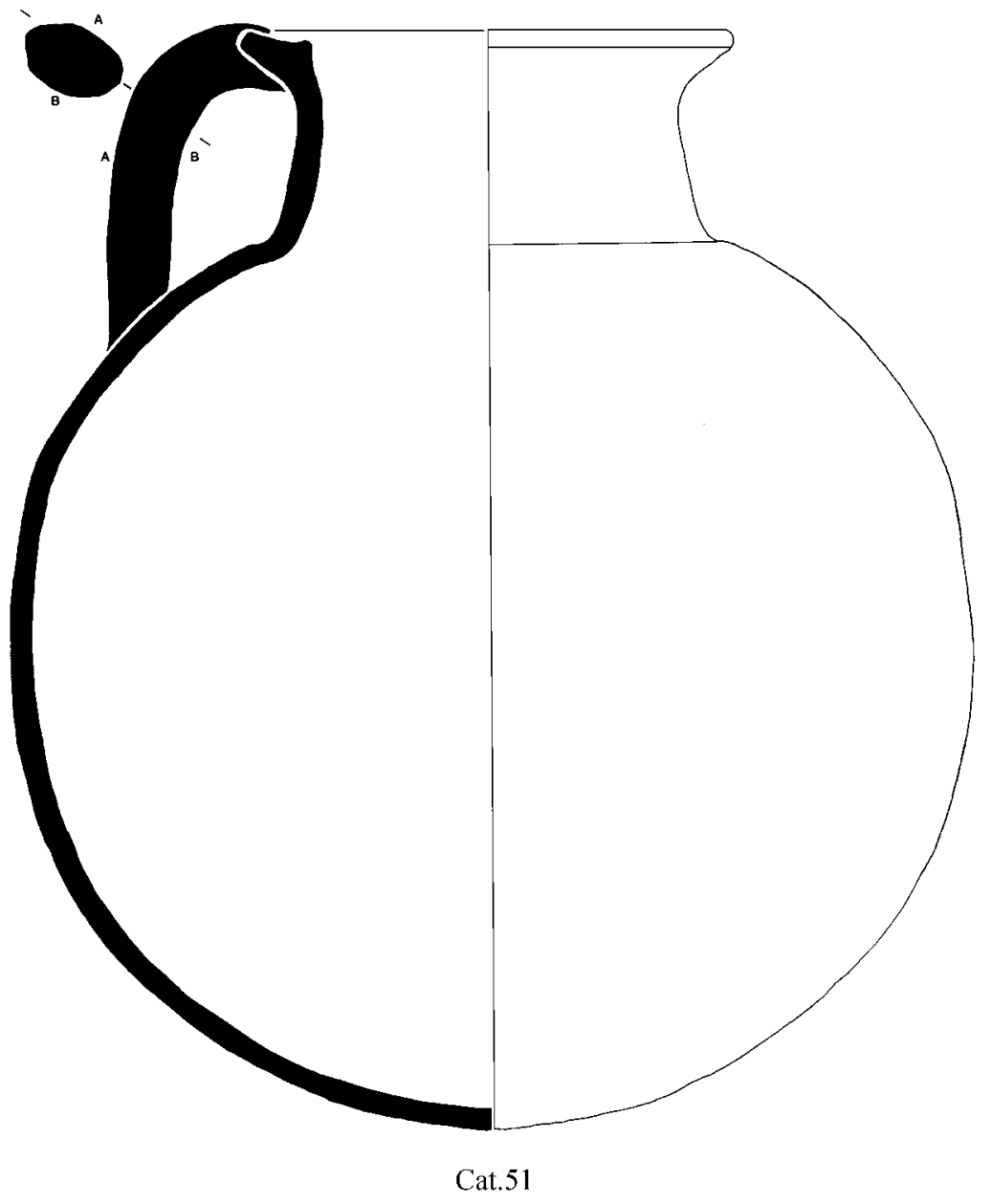

0 5

S. $1: 3$ 
Plate 8

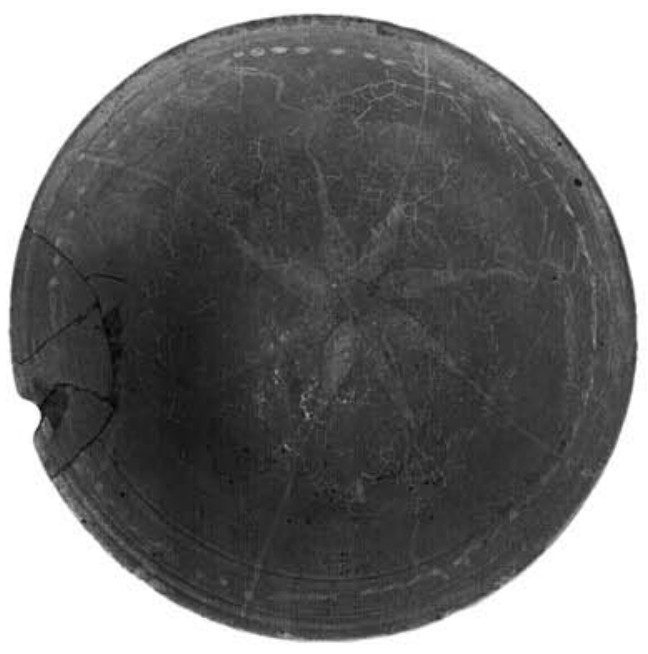

Cat. 15

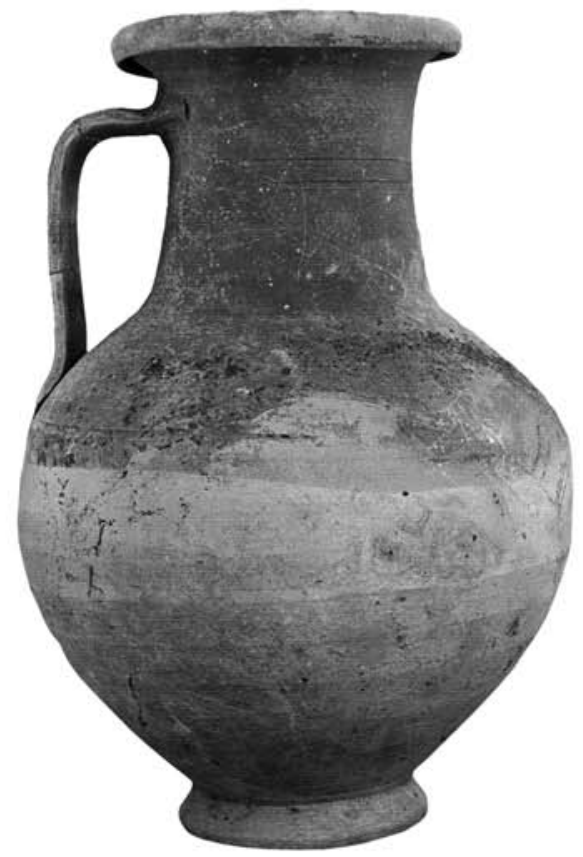

Cat.17

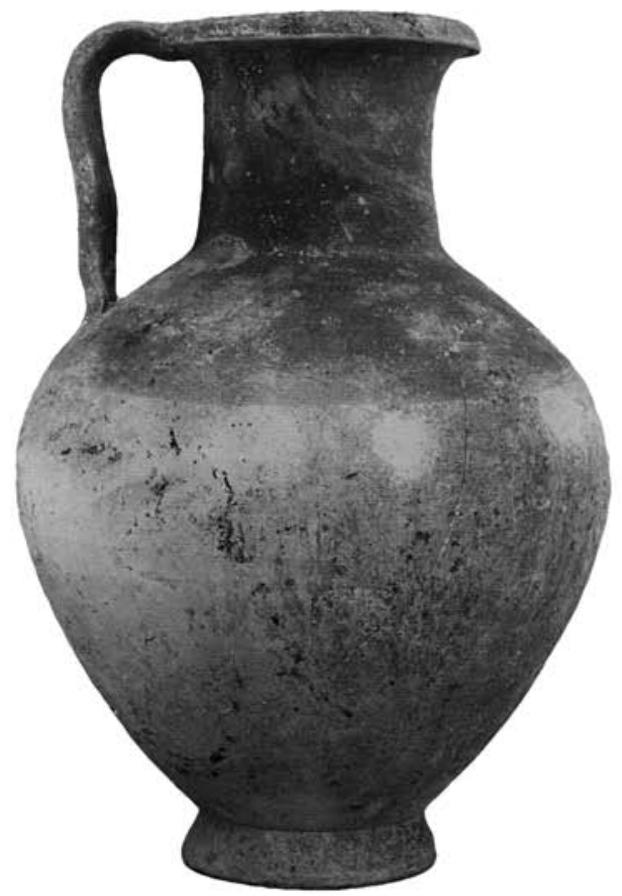

Cat.19

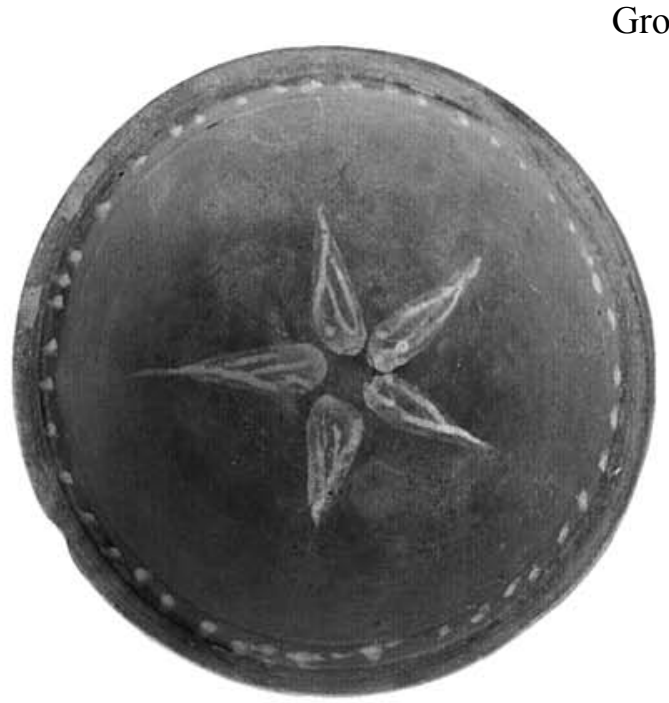

Cat.16
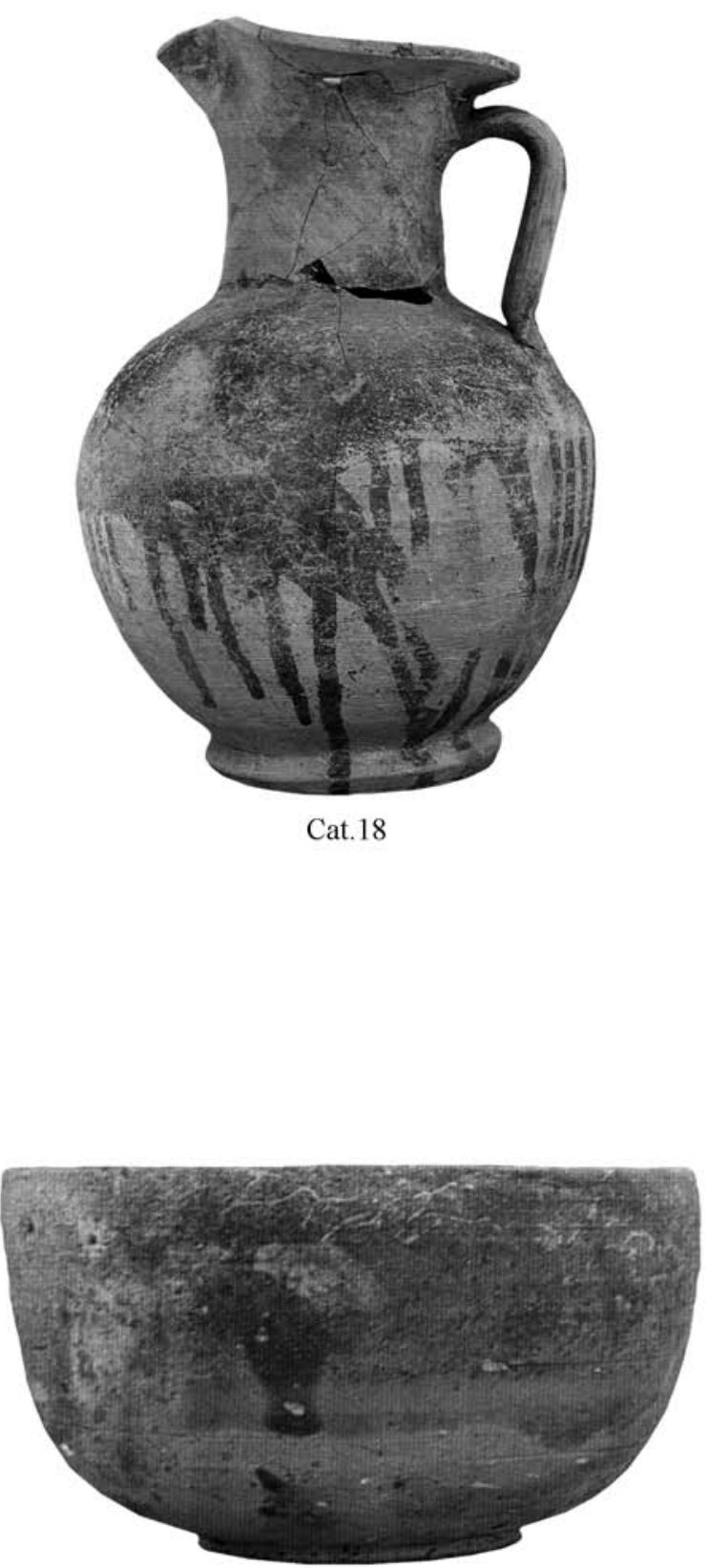

Cat.20 Group B 
Group B

Plate 9

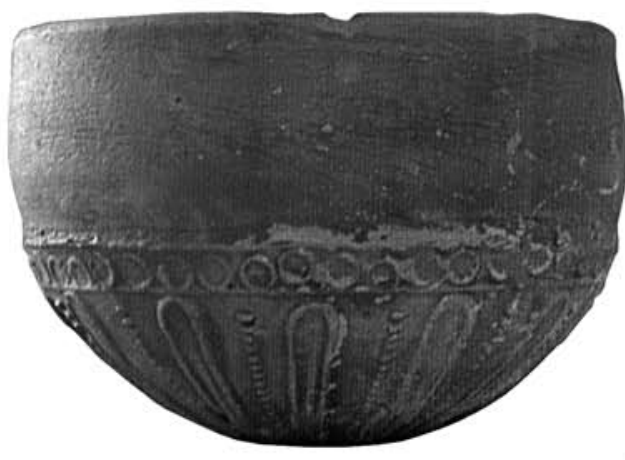

Cat.21
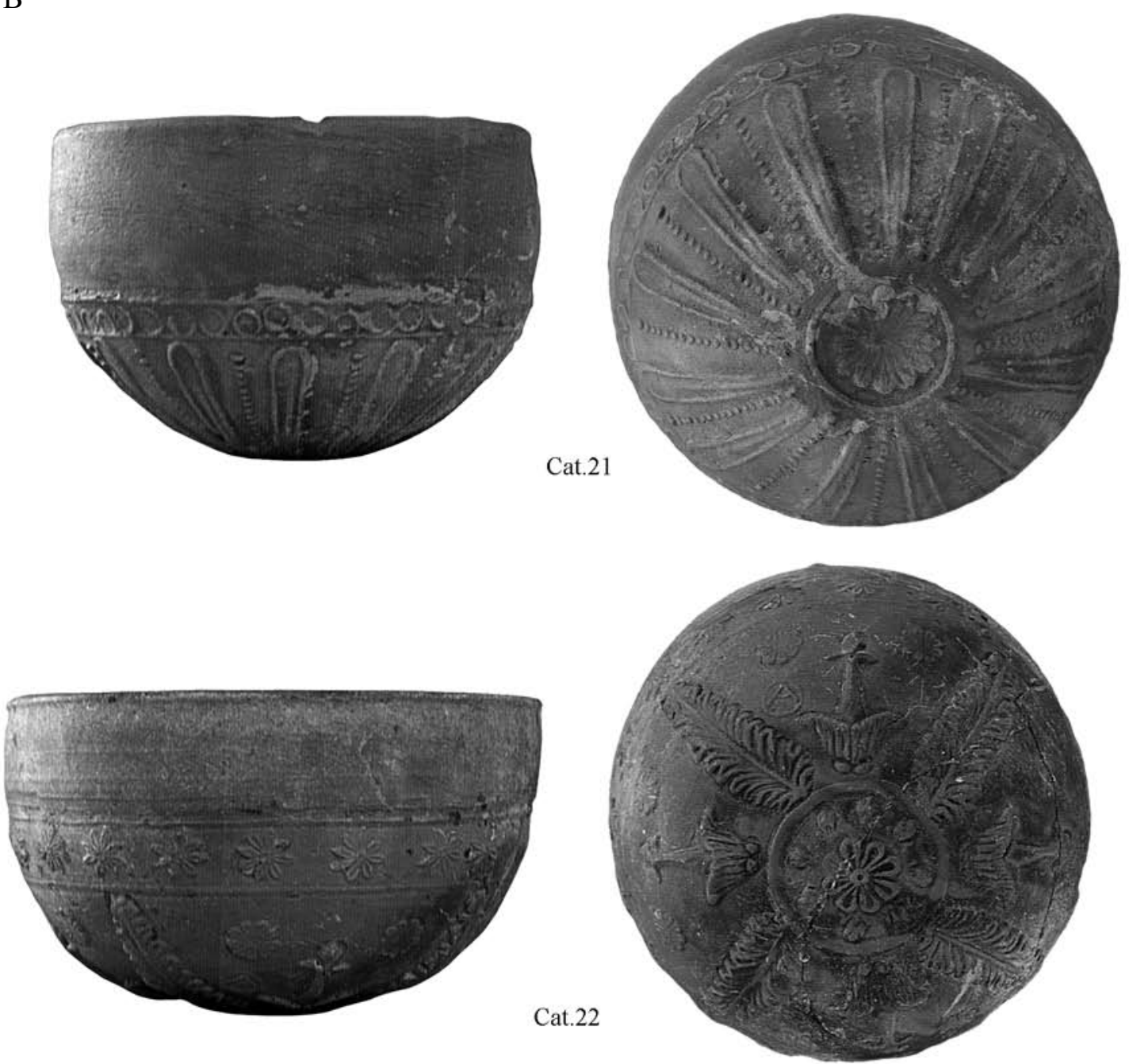

Cat.22

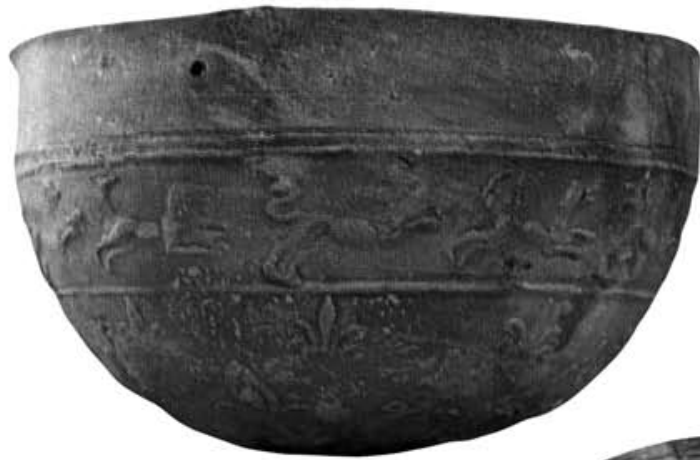

Cat.23

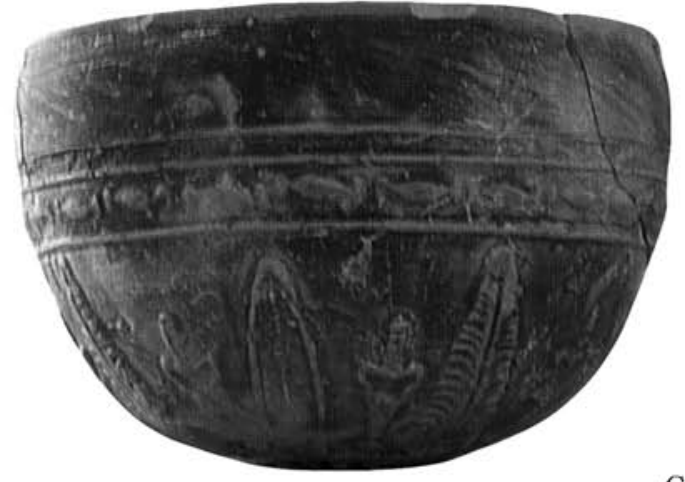

Cat.24

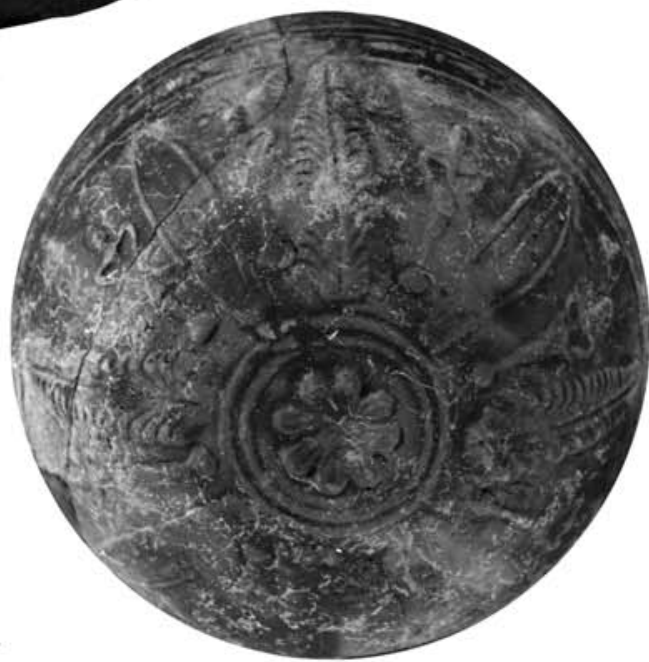


Plate 10
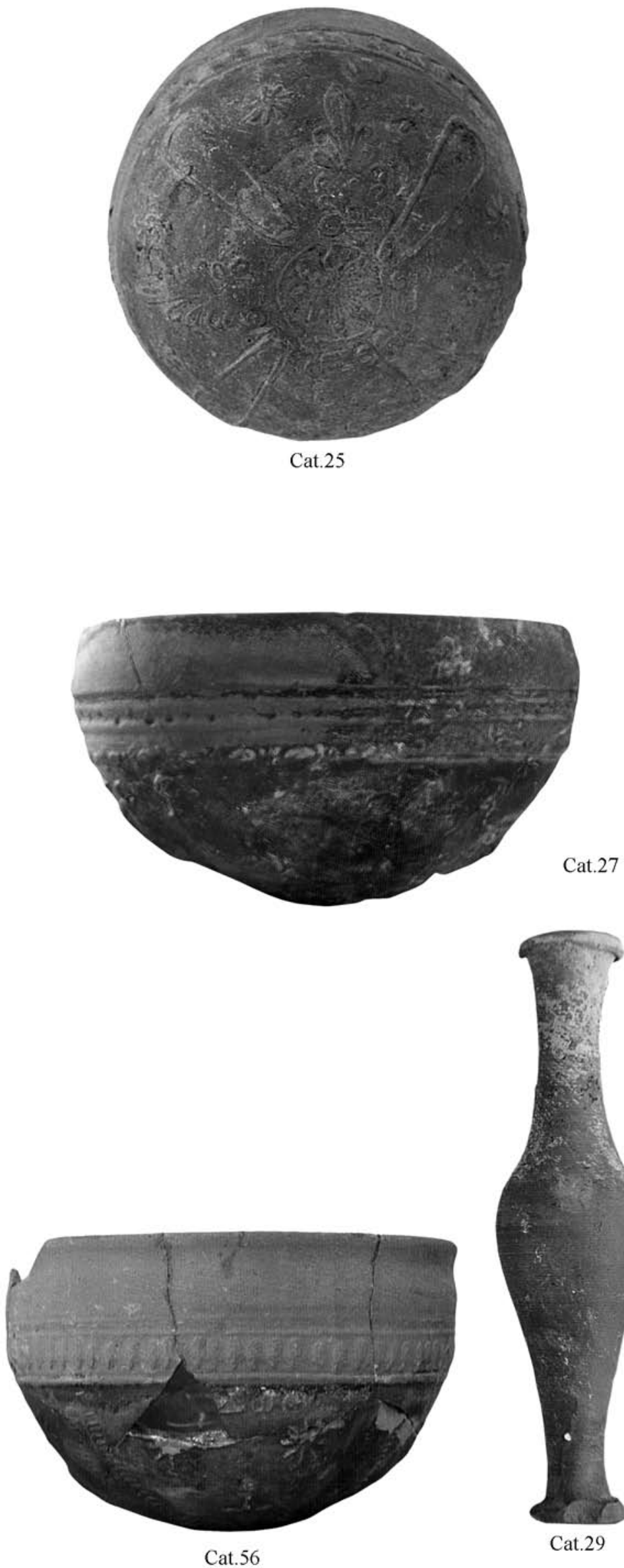

Group B
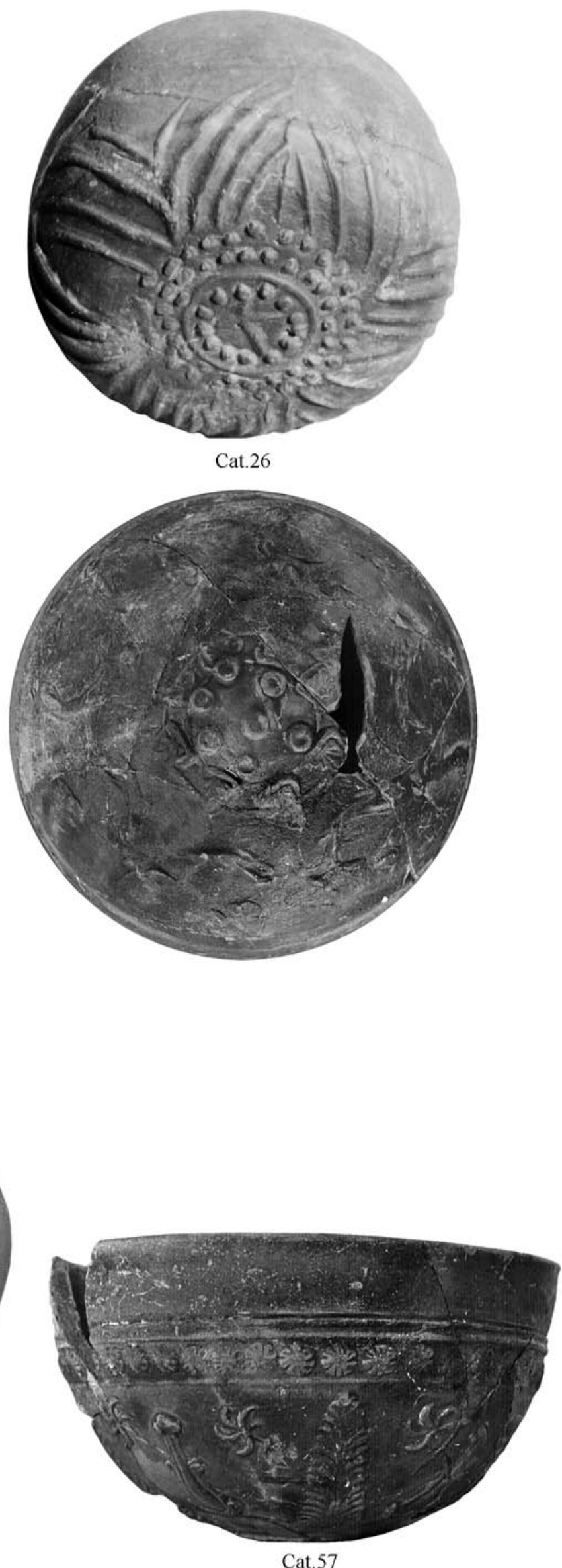

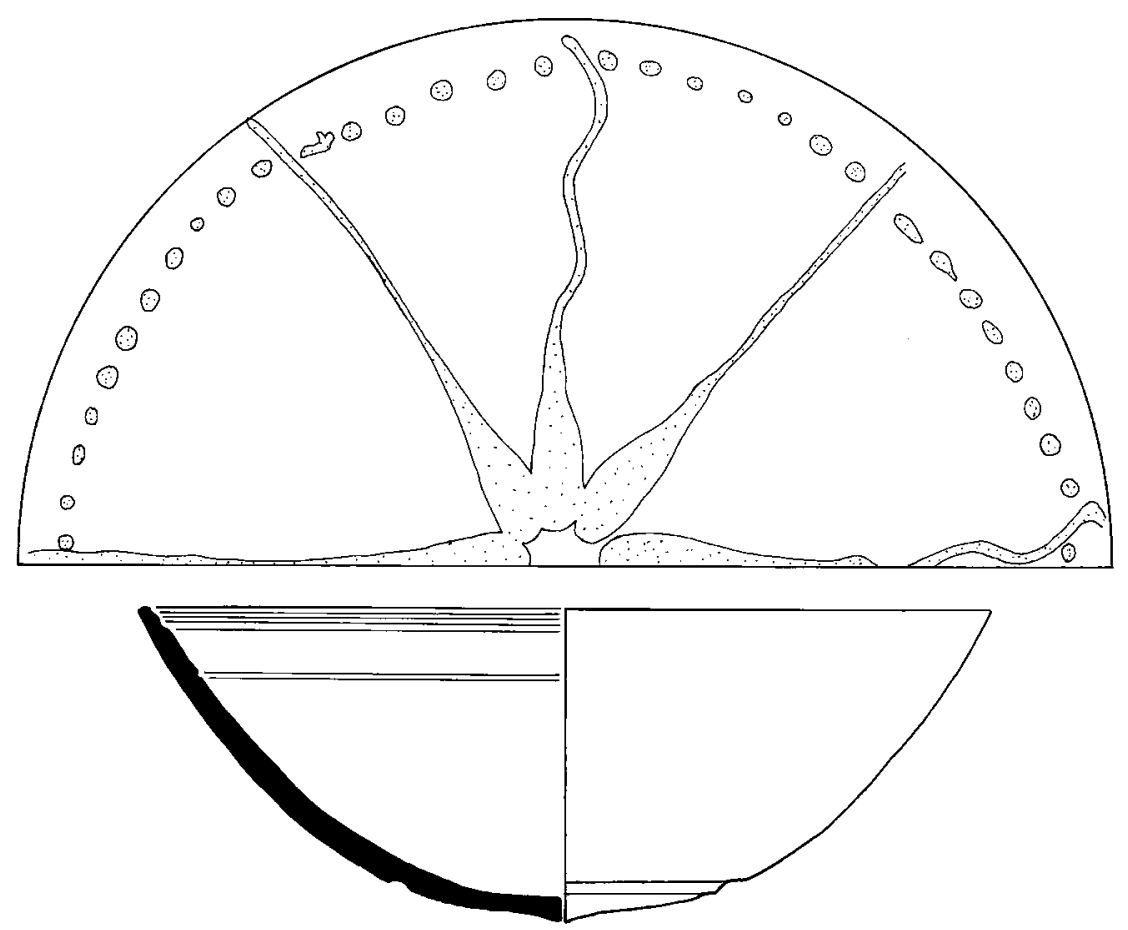

Cat. 15
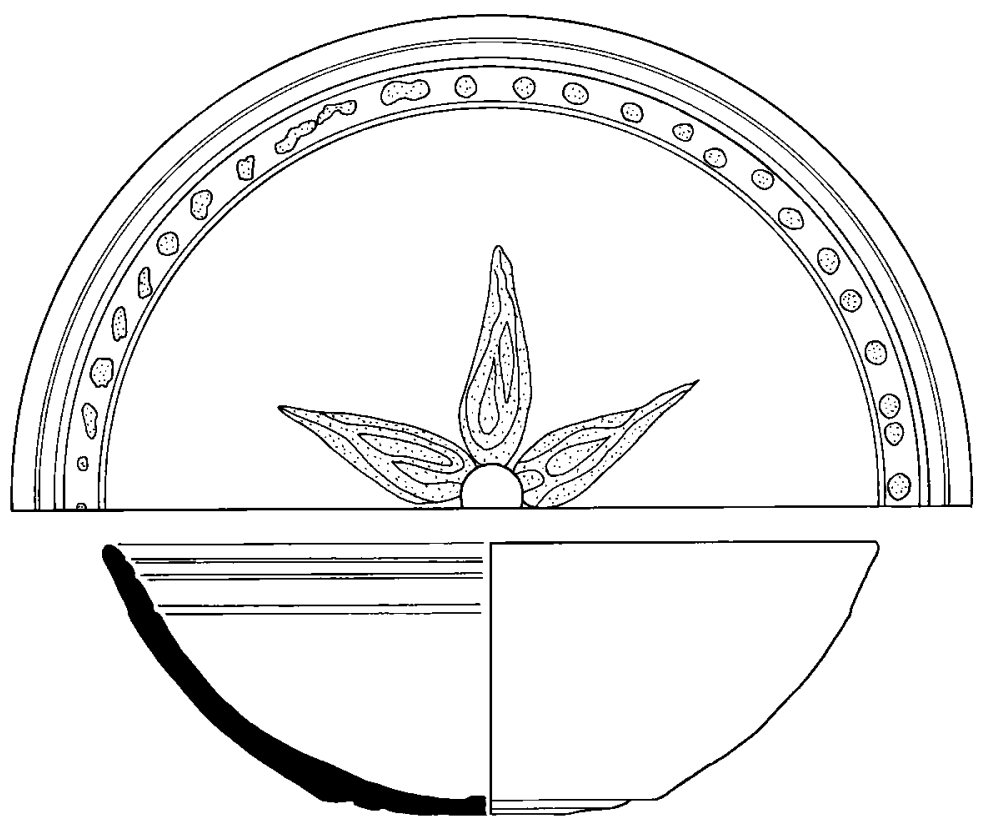

Cat. 16

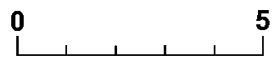

S. $1: 2$ 

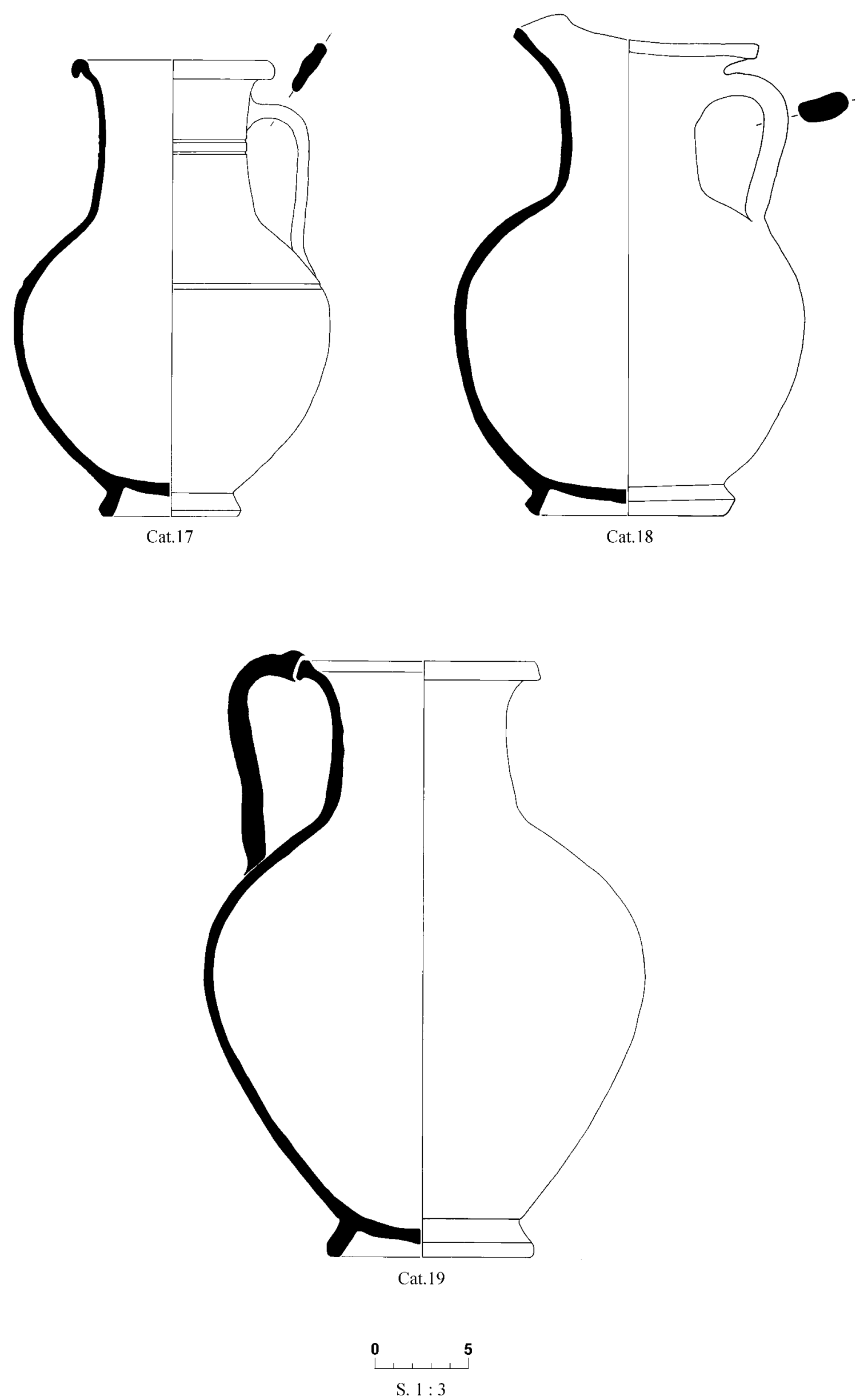


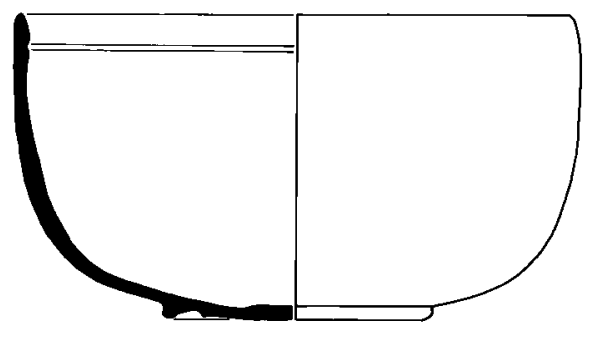

Cat.20
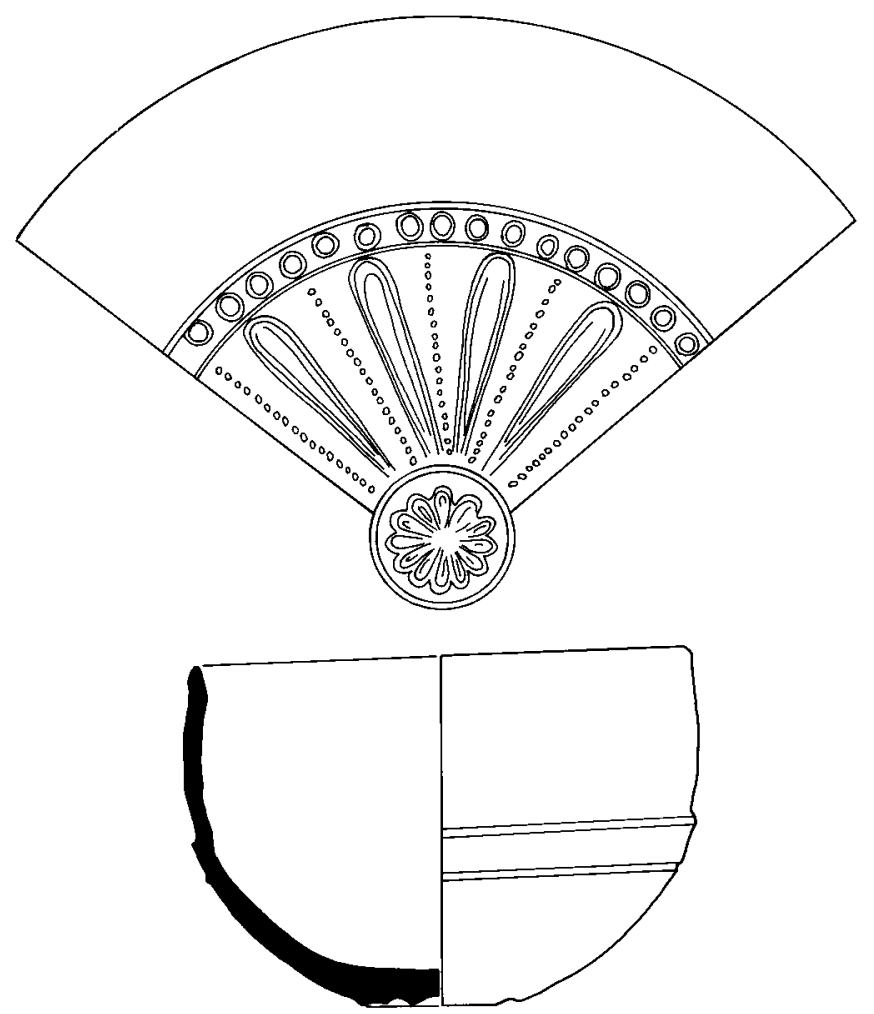

Cat.21
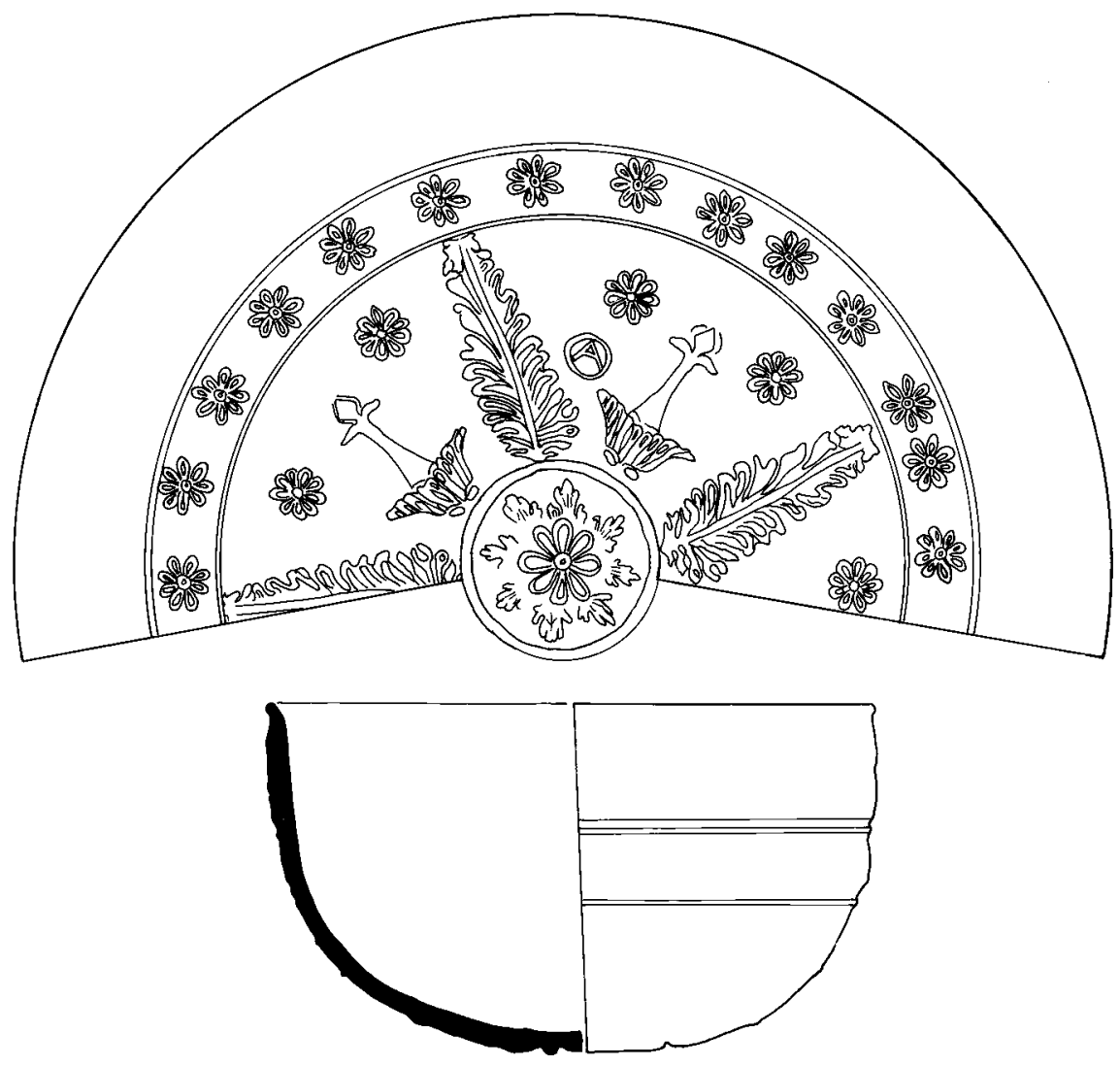

Cat.22

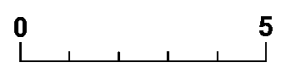

S. $1: 2$ 

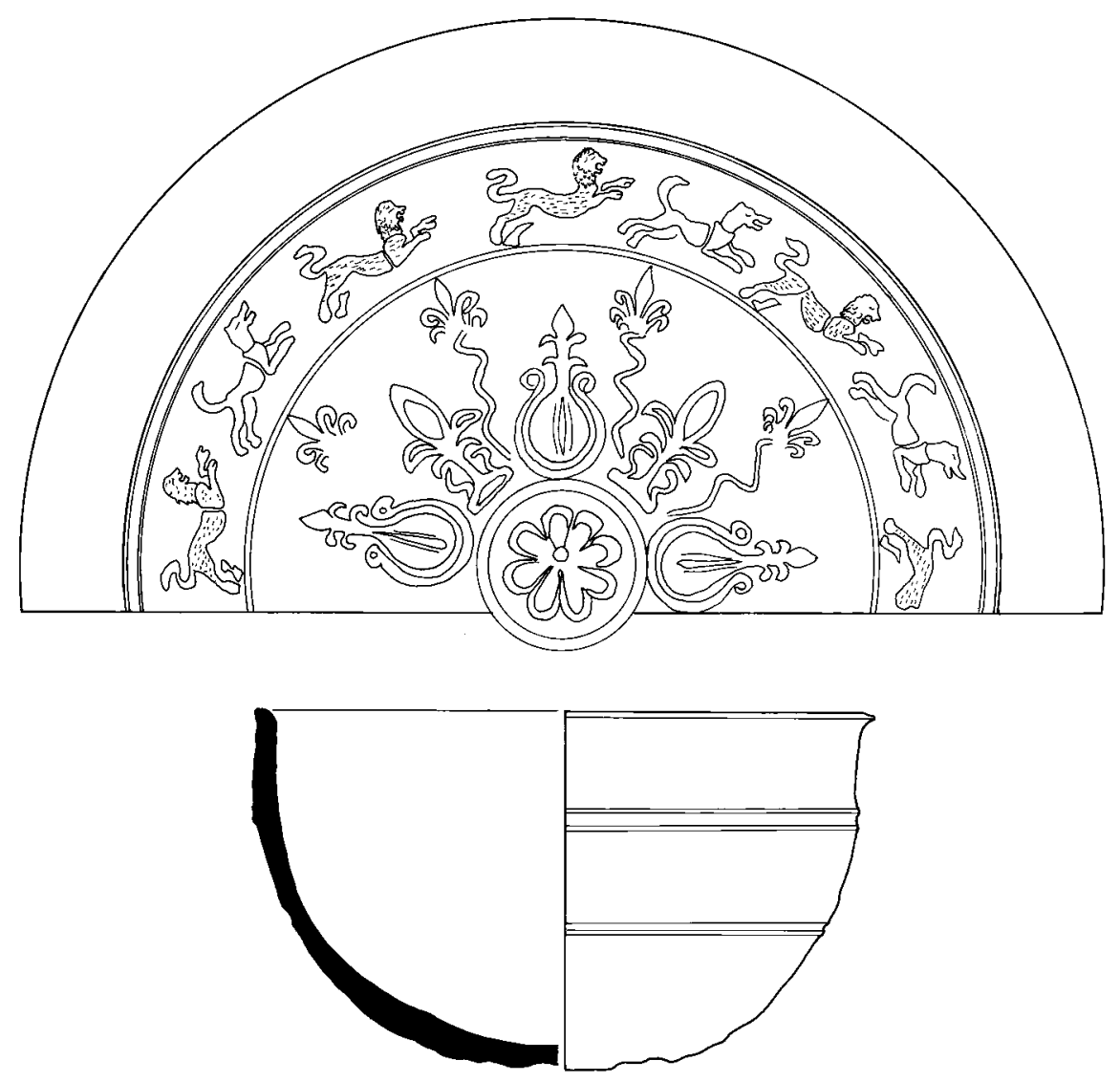

Cat.23
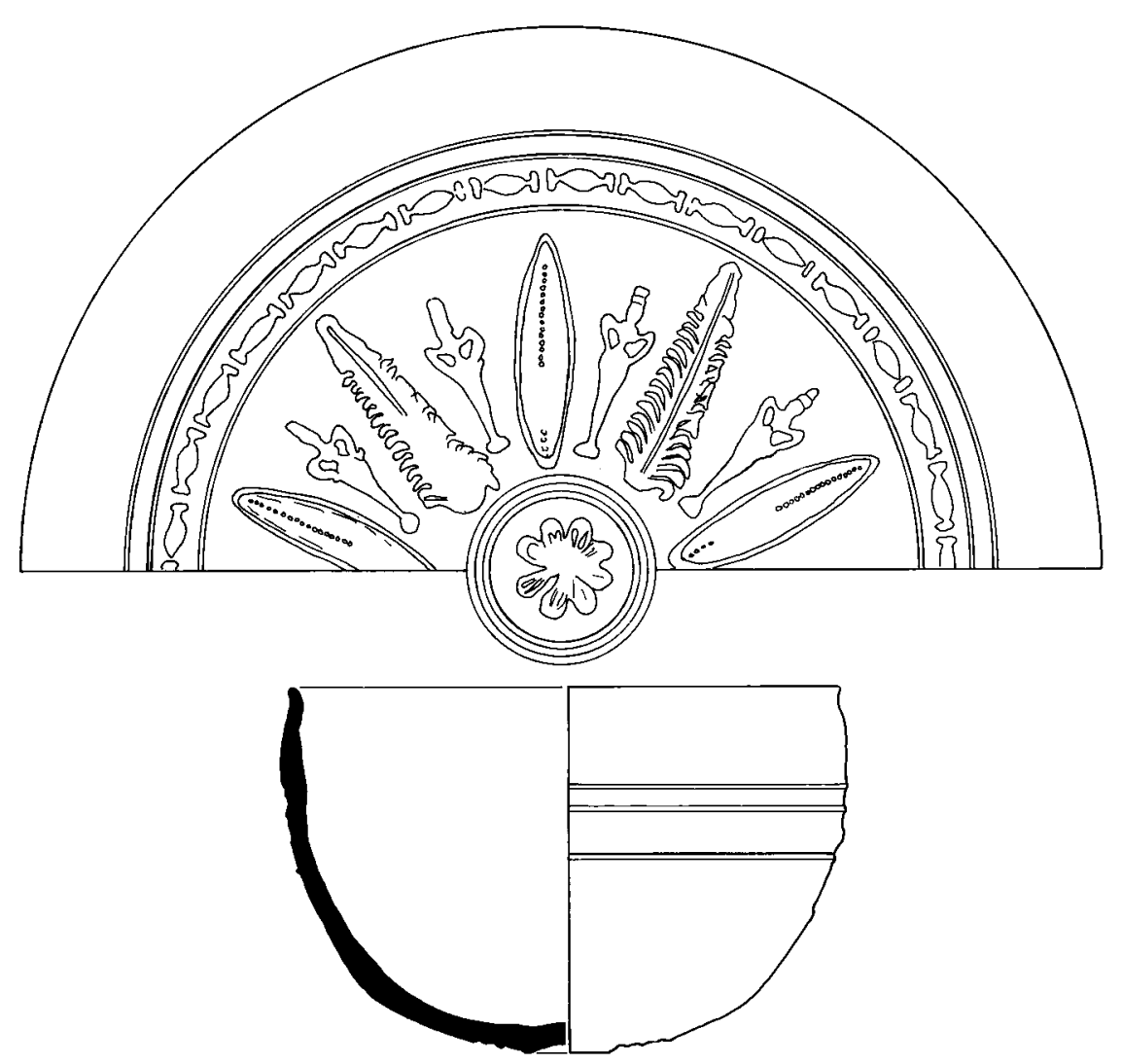

Cat.24

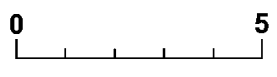

S. $1: 2$ 

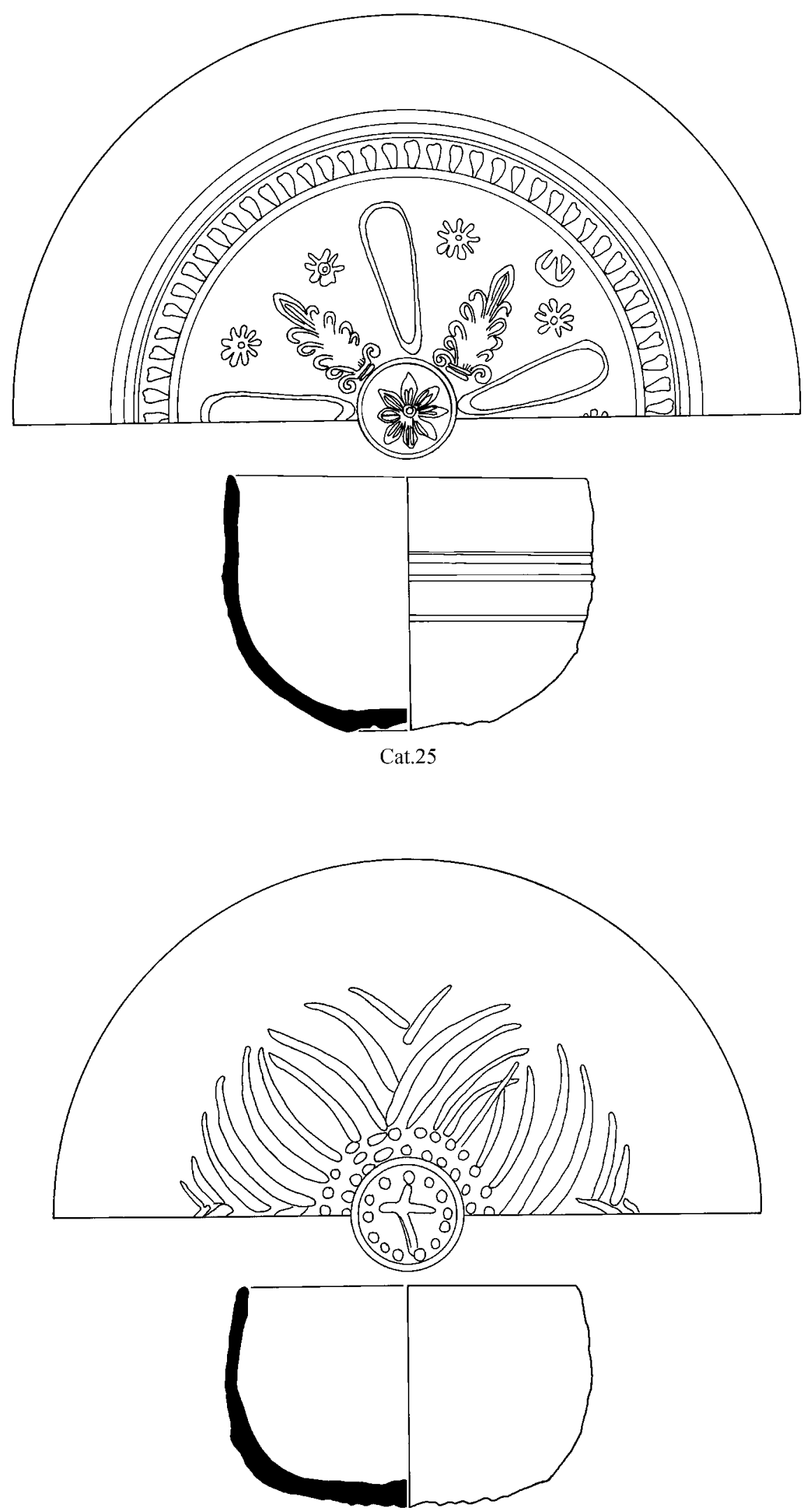

Cat.26

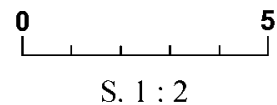


Plate 16
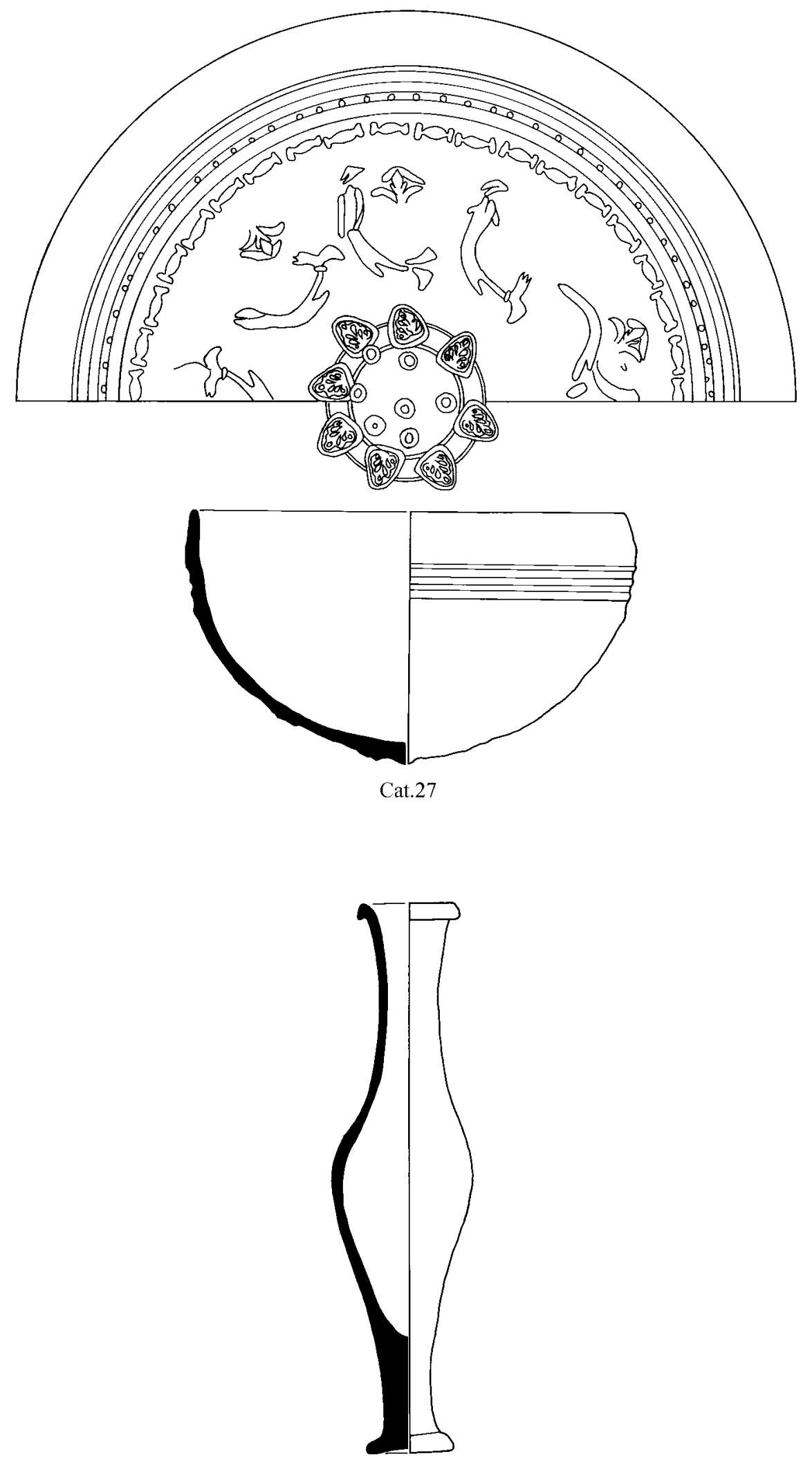

Cat.29

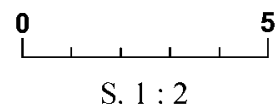



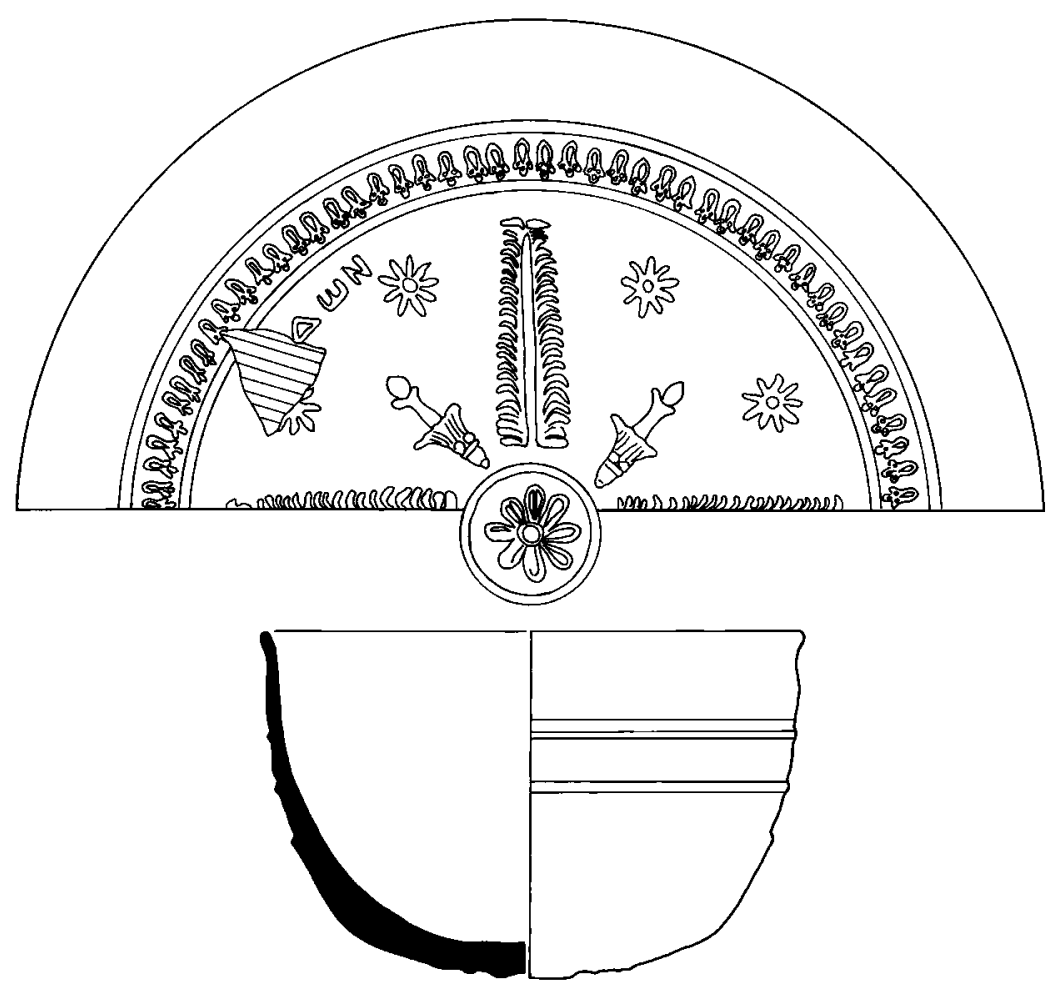

Cat.56
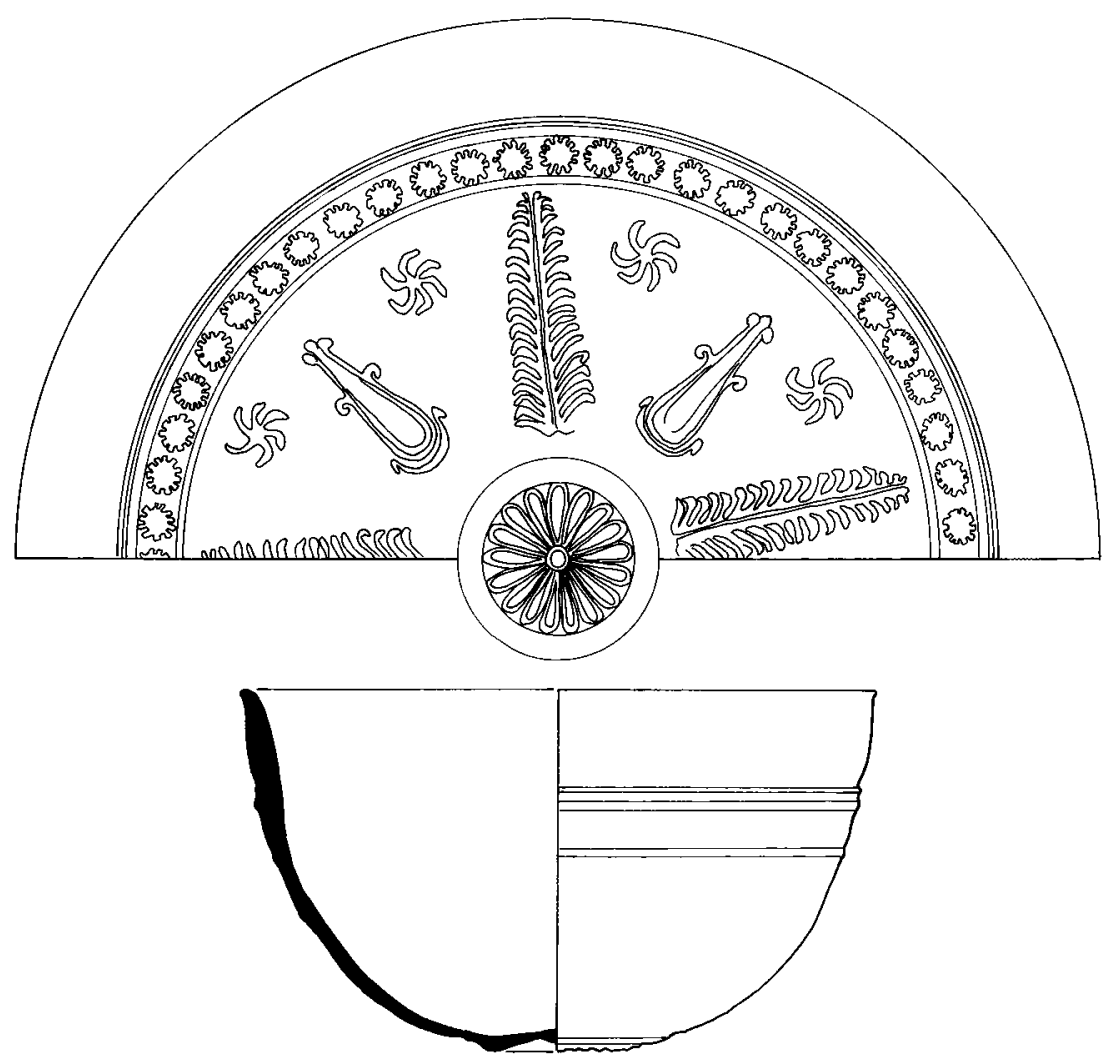

Cat.57

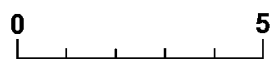

S. $1: 2$ 
Plate 18

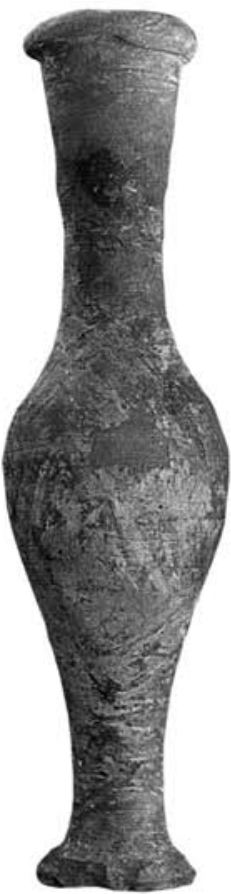

Cat. 30

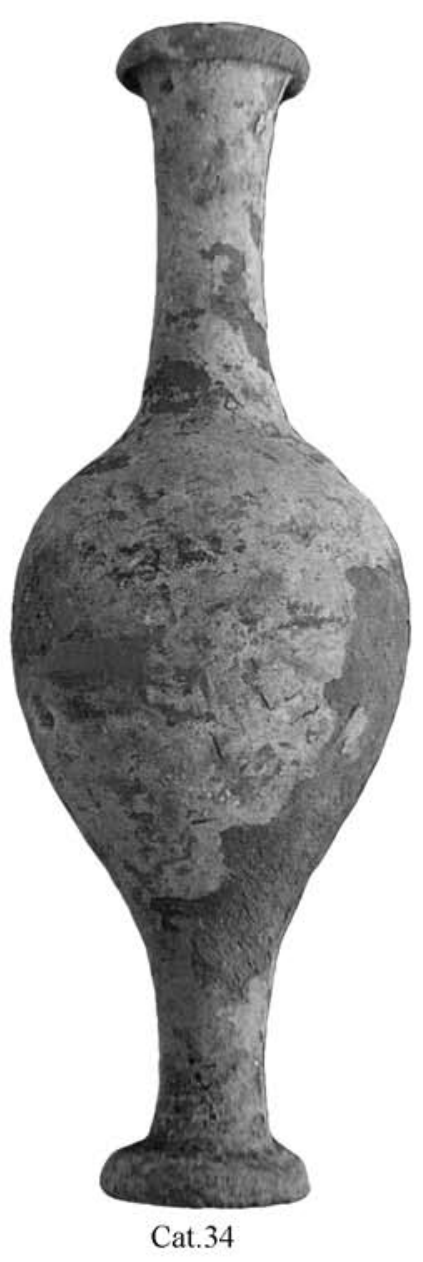

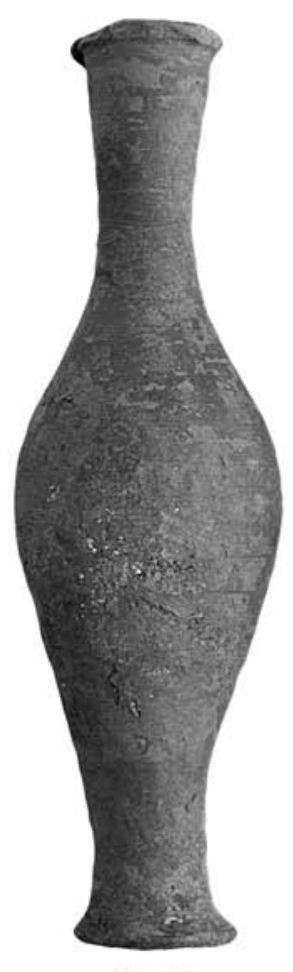

Cat.31

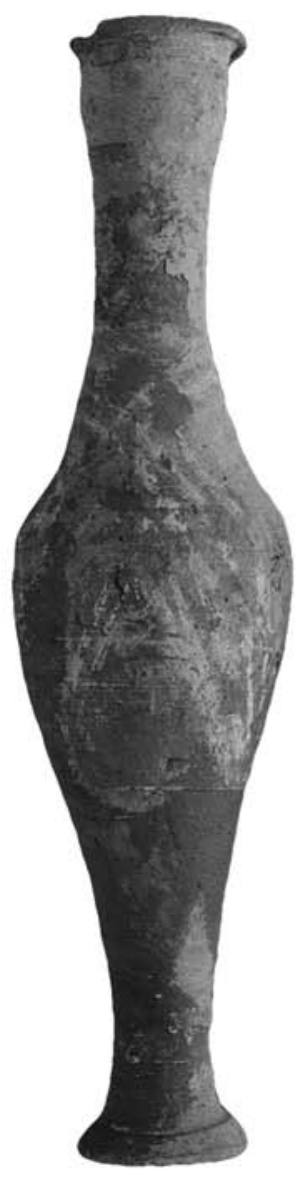

Cat.32
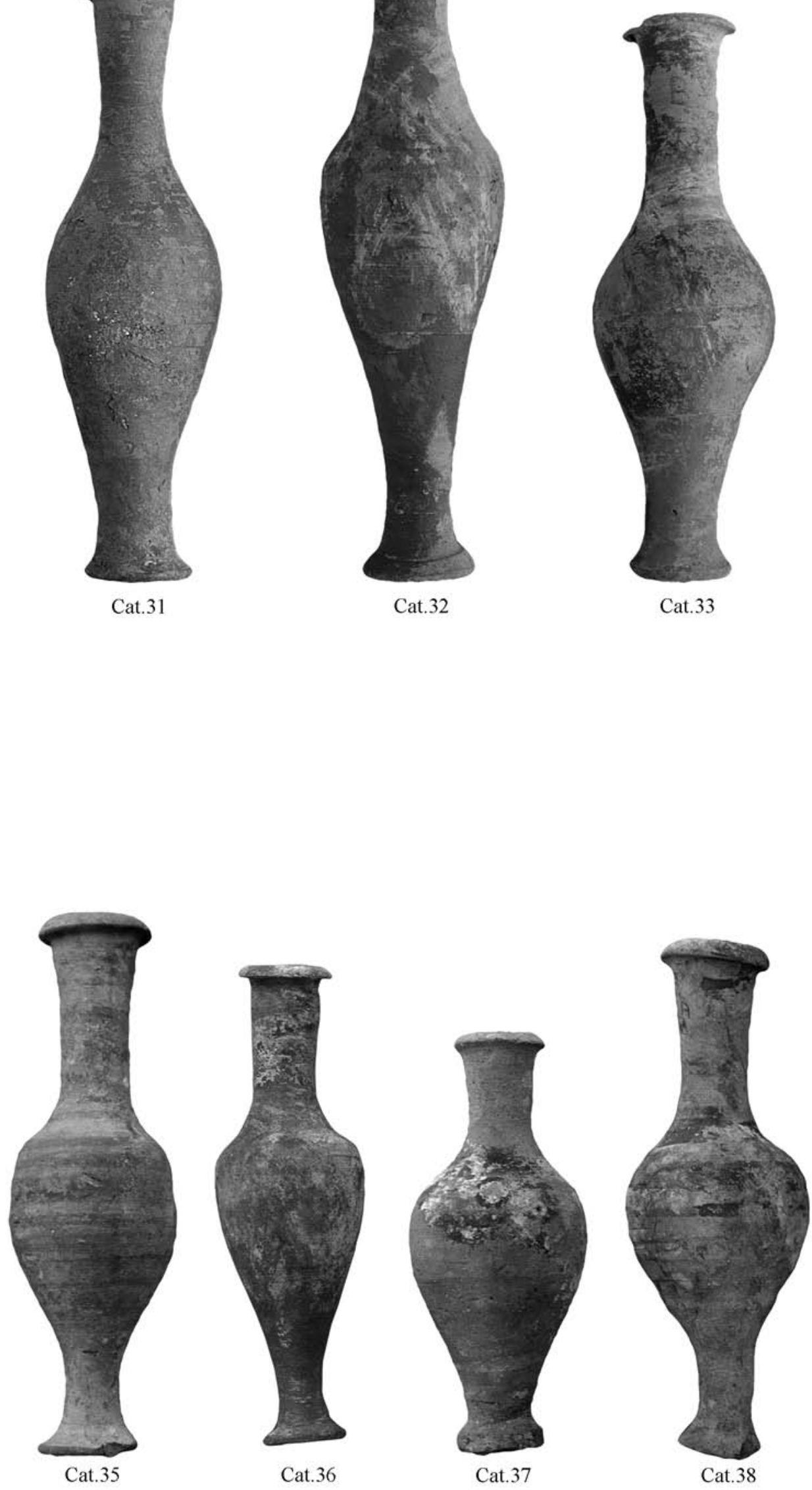
Group C

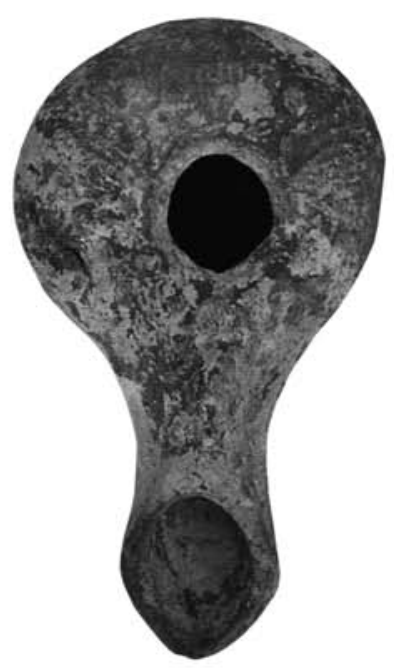

Cat.39

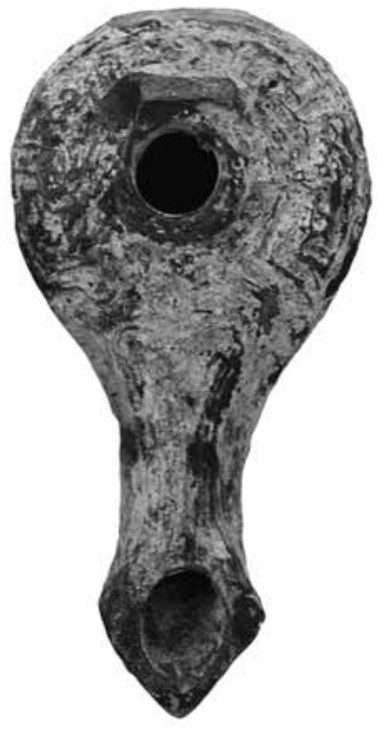

Cat.42

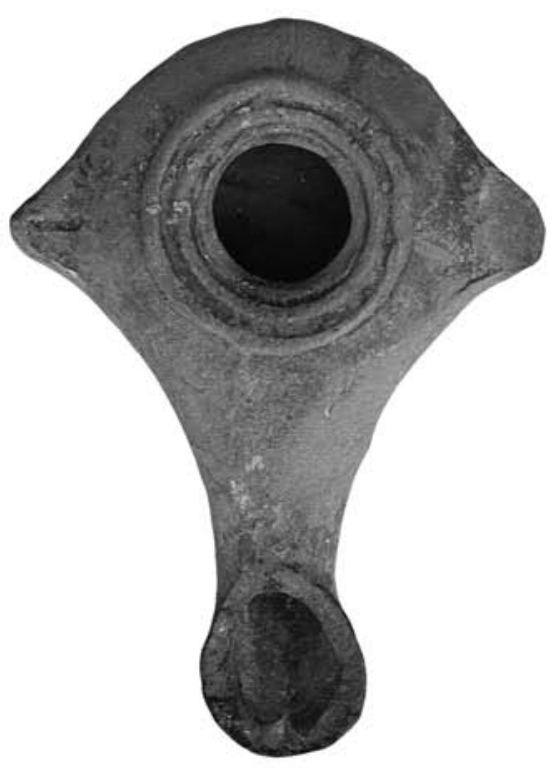

Cat.45

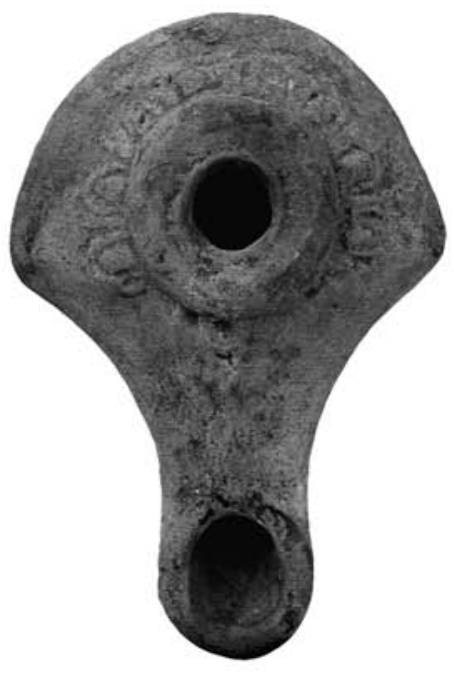

Cat.40
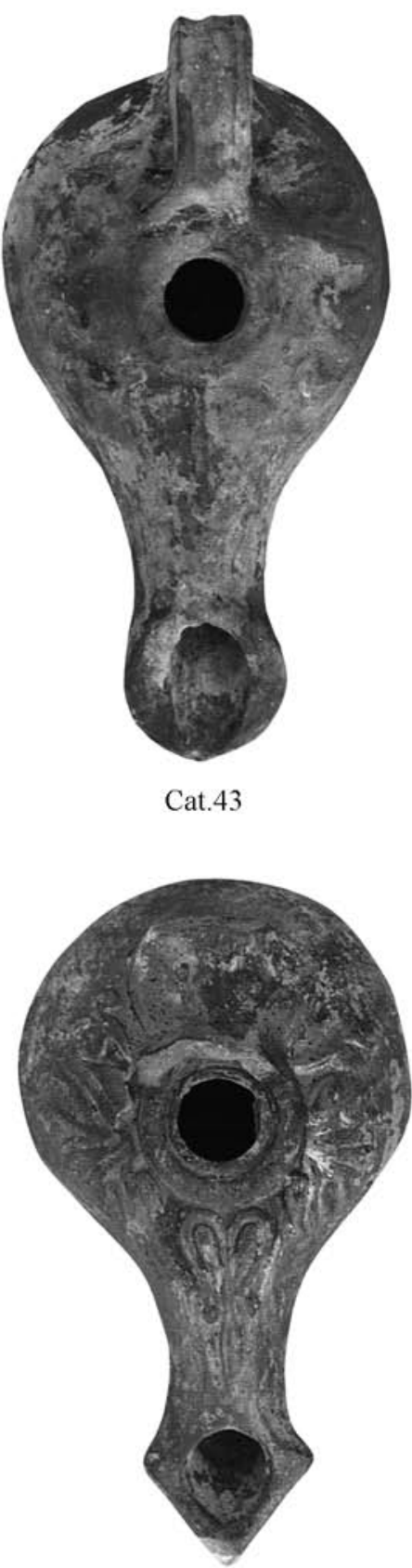

Cat.46

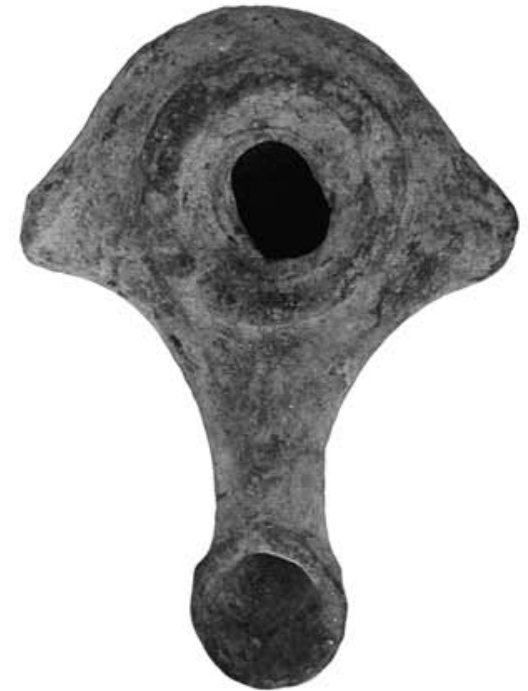

Cat.41

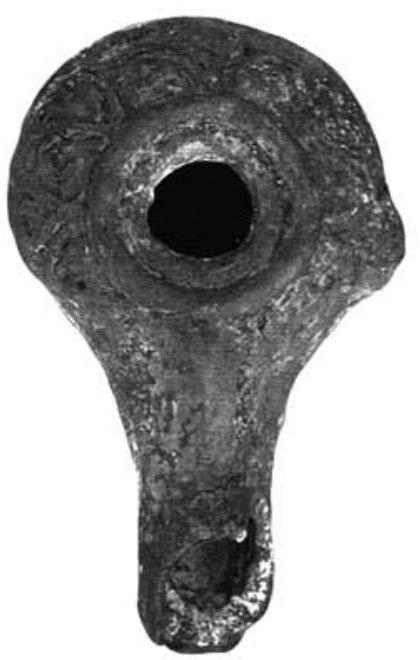

Cat.44

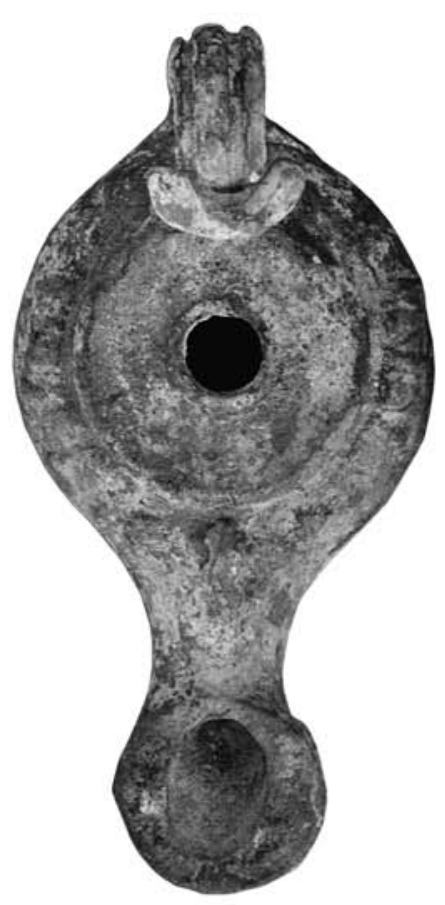

Cat.47 


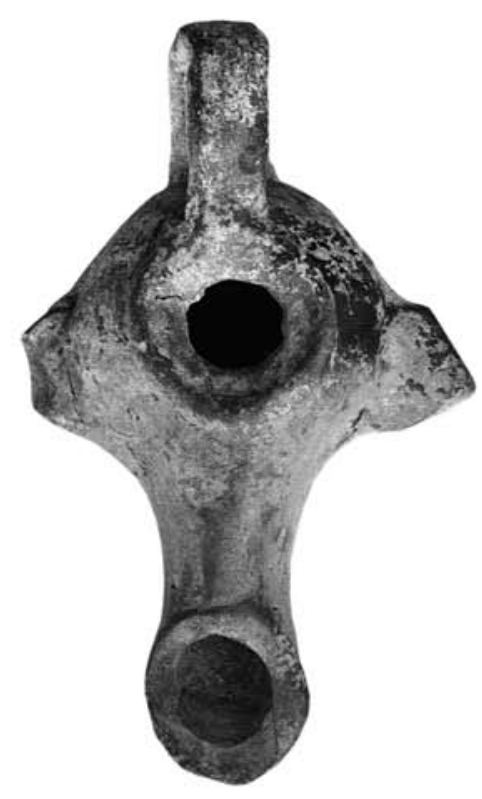

Cat.48

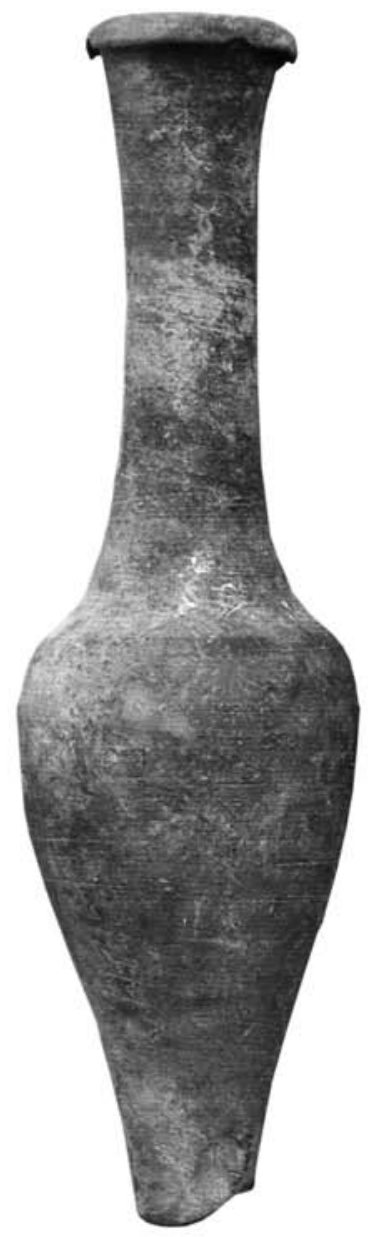

Cat. 72

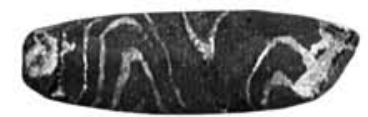

Cat. 100

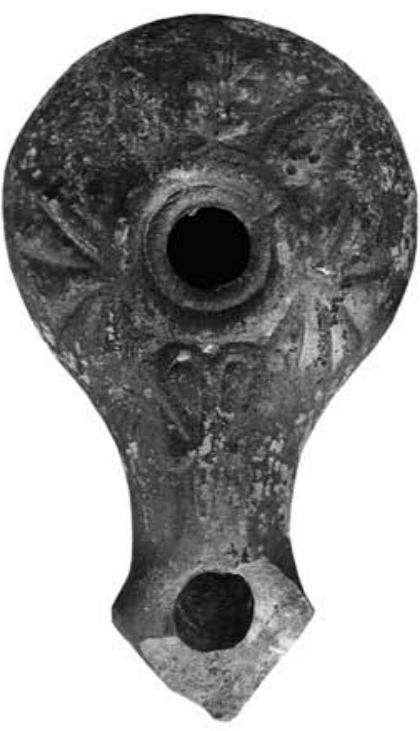

Cat.49

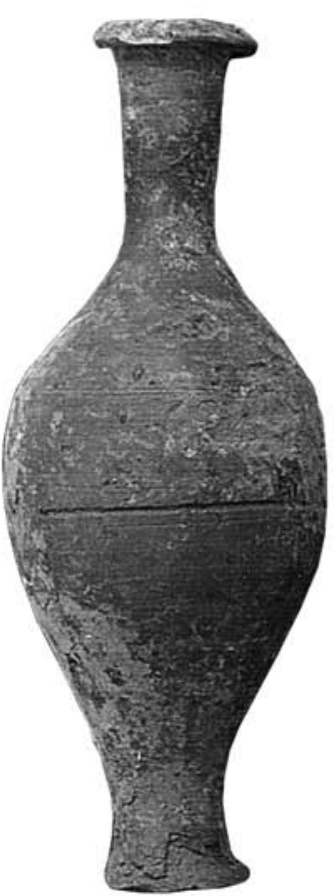

Cat. 73

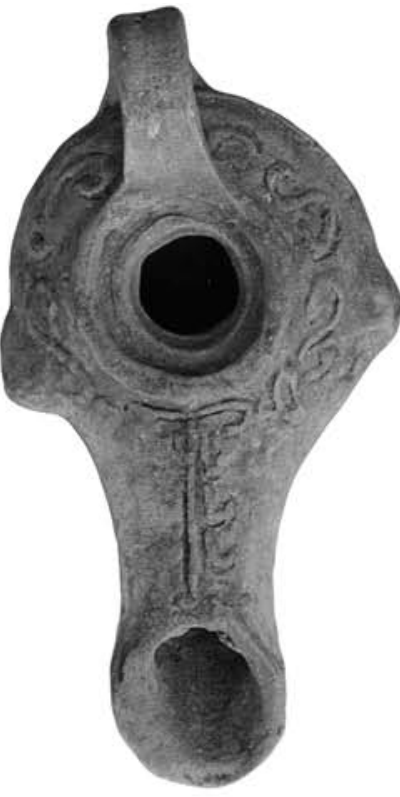

Cat.50

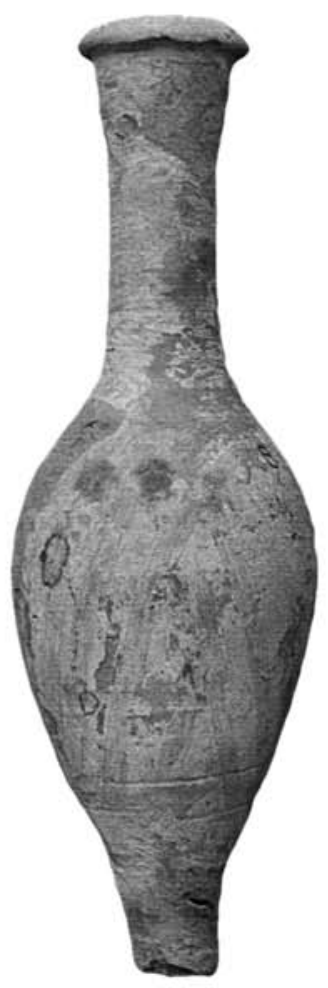

Cat.74

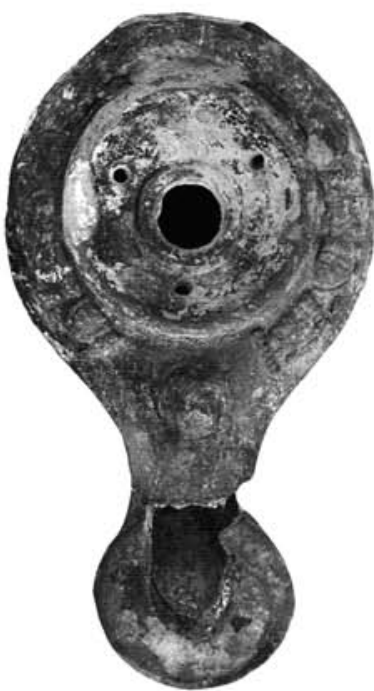

Cat.62

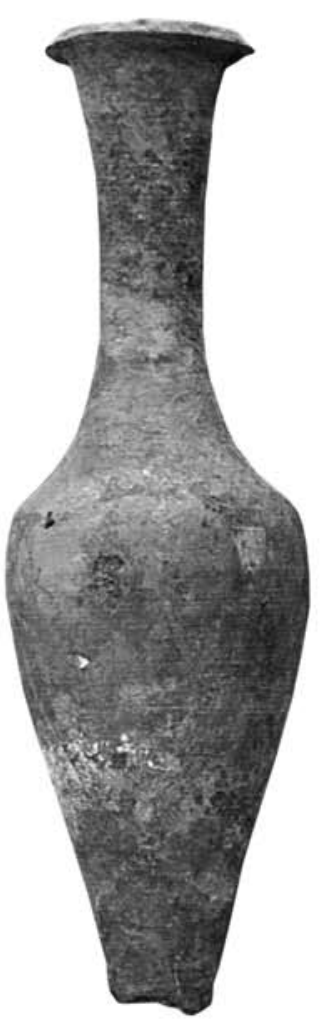

Cat. 75 

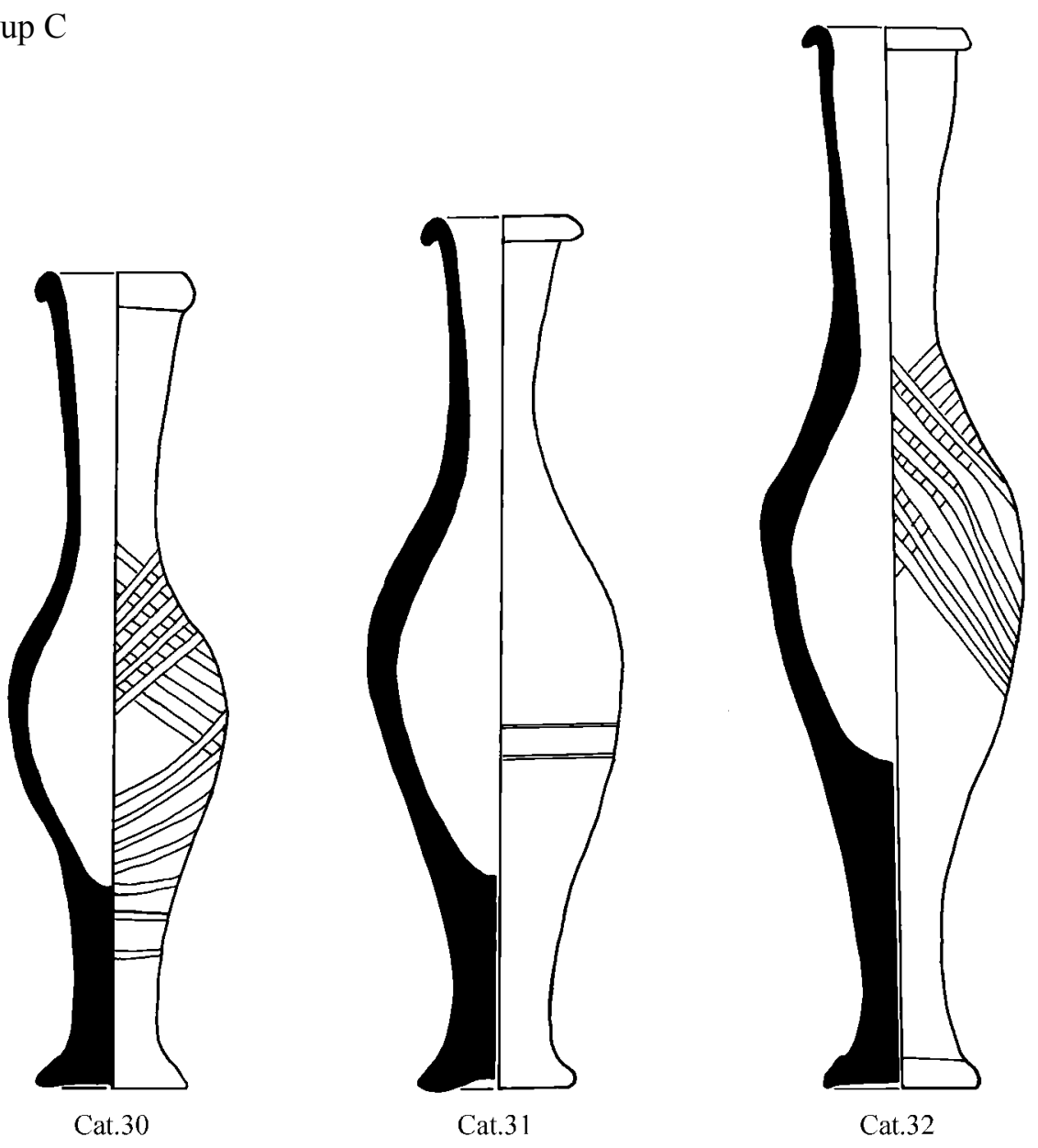

Plate 21
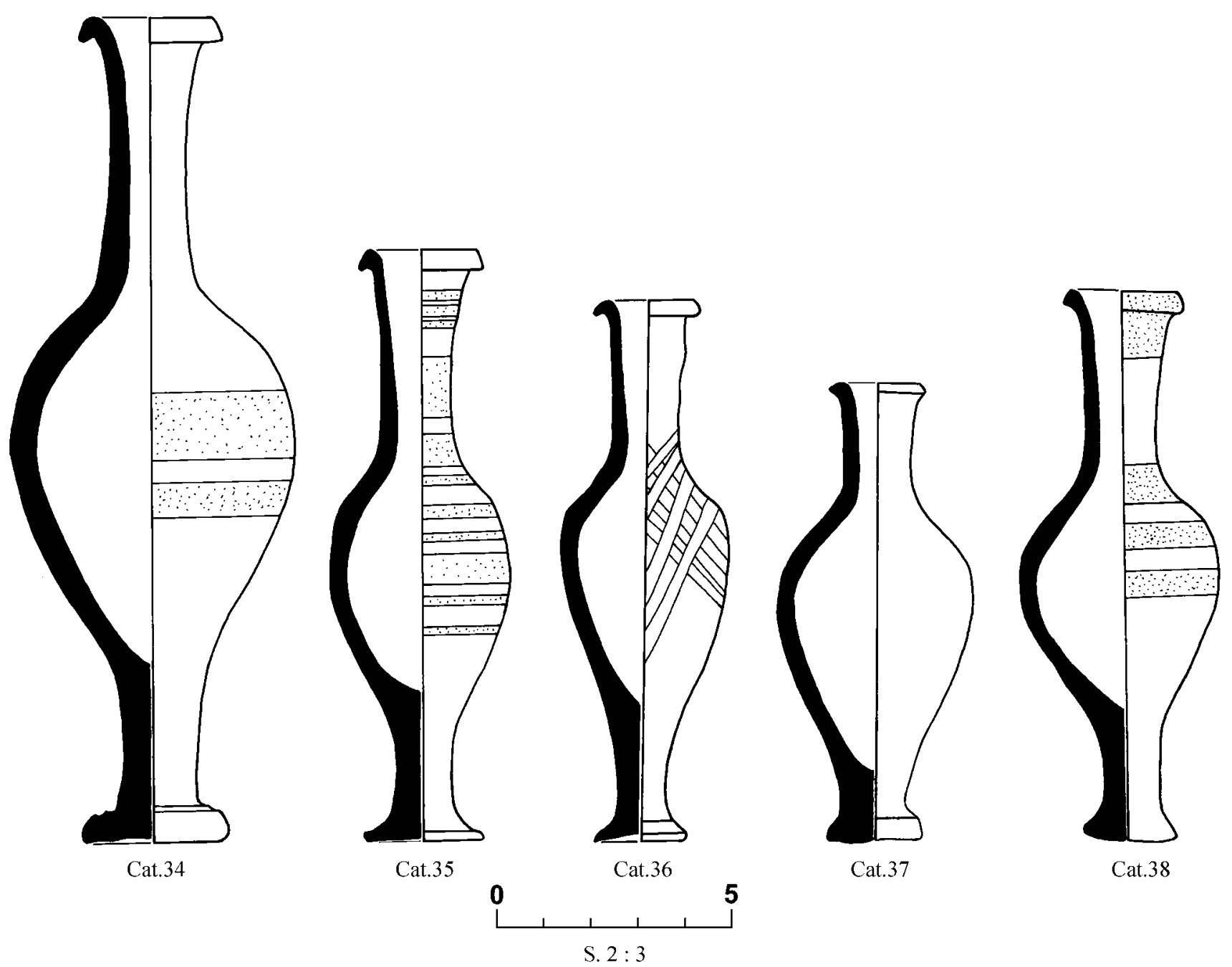

Cat.34
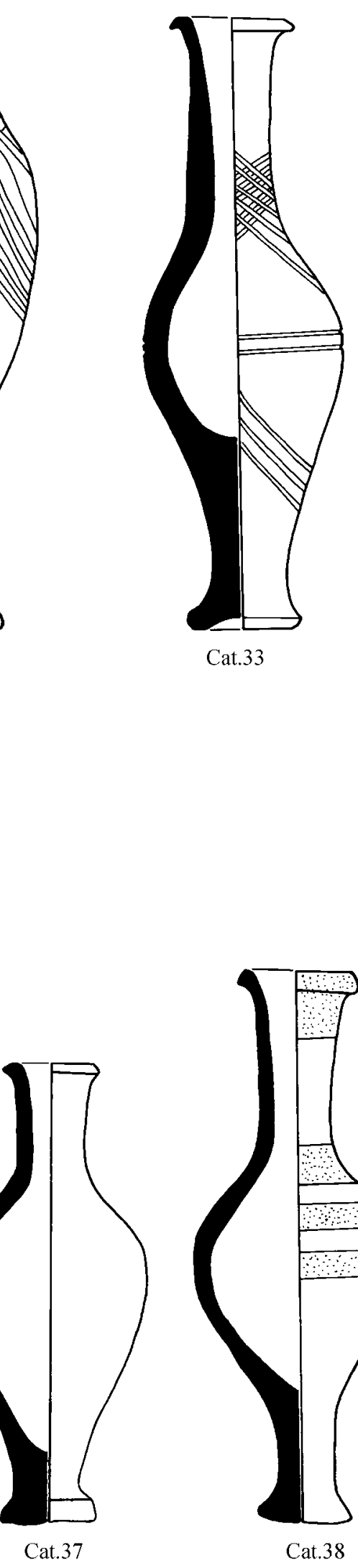

Cat.33 


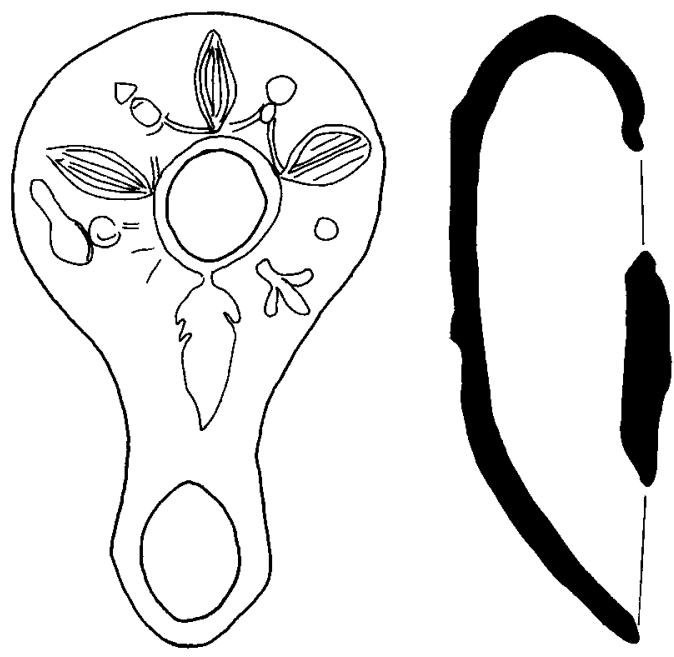

Cat.39

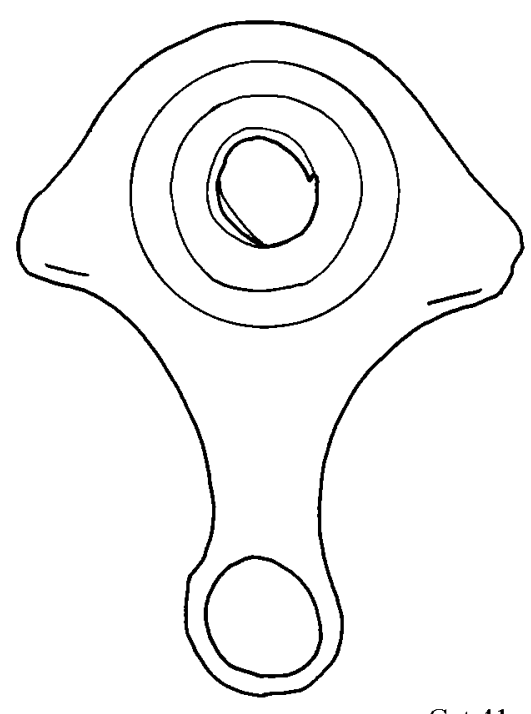

Cat.41
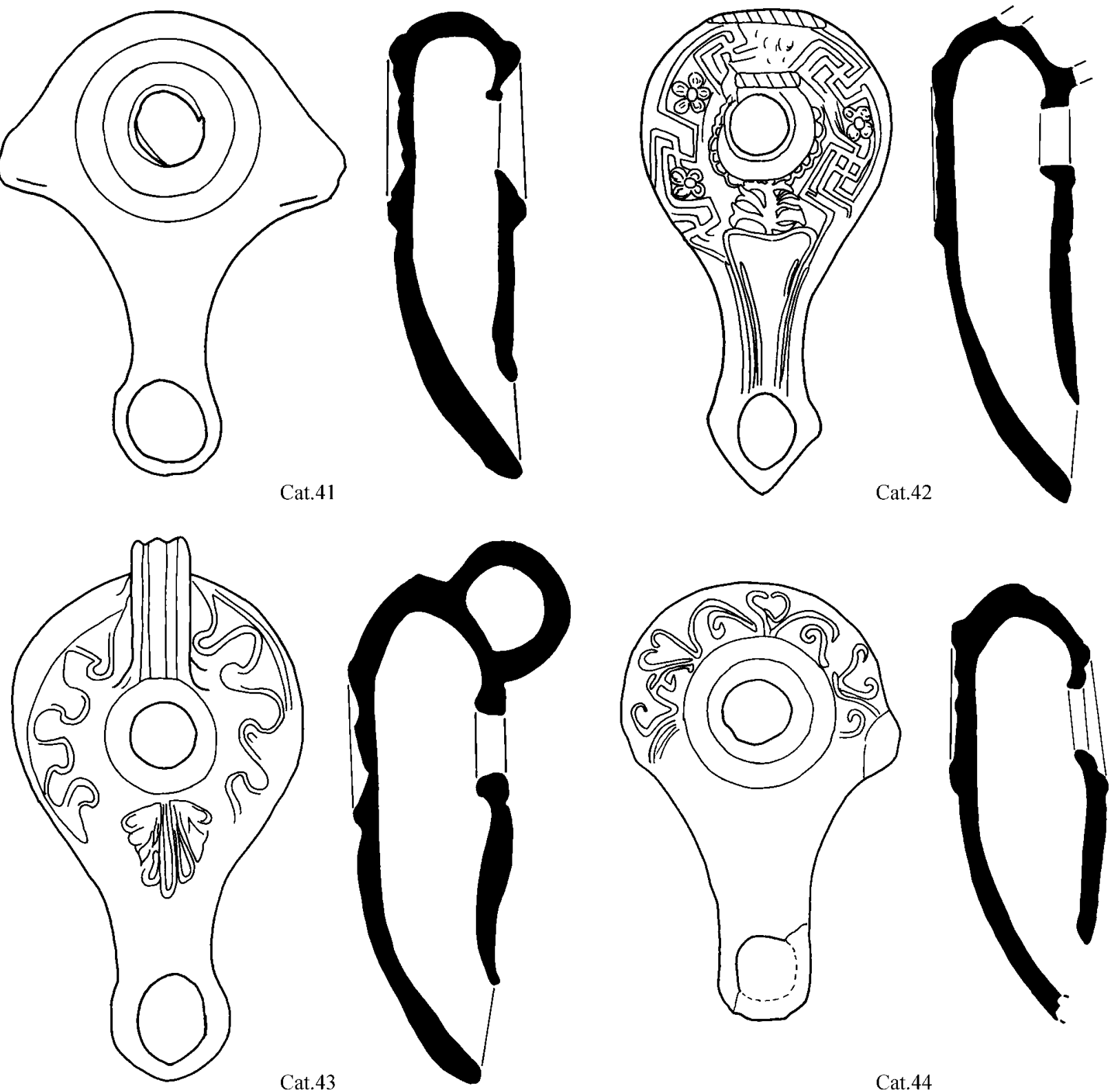

Cat.44

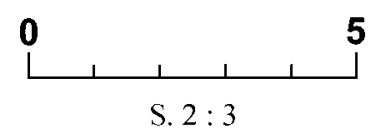


Group C
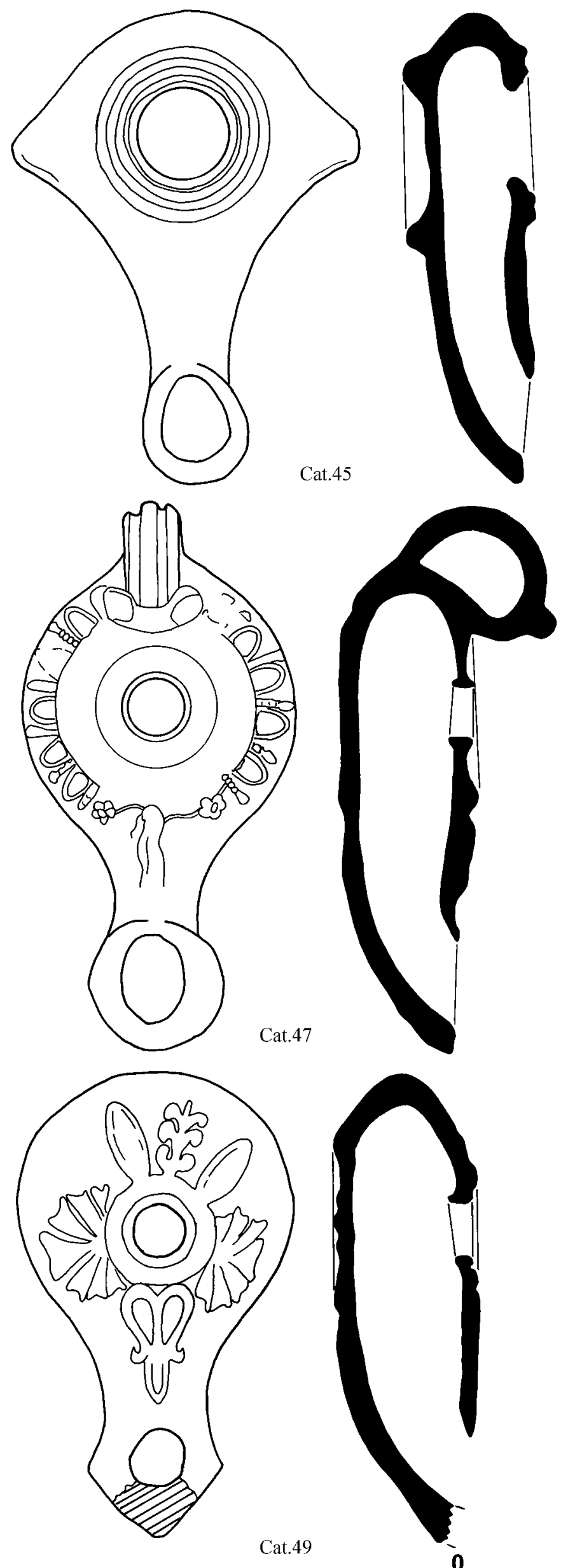

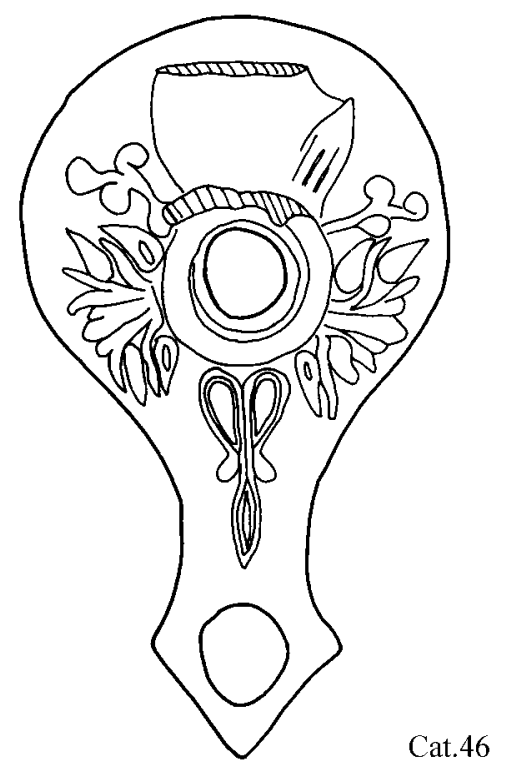

Plate 23
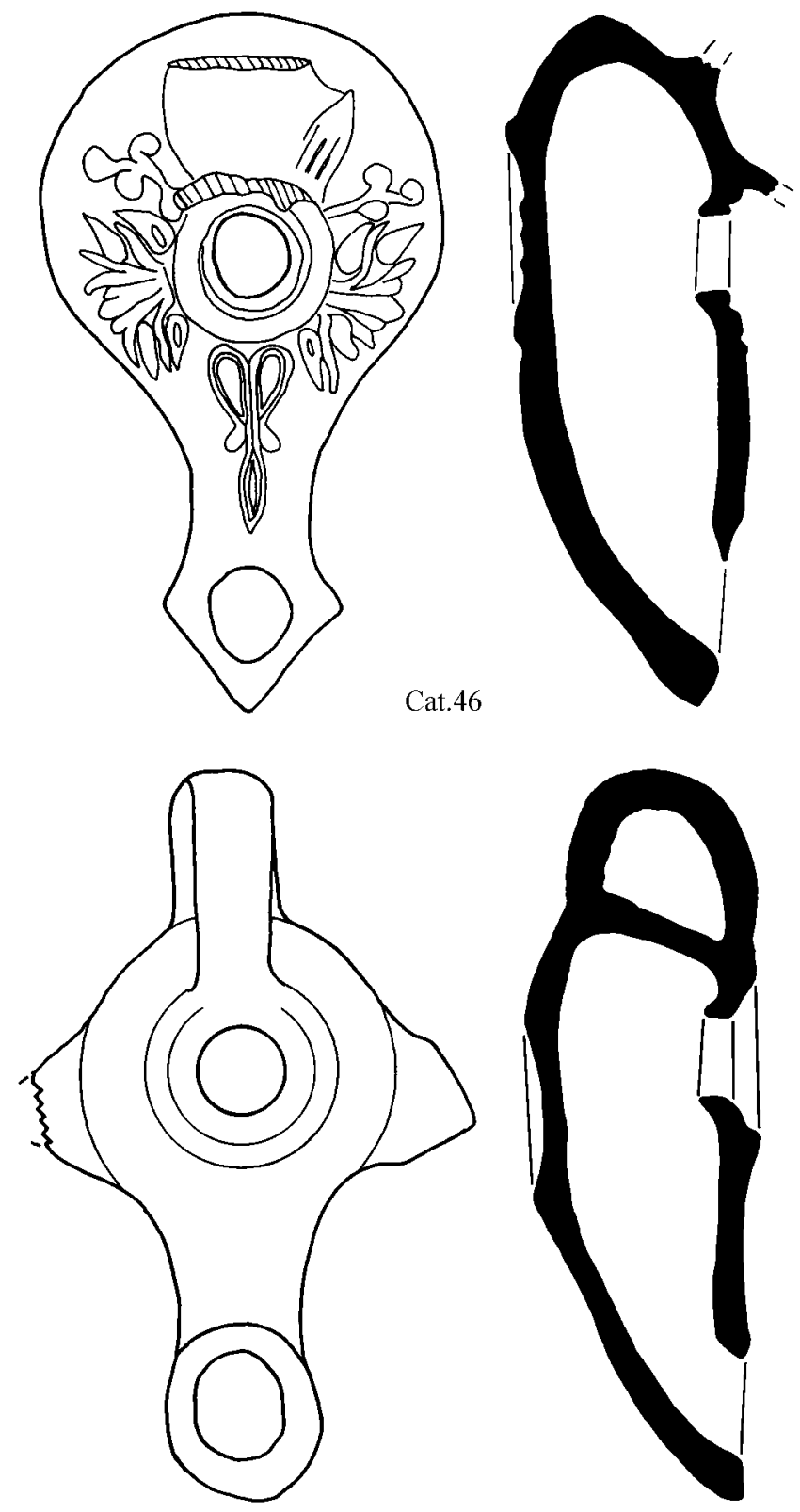

Cat.48

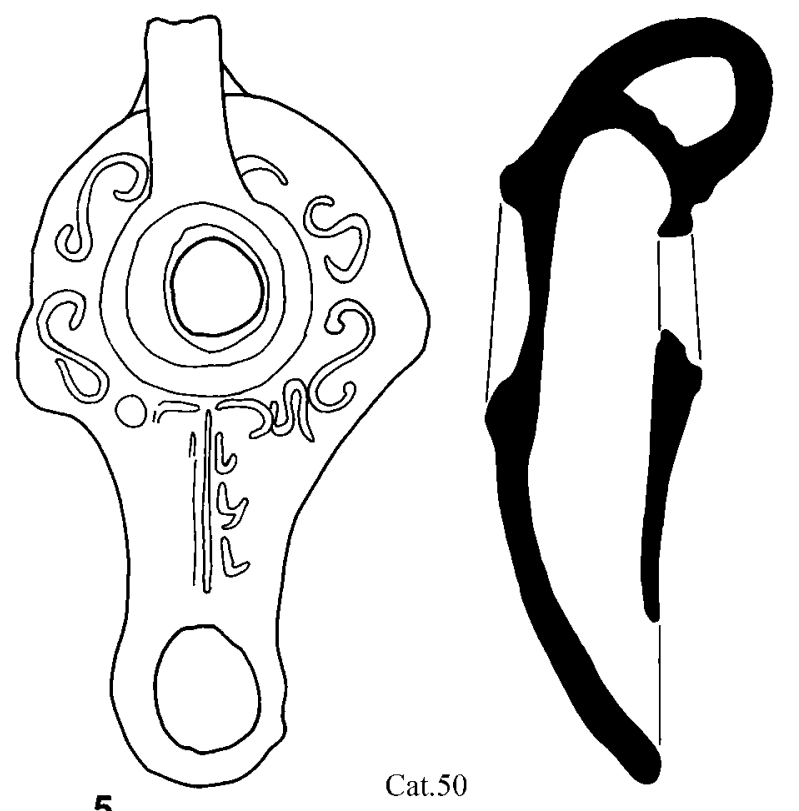




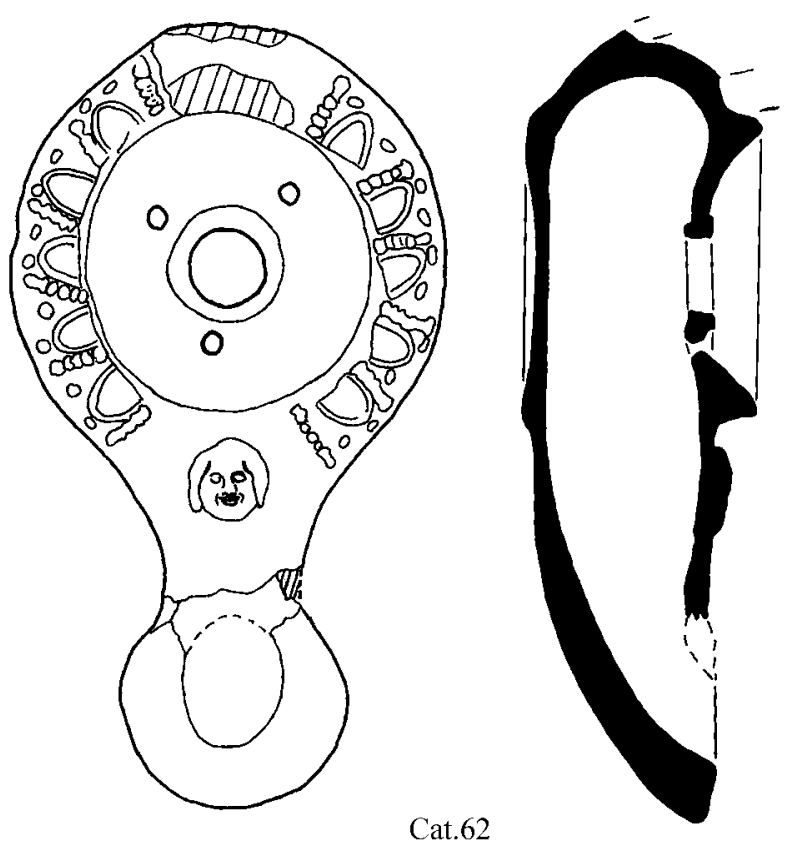

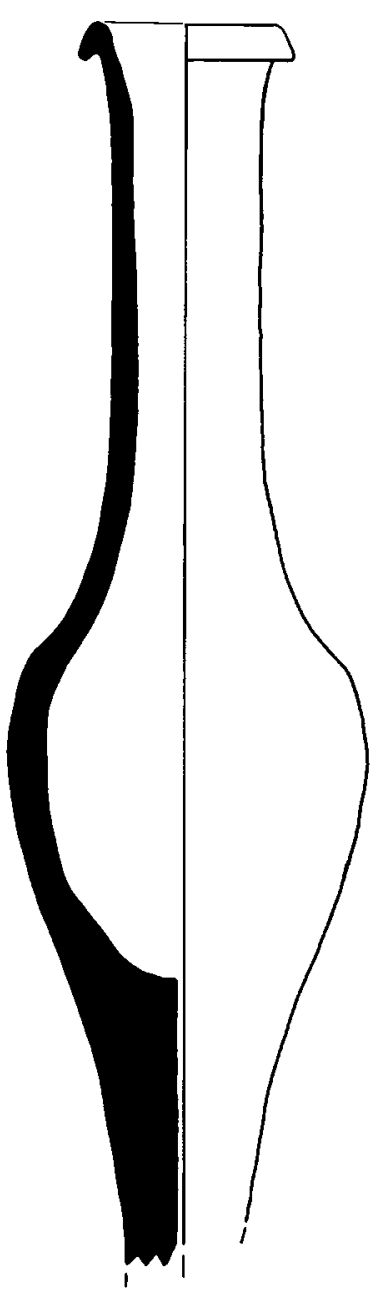

Cat. 72

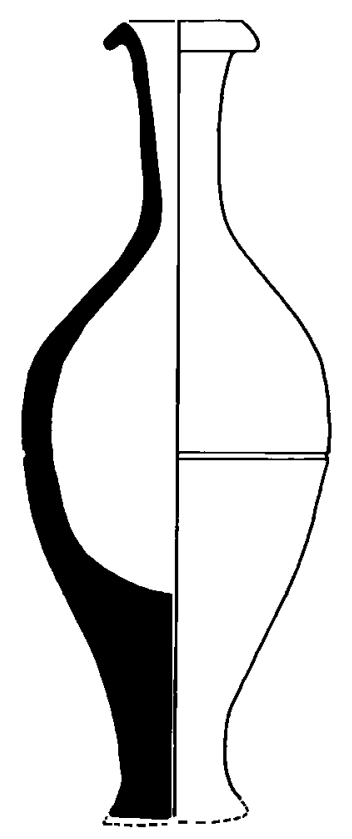

Cat. 73

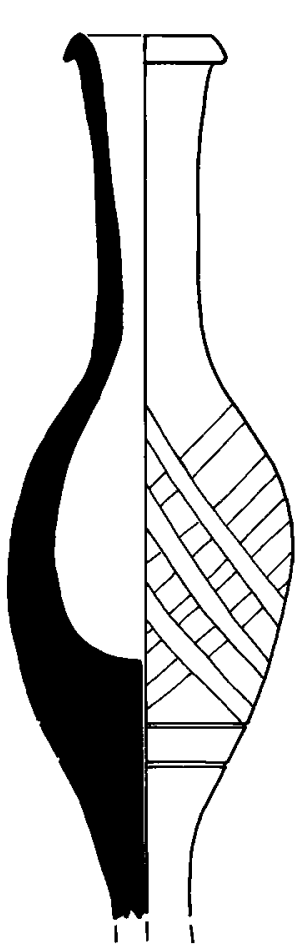

Cat. 74

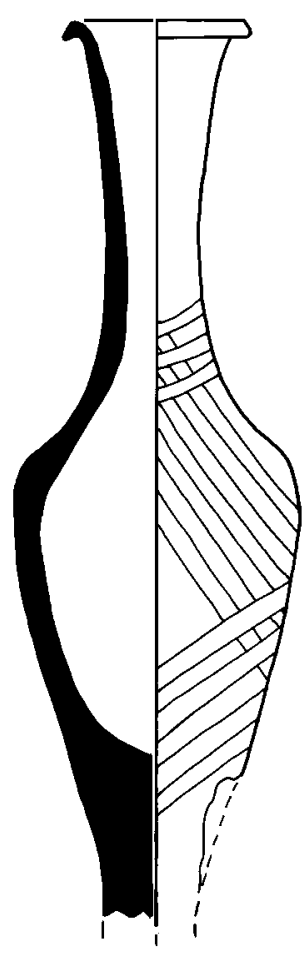

Cat. 75

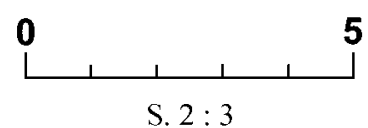


Group D
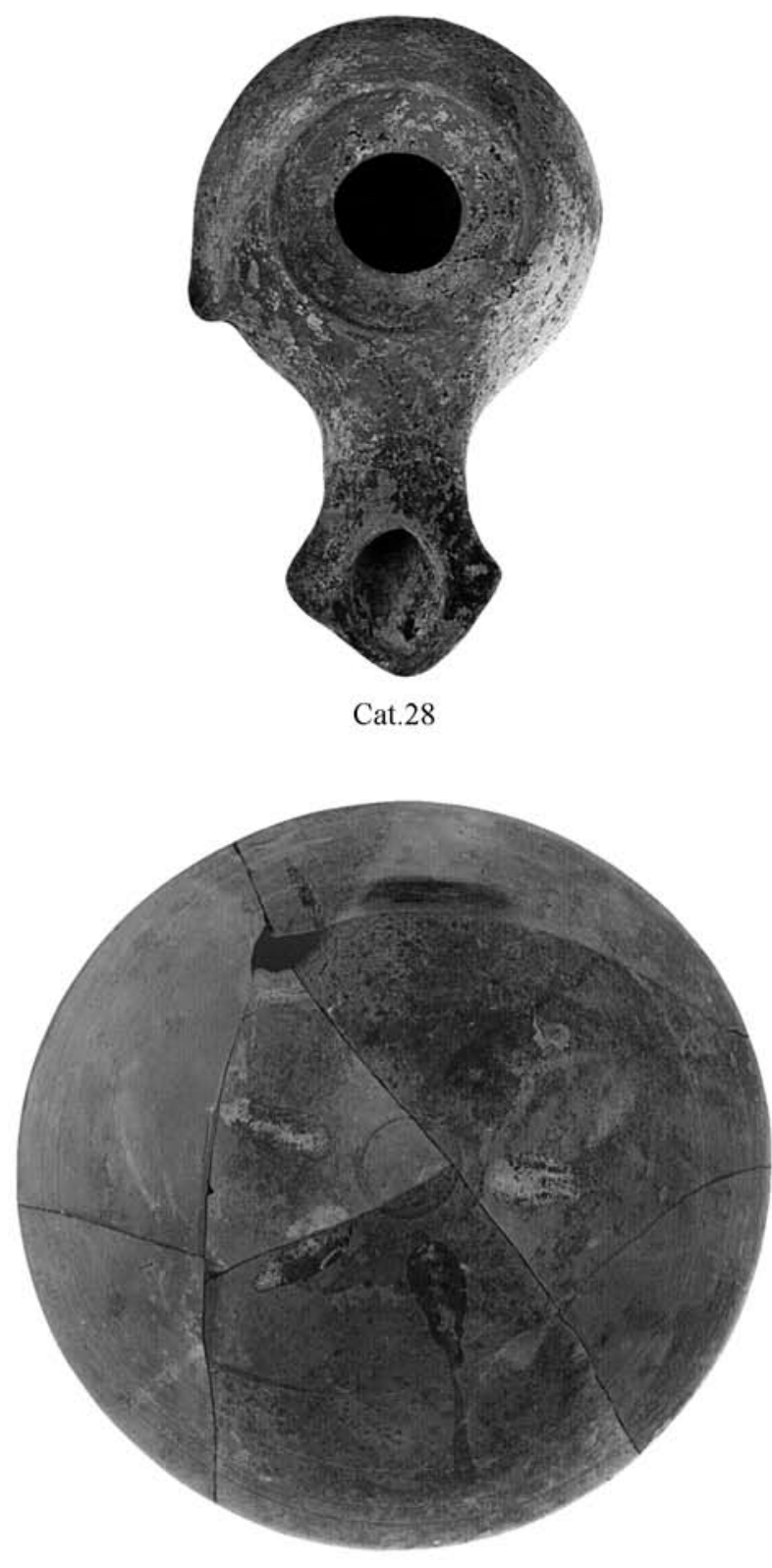

Cat.53

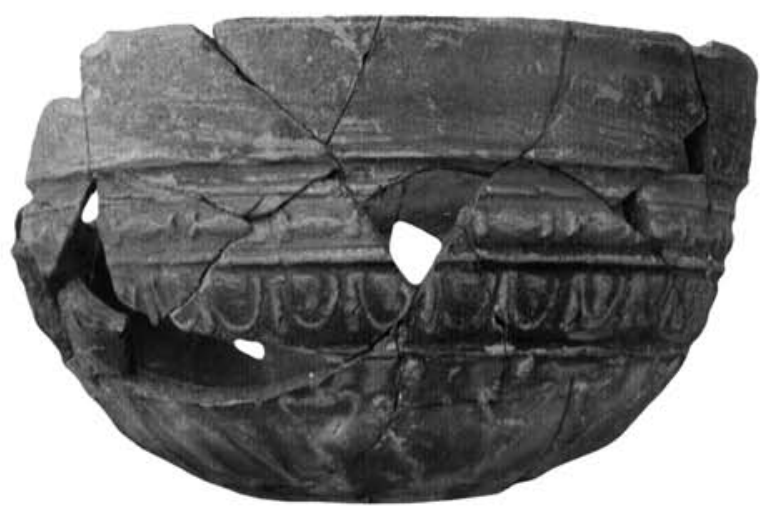

Cat.55
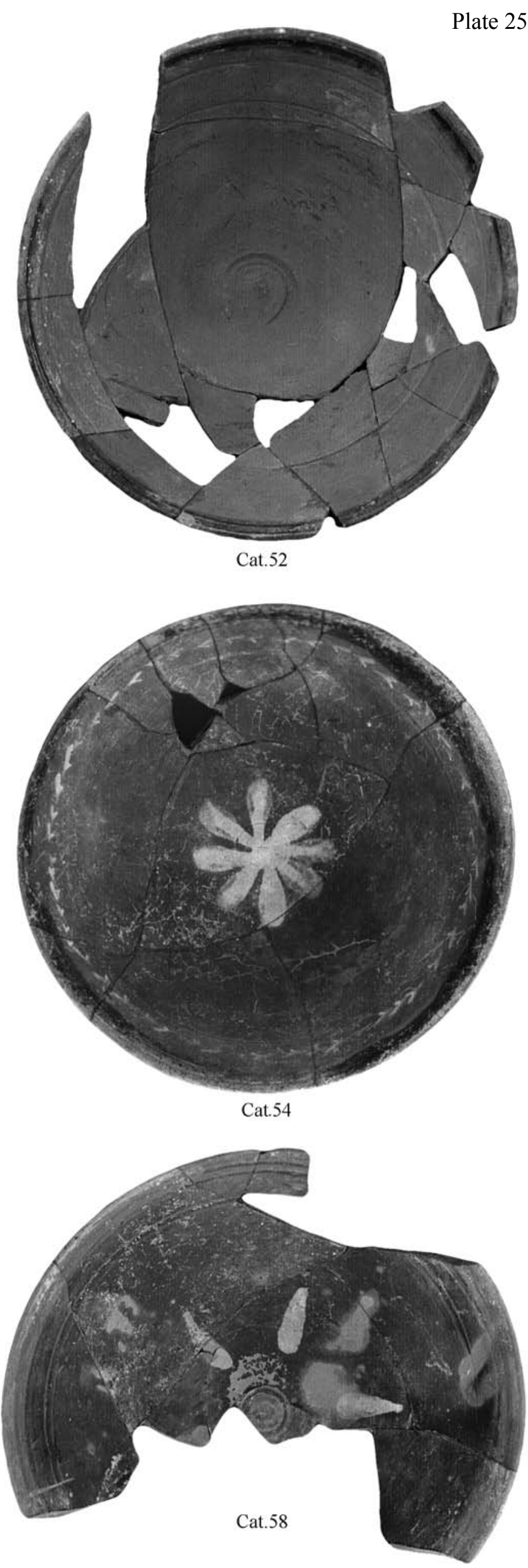

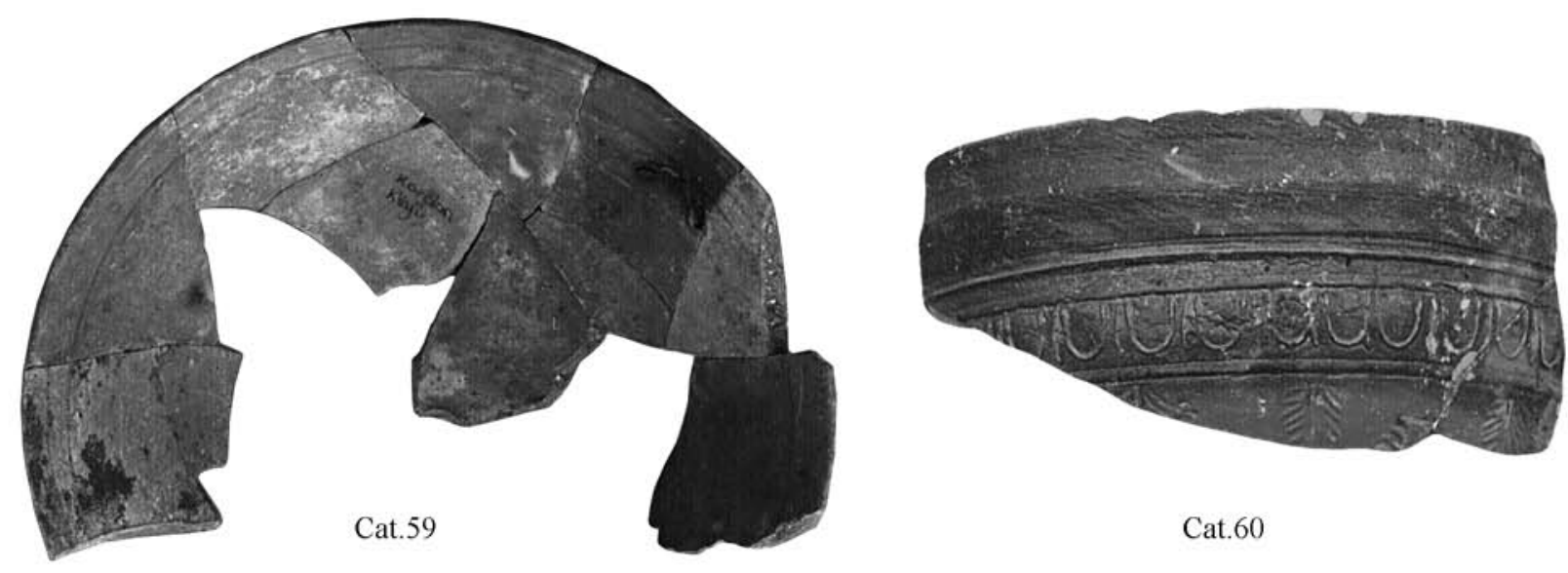

Cat.60
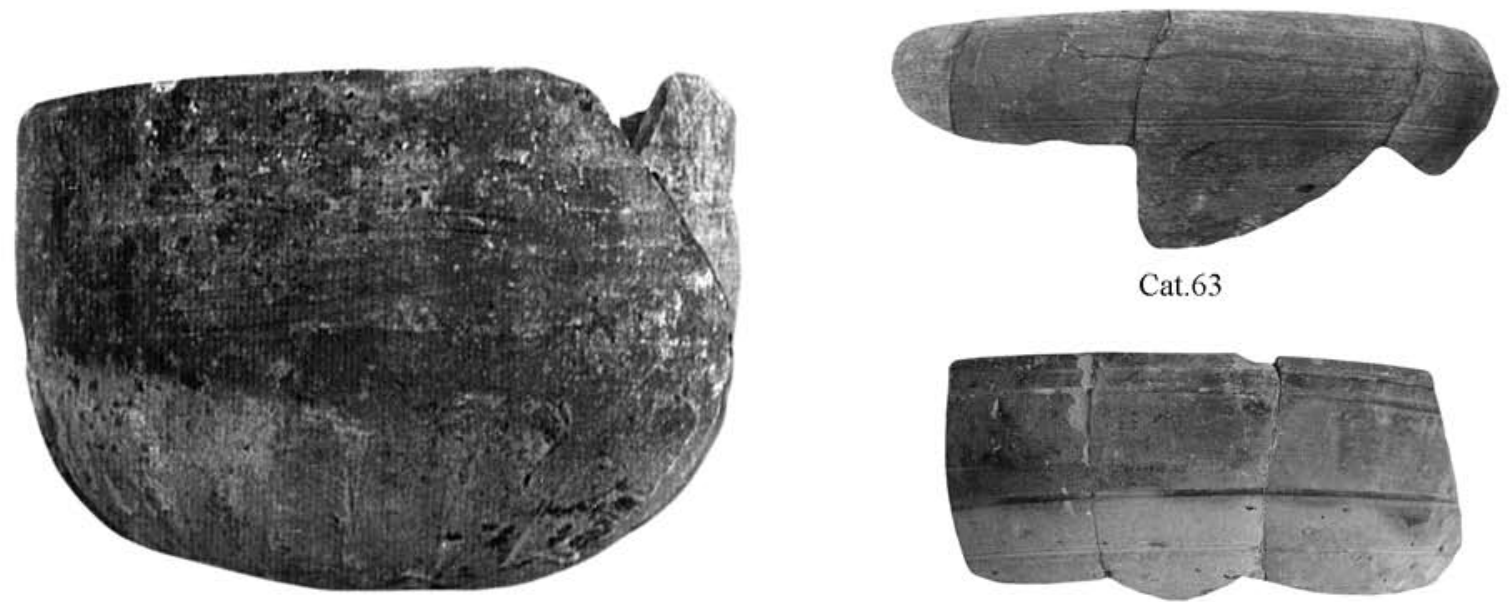

Cat.63

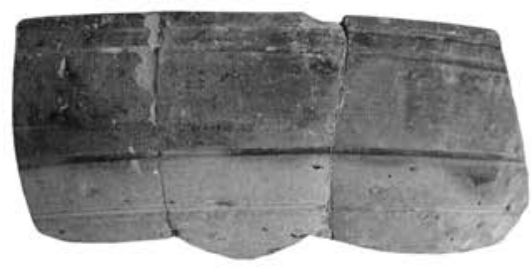

Cat.61

Cat.64
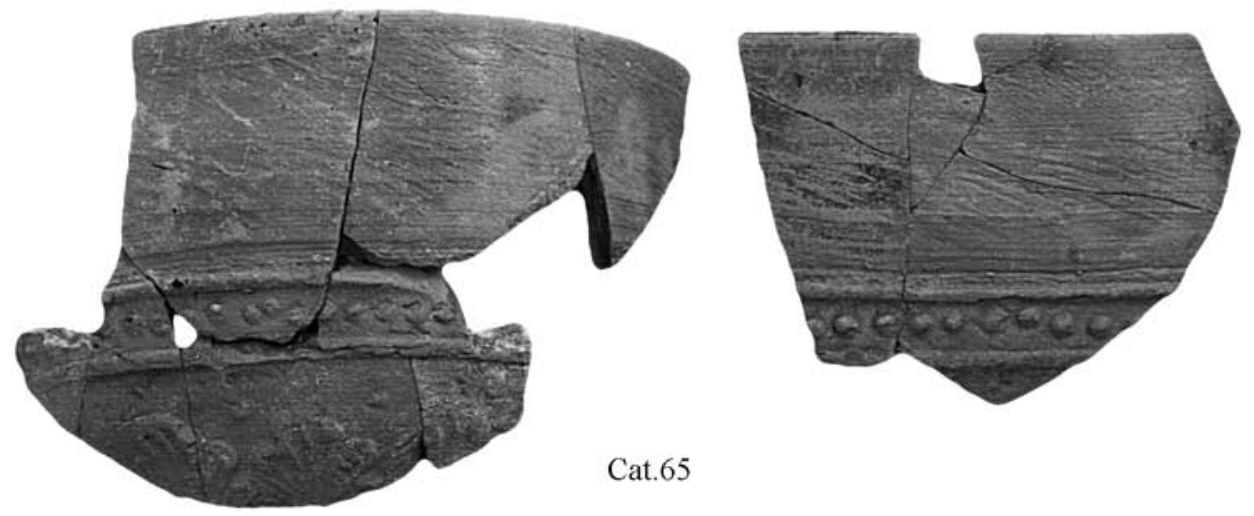

Cat.65

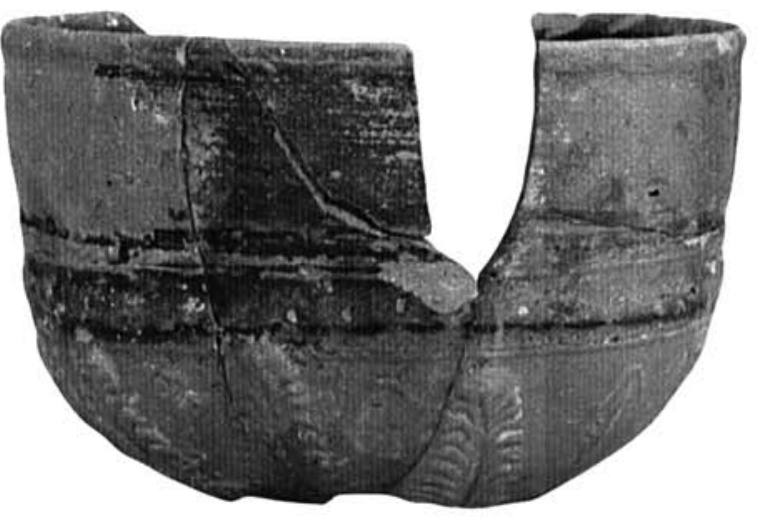

Cat.66 

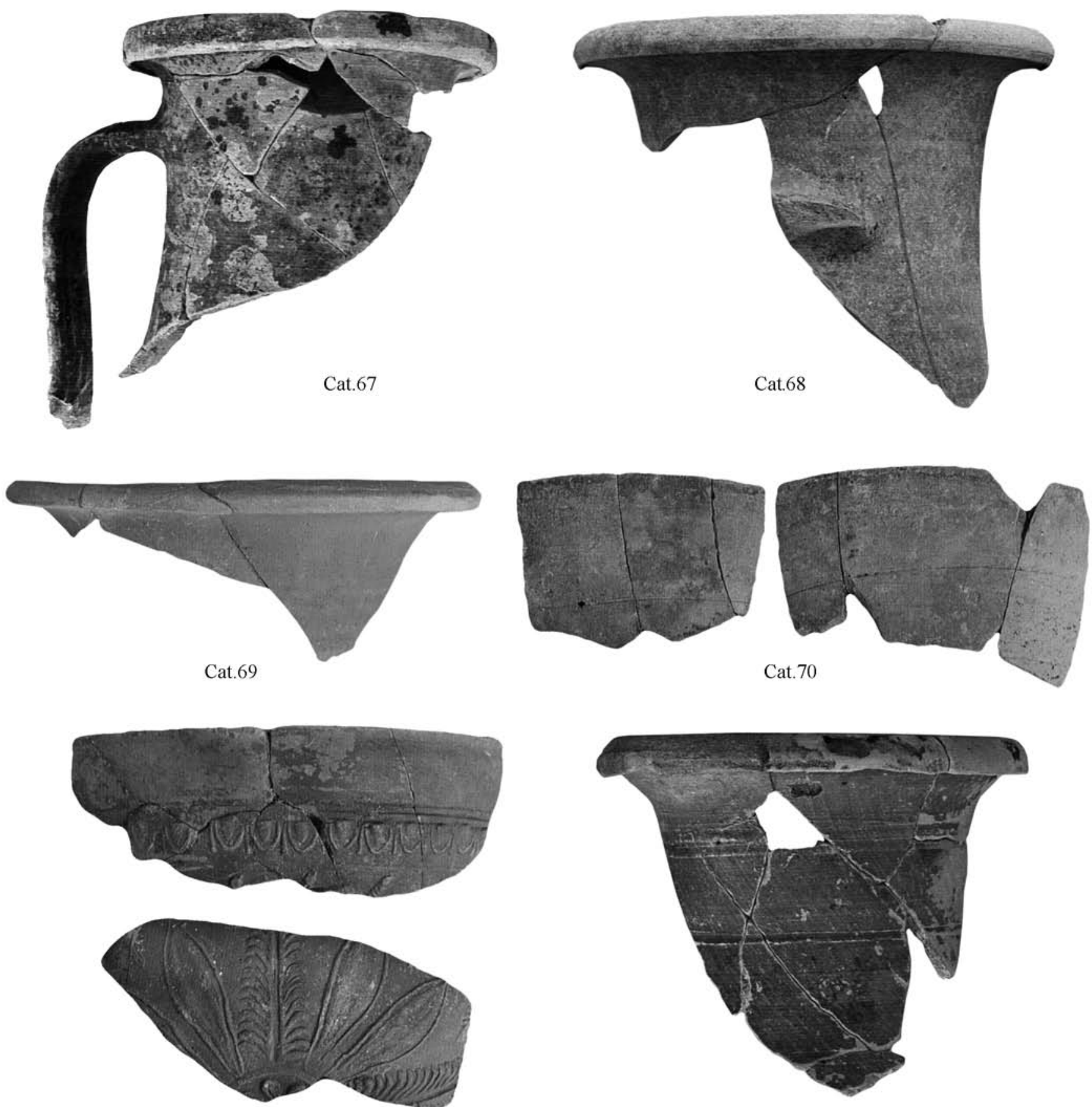

Cat.71

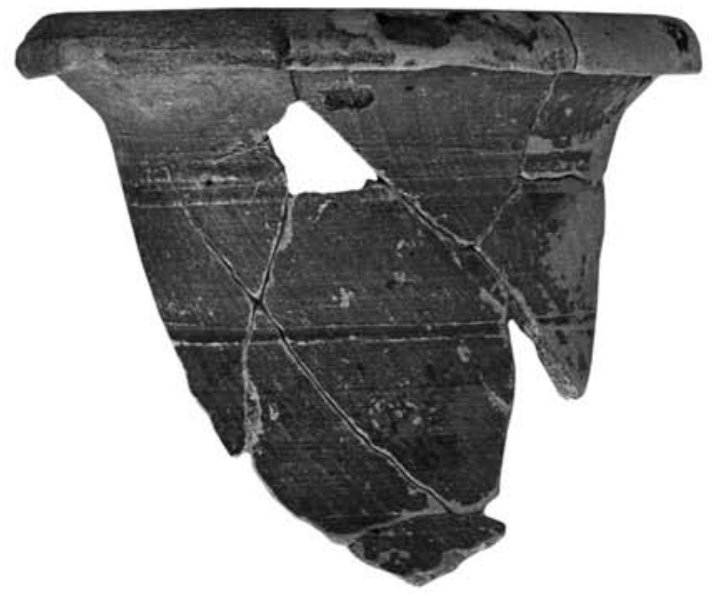

Cat. 78

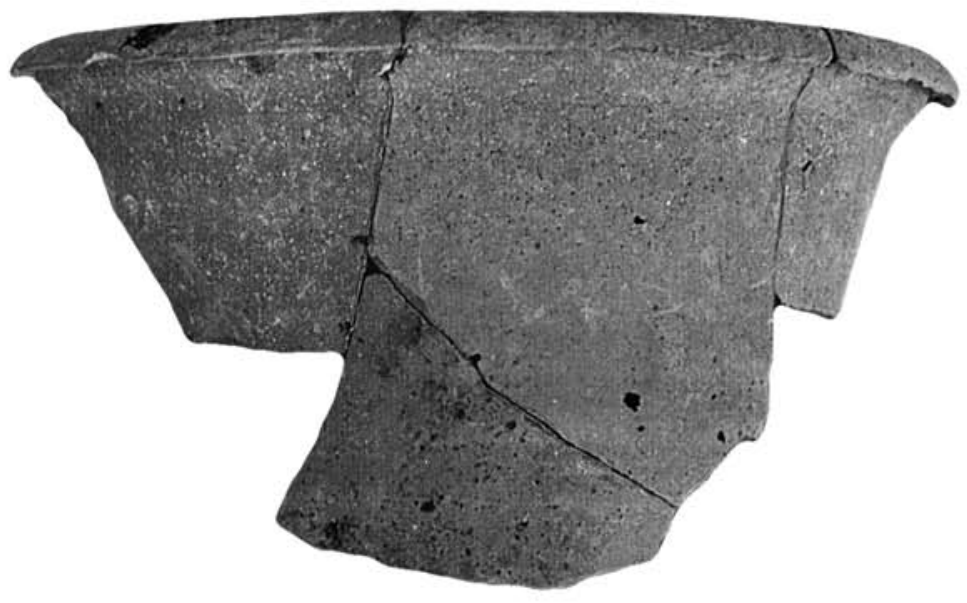

Cat.80
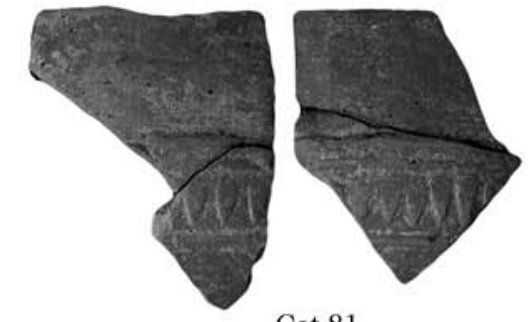

Cat.81
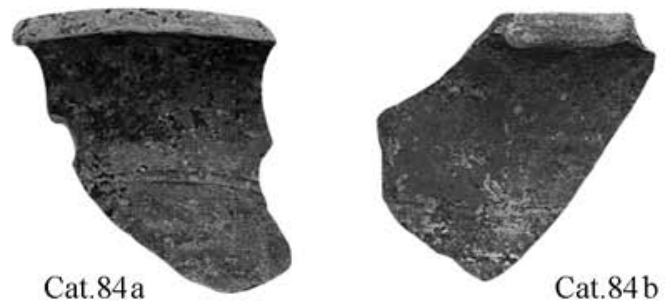


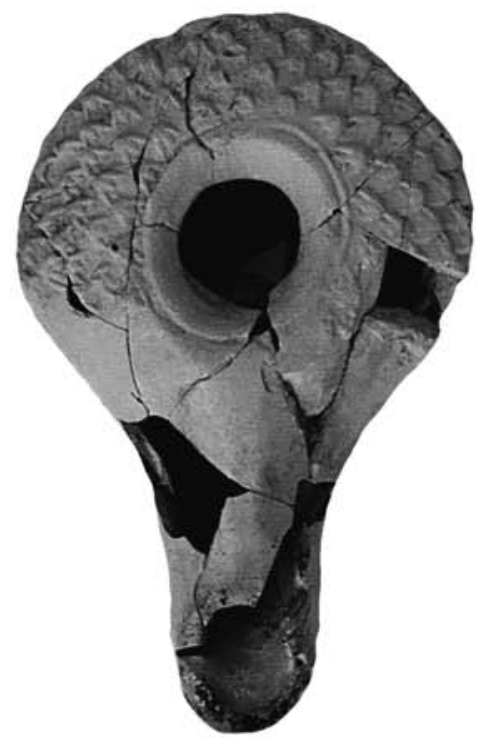

Cat.86
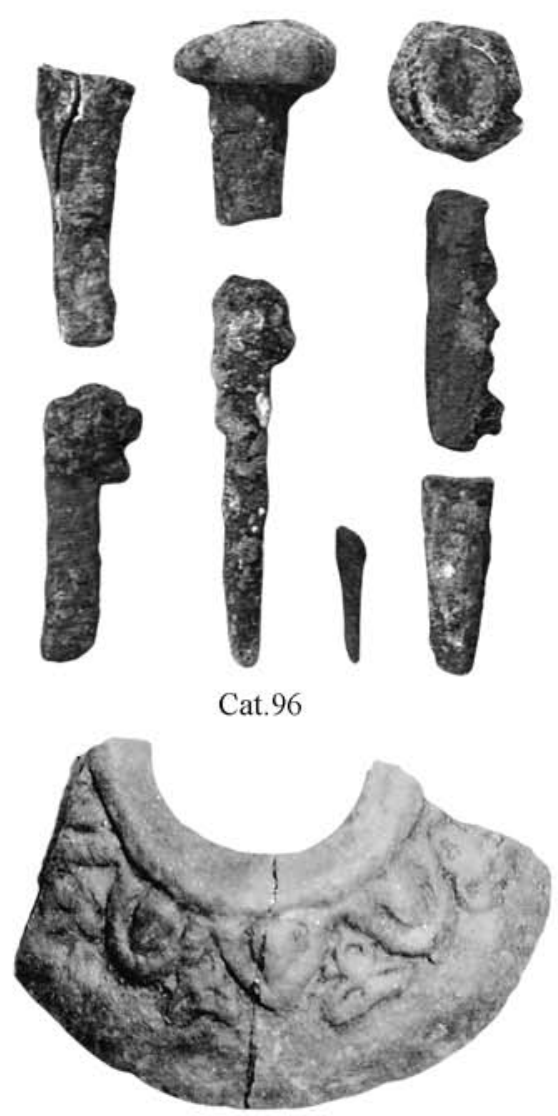

Cat. 103

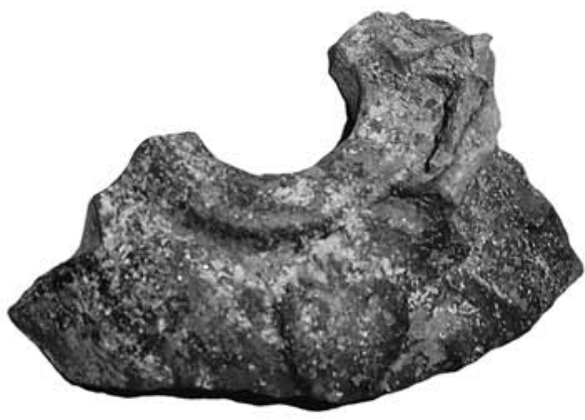

Cat.105

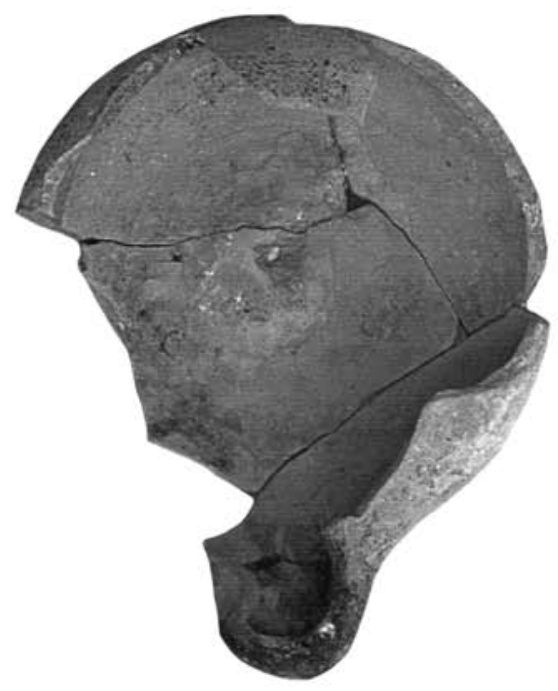

Cat.87

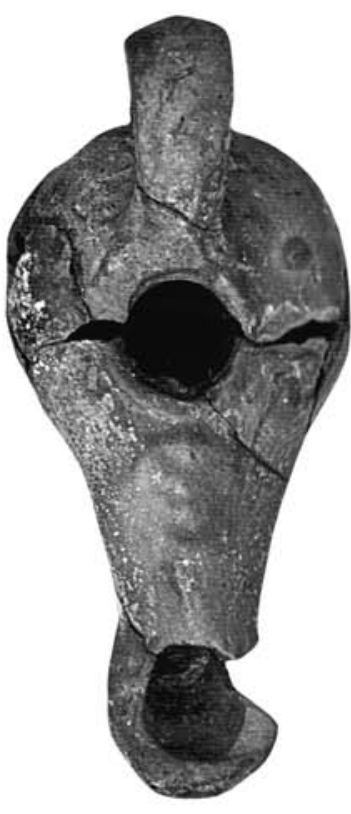

Cat.88

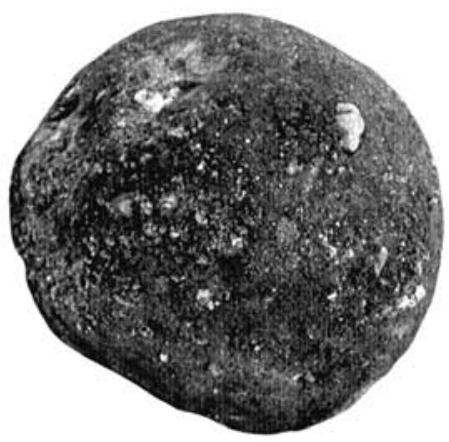

Cat.102

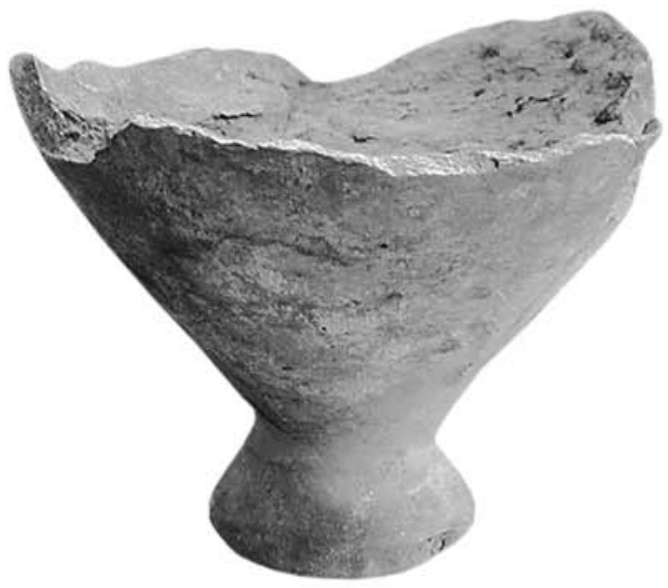

Cat. 104 

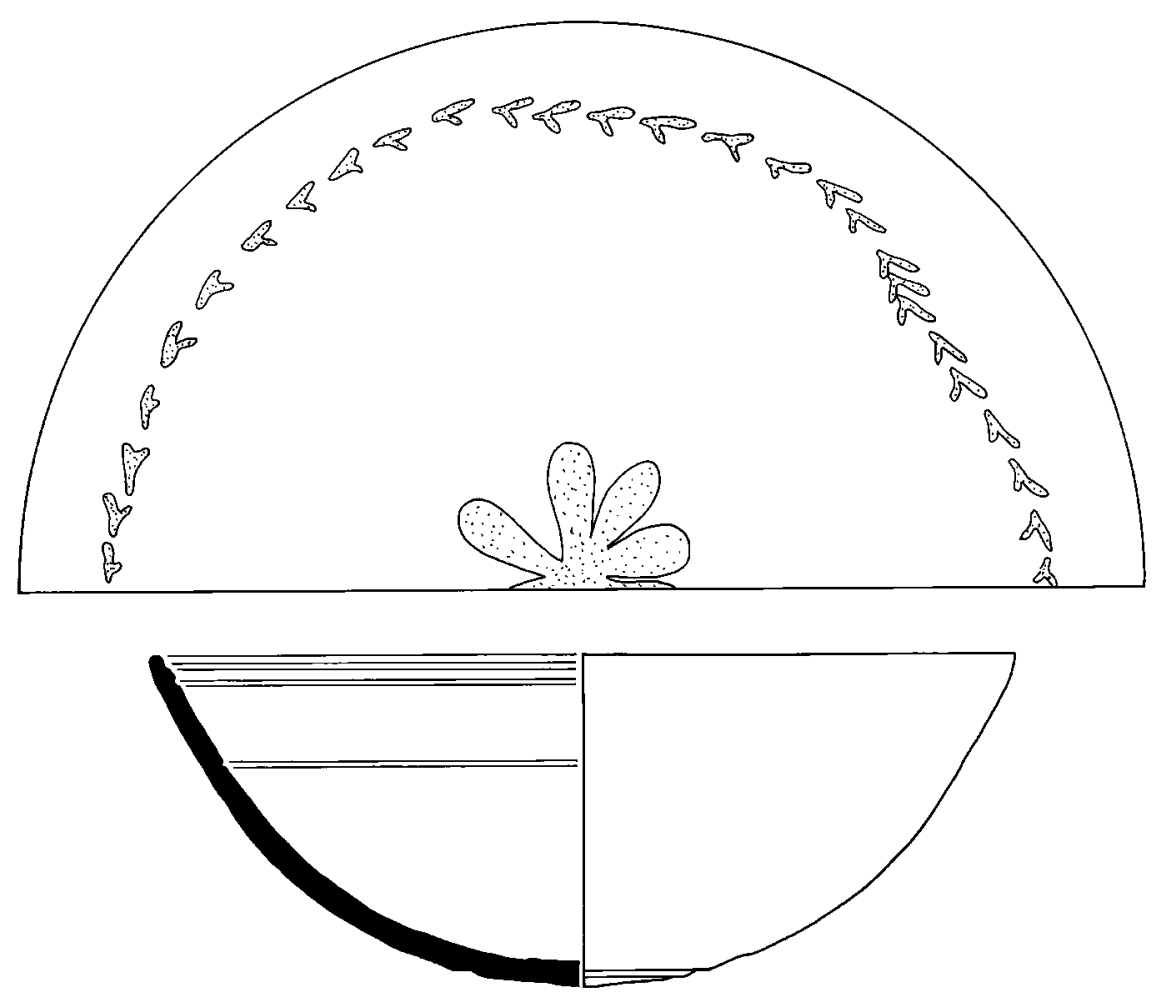

Cat.54
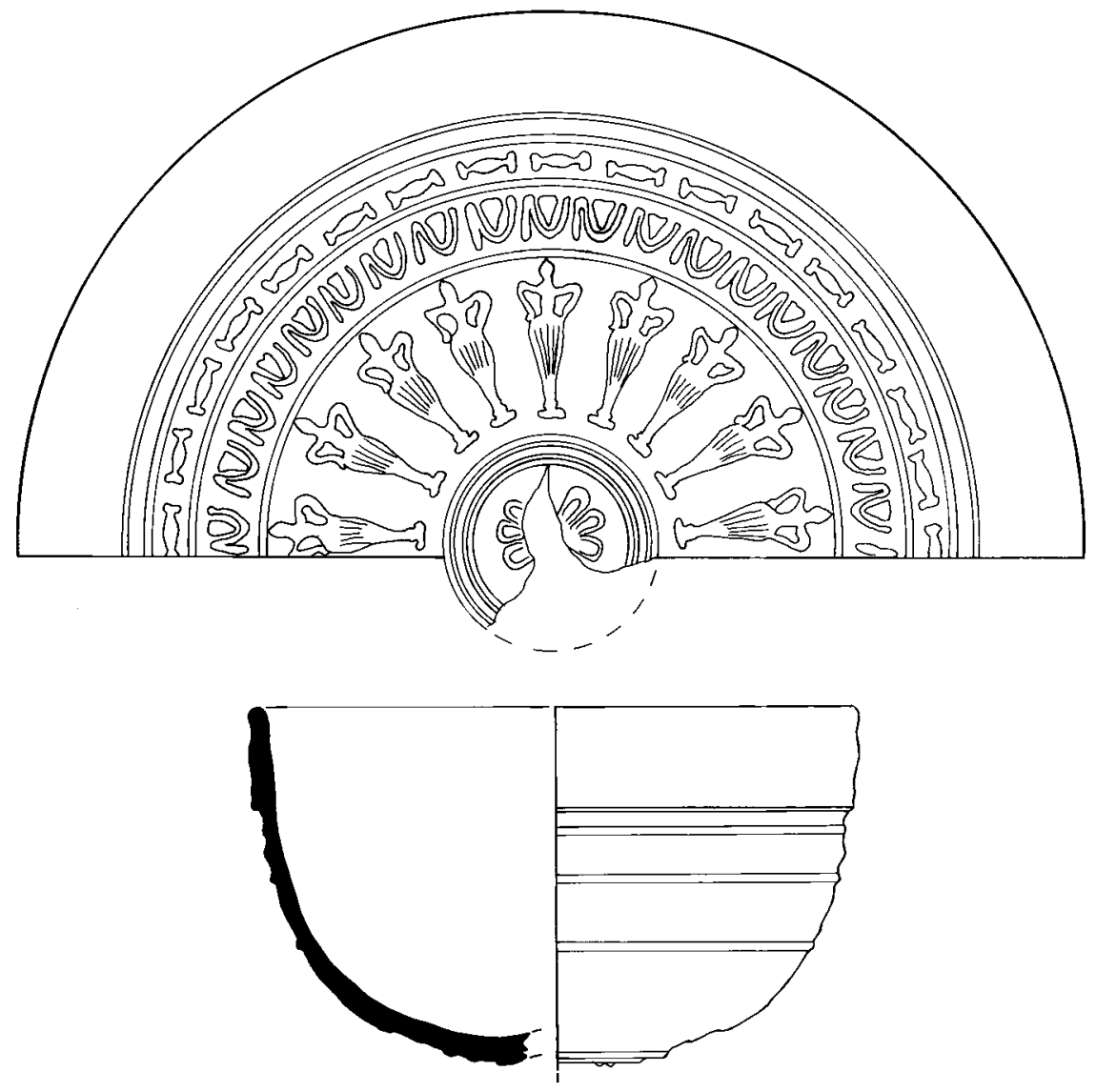

Cat.55

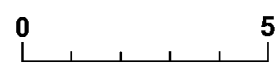

S. $1: 2$ 
Plate 30

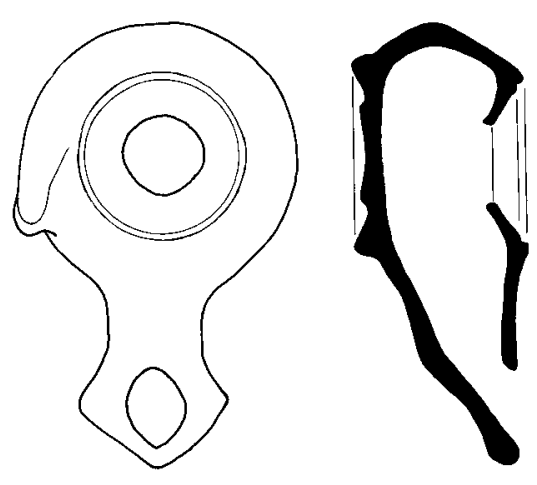

Cat.28

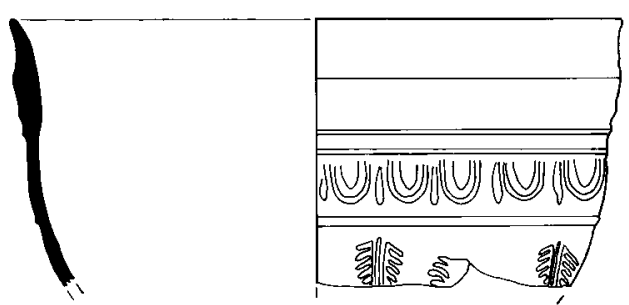

Cat.60
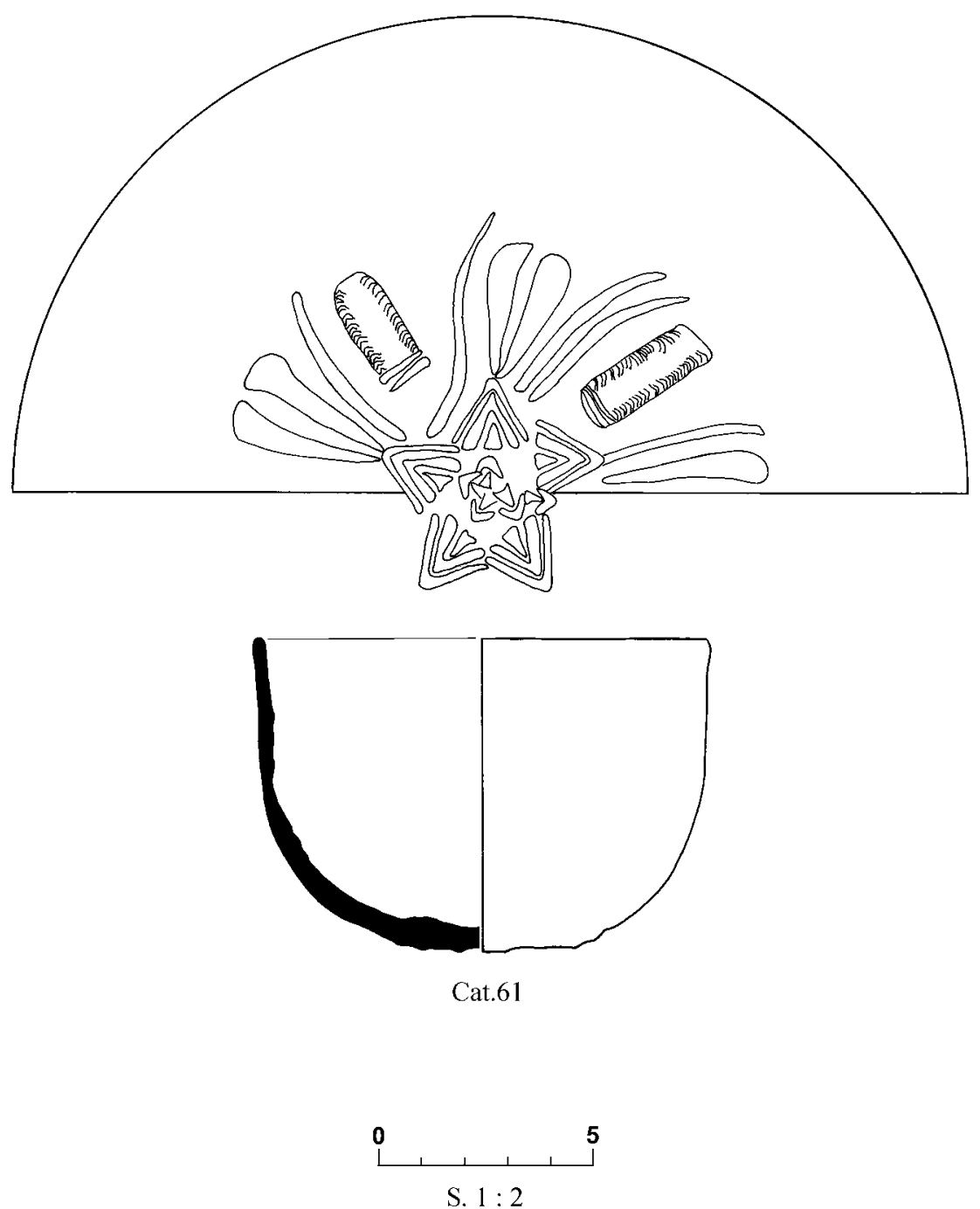


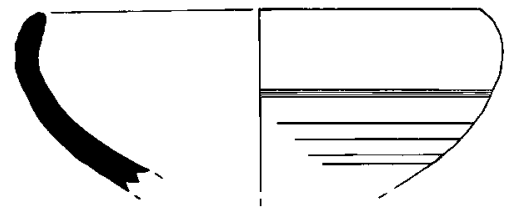

Cat.63

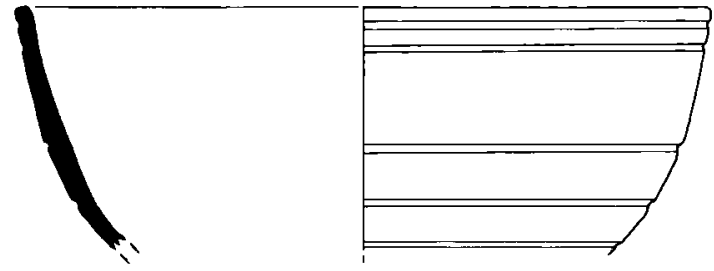

Cat.64

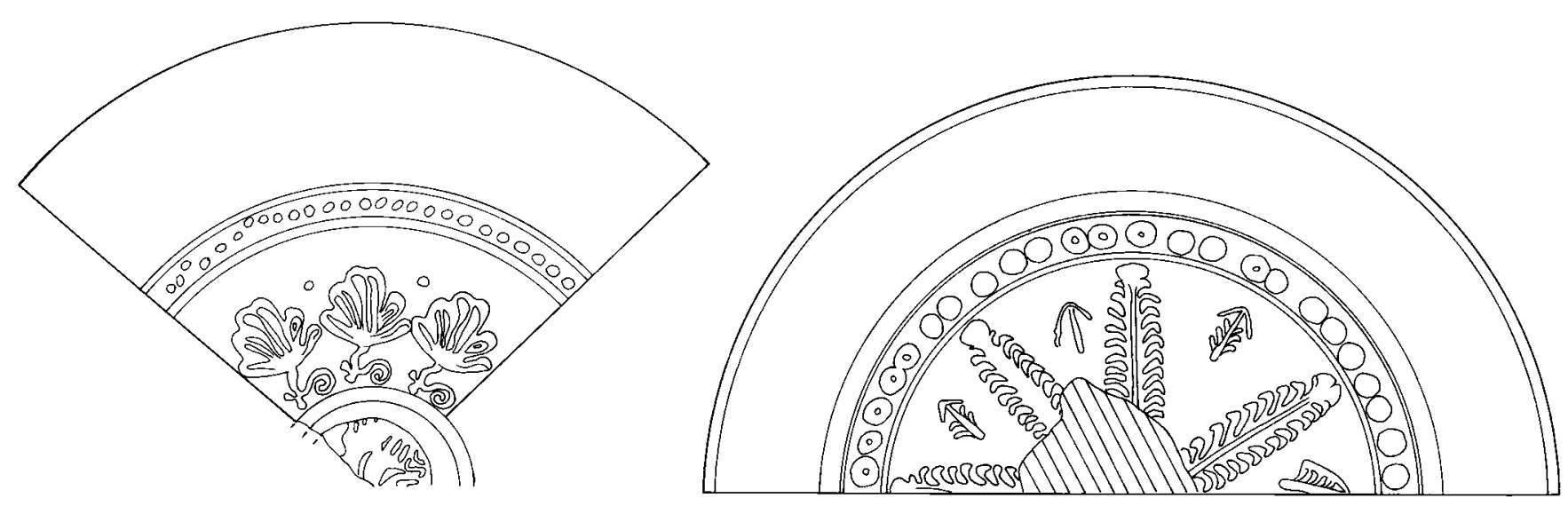

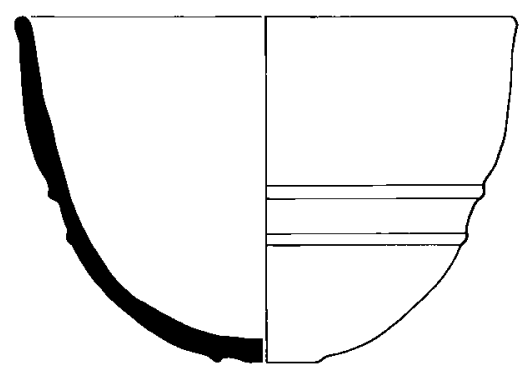

Cat.65

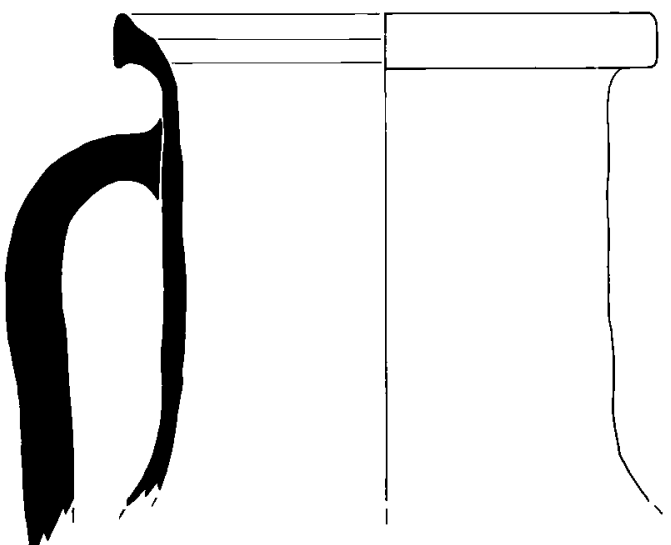

Cat.67
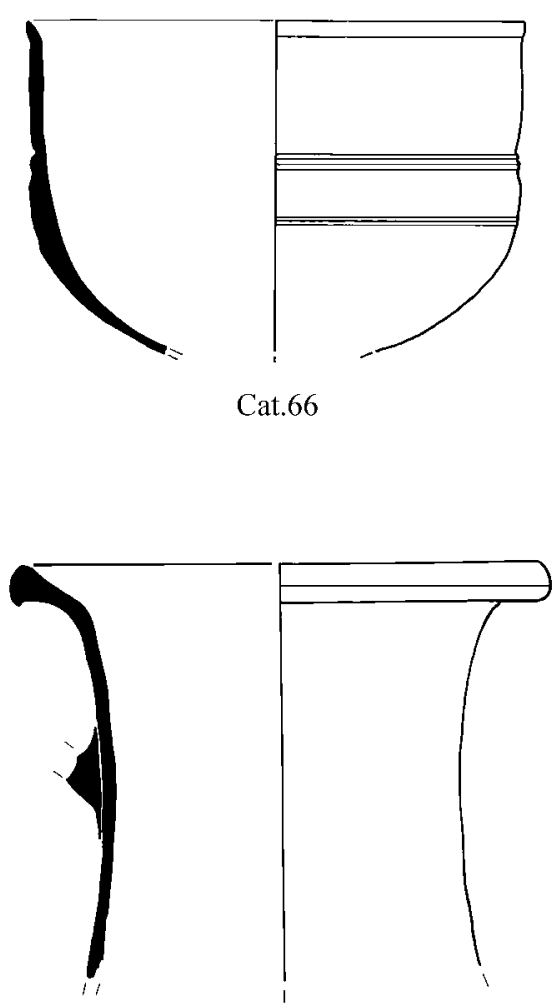

Cat.68

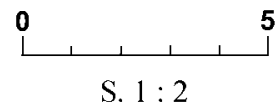




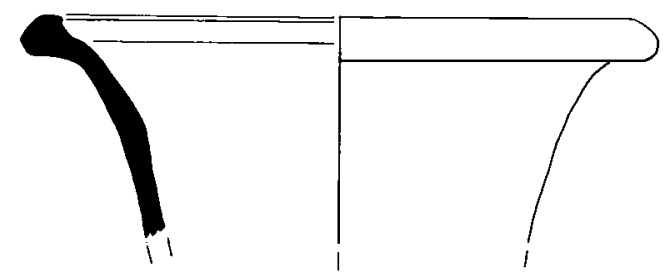

Cat.69

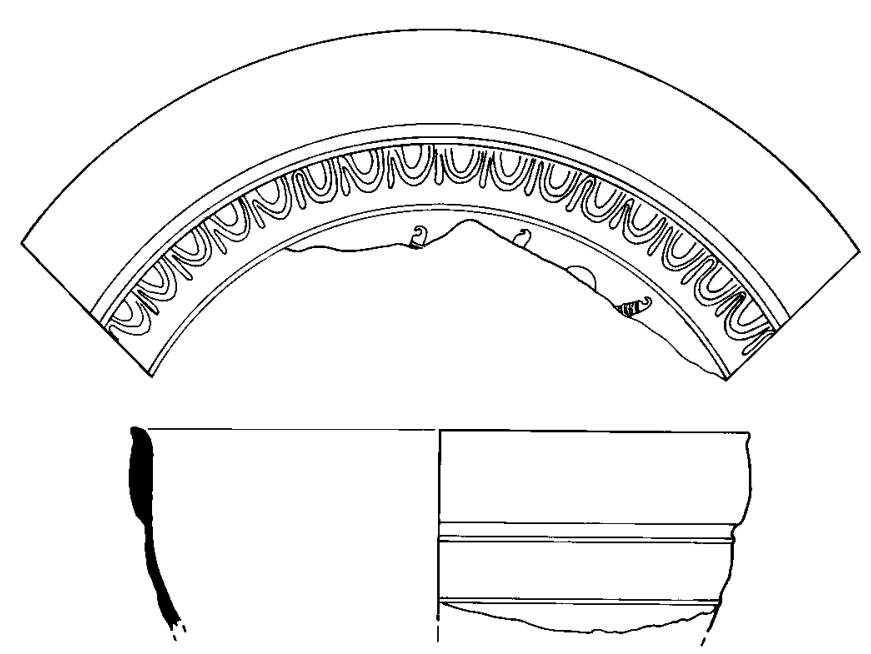

Cat.71

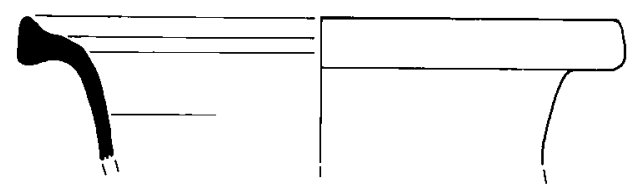

Cat.79

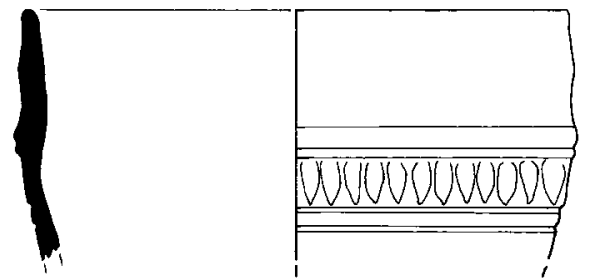

Cat. 81

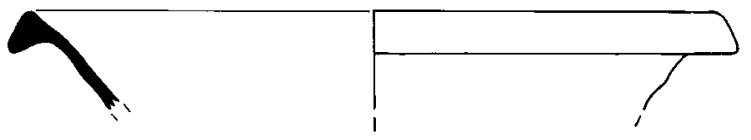

Cat.82c

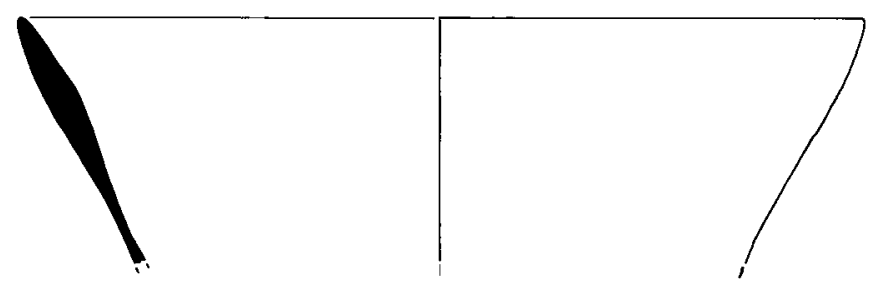

Cat. 70

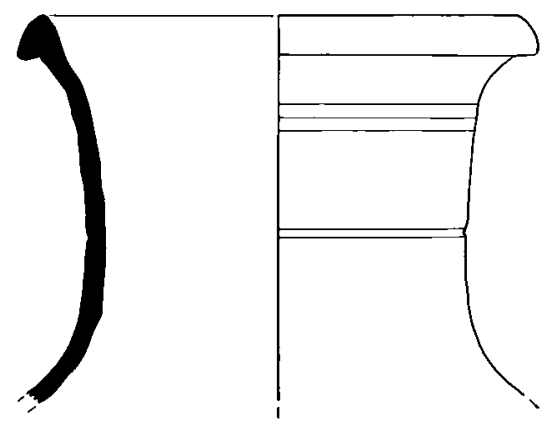

Cat. 78

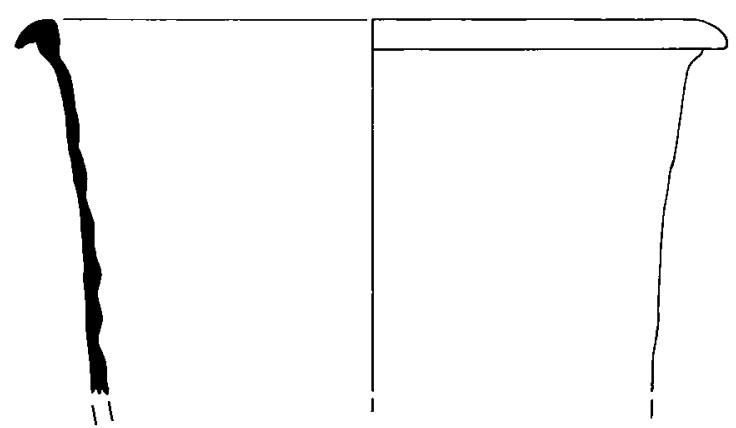

Cat.80

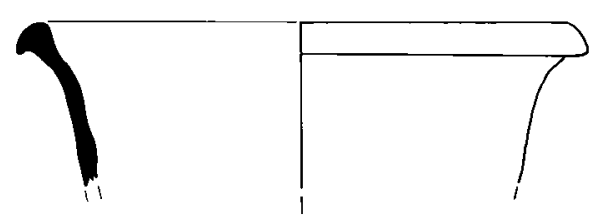

Cat. 82 a

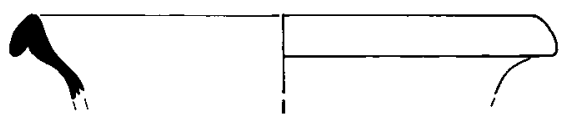

Cat. $82 \mathrm{~d}$

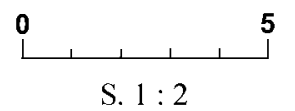




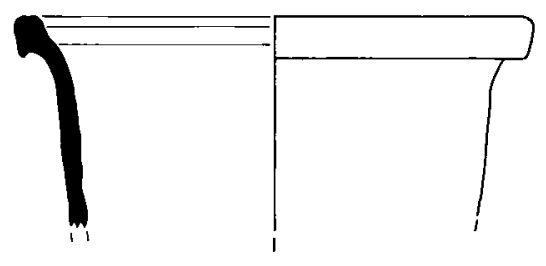

Cat.83a

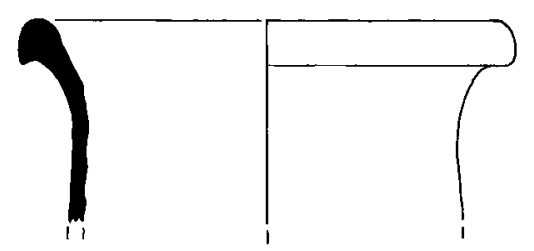

Cat. 83 b

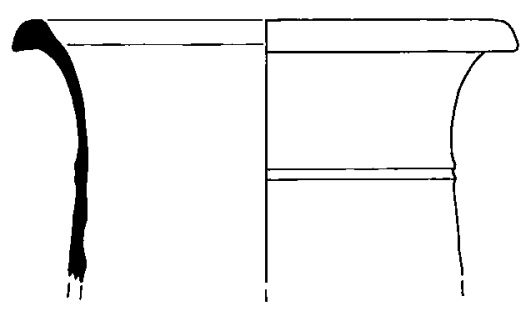

Cat.84 a

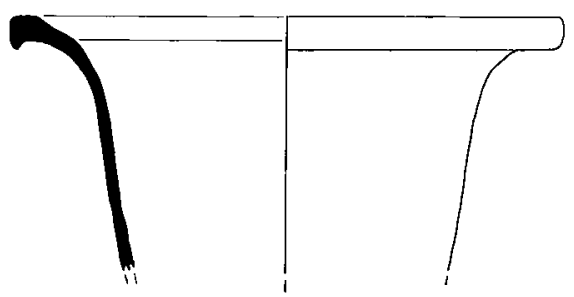

Cat.84b

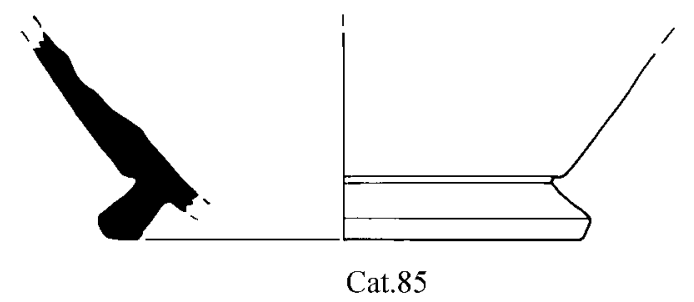

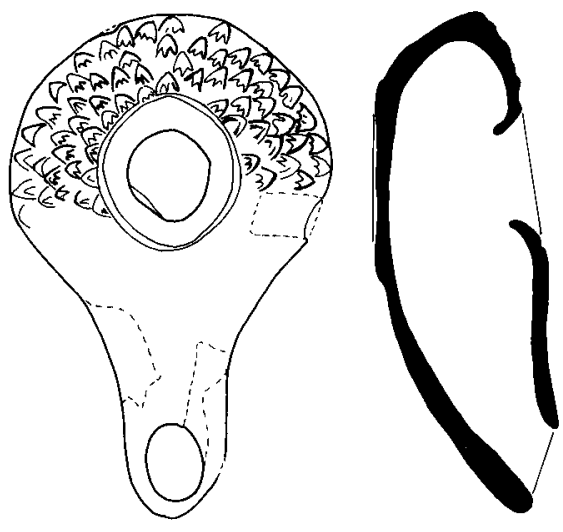

Cat.86

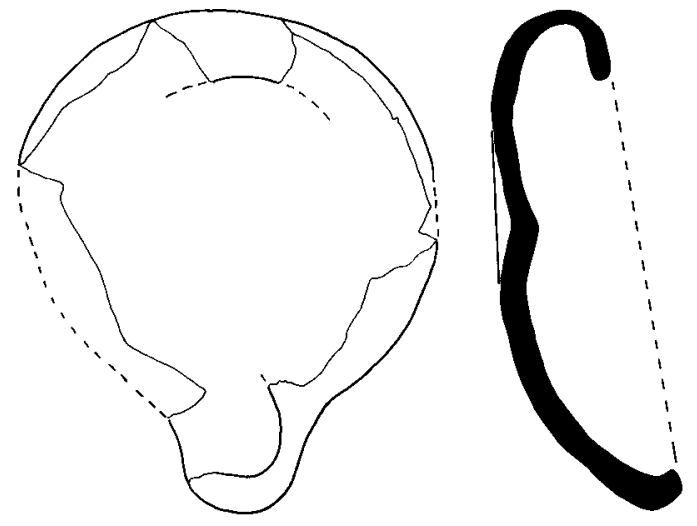

Cat. 87

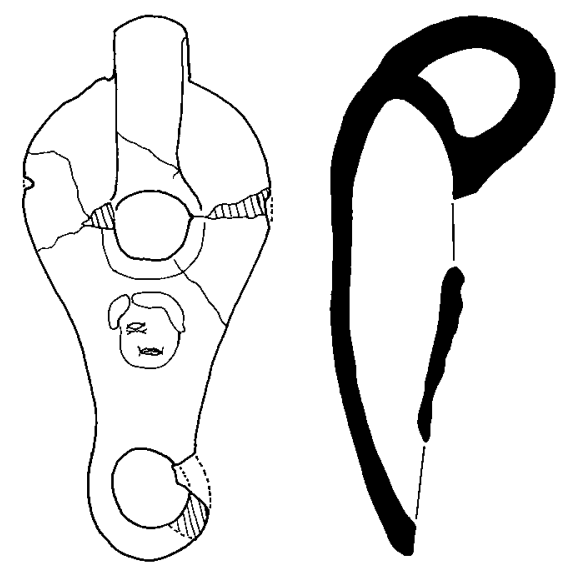

Cat.88

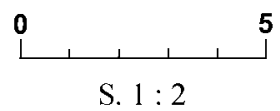




\section{Bibliography}

Abadie-Reynal 2003

Anderson 1954

Anderson Stojanovic 1992

Barker - Bonanno - Riley 1977

Barr 1996

Behr 1988

Berlin 1999

Blondé 1983

Bouzek - Jansova 1974

Bruneau 1965

Bruneau 1970

Buckler - Robinson 1932

Christensen - Johansen 1971

Chrzanovski - Zhuravlev 1998

Conze 1913

Courby 1922

Crowfoot - Crowfoot - Kenyon 1957 J. W. Crowfoot - G. M. Crowfoot - K. M. Kenyon, Samaria Sebaste. Reports of the Work of the Joint Expedition in 1931-1933 and of the British Expedition in 1935, Samaria 3 (London 1957).

Dinç 1993

Edwards 1975

Gassner 1997

Green 1990

Greenewalt 1978

Greenewalt 1979

Günay 1989

Günay Tuluk 1996

Gürler 1994

Gürler 2003

Gürler 2003b

Hanfmann 1959

Hanfmann 1983

Hanfmann - Waldbaum 1975

Hayes 1980

Hayes - Neuru 1991

Hellström 1965

Howland 1958

Jones 1950

Kassab Tezgör - Sezer 1995

Knigge 1976

Kögler 2000

C. Abadie-Reynal, Les céramiques en Anatolie aux époques hellénistique et romaine (Paris 2003)

J. K. Anderson, Excavation on the Kofinà Ridge, Chios, BSA 49, 1954, 123-182.

V. R. Anderson Stojanovic, Stobi. The Hellenistic and Roman Pottery (Princeton, N. J. 1992). (Malta 1977).

R. L. Barr, Greek and Hellenistic Lamps from Ilion, StTroica 6, 1996, 159-200.

D. Behr, Neue Ergebnisse zur pergamenischen Westabhangkeramik, IstMitt 38, 1988, 97-178.

A. M. Berlin, Studies in Hellenistic Ilion: The Lower City. Stratified Assemblages and Chronology, StTroica 9, 1999, 73-157.

F. Blondé, Greek Lamps from Thorikos, Miscellanea Graeca 6 (Gent 1983).

J. Bouzek - L. Jansova, Megarian Bowls, in: J. Bouzek (ed.), Kyme I. Anatolian Collection of Charles University (Prague 1974) 13-76.

Ph. Bruneau, Les Lampes, Délos 26 (Athens 1965).

$\mathrm{Ph}$. Bruneau, Tombes d'Argos, BCH 94, 1970, 437-531.

W. H. Buckler - D. M. Robinson, Greek and Latin Inscriptions I, Sardis 7 (Leyden 1932). hellénistiques et les terres sigillées orientales (Copenhagen 1971). Moscow (Rome 1998)

A. Conze (ed.), Altertümer von Pergamon I 2. Stadt und Landschaft: Die Stadt, AvP 1, 2 (Berlin 1913).

F. Courb.

R. Dinç, Lydia Tümülüsleri (unpublished dissertation Ege Üniversitesi İzmir 1993).

G. R. Edwards, Corinthian Hellenistic Pottery, Corinth 7, 3 (Princeton 1975).

V. Gassner, Das Südtor der Tetragonos-Agora. Keramik und Kleinfunde, FiE 13, 1, 1 (Vienna 1997).

P. Green, Alexander to Actium. The Historical Evolution of the Hellenistic Age (Berkeley 1990).

C. H. Greenewalt, Jr., Ritual Dinners in Early Historic Sardis (Berkeley 1978).

C. H. Greenewalt, The Sardis Campaign of 1977, BASOR 233, 1979, 3-32.

G. Günay, İzmir Müzesinde Bulunan Unguentariumlar (unpublished license thesis Ege Üniversitesi İzmir 1989).

G. Günay Tuluk, Ionia Bölgesi'nde Hellenistik Dönem Kandiller (unpublished dissertation Ege Üniversitesi İzmir 1996).

B. Gürler, Metropolis Hellenistik Dönem Seramiği (unpublished dissertation Ege Üniversitesi İzmir 1994).

B. Gürler, Hellenistic Ceramic of Metropolis in Ionia: Chronology, Production and Related Cities, in: Abadie-Reynal 2003, 9-16.

B. Gürler, Ephesos Lampen im Museum von Tire, ÖJh 72, 2003, 123-131.

G. M. A. Hanfmann, Excavations at Sardis, 1958, BASOR 154, 1959, 5-35.

G. M. A Hanfmann, Sardis from Prehistoric to Roman Times (Cambridge, MA 1983). City Walls, Archaeological Exploration of Sardis Report 1 (Cambridge, MA - London 1975).

J. W. Hayes, Ancient Lamps in the Royal Ontario Museum I. Greek and Roman Clay Lamps (Toronto 1980).

J. W. Hayes - L. L. Neuru, Paphos 3. The Hellenistic and Roman Pottery (Nicosia 1991).

P. Hellström, Labraunda: Swedish Excavations and Researches 2, 1. Pottery of Classical and Later Date. Terracotta Lamps and Glass (Lund 1965).

R. H. Howland, Greek Lamps and Their Survivals, Agora 4 (Princeton, NJ 1958).

F. F. Jones, The pottery, in: H. Goldman (ed.), Excavations at Gözlü Kule, Tarsus 1. The Hellenistic and Roman periods (Princeton, NJ 1950) 149-296.

D. Kassab Tezgör - T. Sezer, Catalogue des lampes en terre cuite du Musée Archéologique d'Istanbul, I. Epoques protohistorique, archaïque, classique et hellénistique, Varia Anatolica 6, 1 (Paris 1995).

U. Knigge, Der Südhügel, Kerameikos 9 (Berlin 1976).

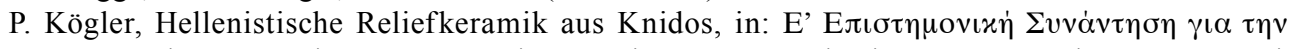

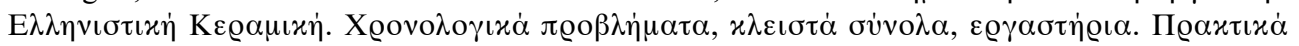
(Athens 2000) 189-194. 
Kotitsa 1996

Kotitsa 1998

Kurtz - Boardman 1971

Ladstätter 2005

Lang-Auinger 2003

Lapp 1961

Laumonier 1977

Liko 2001

McLauchlin 1985

Meriç 2002

Metzger 1994

Mitsopoulos-Leon 1991

Oziol 1997

Rogl 2001

Rogl 2005

Rotroff 1997

Rotroff - Oliver 2003

Schäfer 1968

Scheibler 1976

Sear 1979

Siebert 1978

Synantese 1994

Vessberg - Westholm 1956

von Prokesch 1831

Waagé 1941

Waldbaum 1983

Warner Slane 1997

Wiegand - Schrader 1904

Winkes 1985
Menzel 1954

Meyer-Schlichtmann 1988

Robinson 1959

Z. Kotitsa, Hellenistische Tonpyxiden. Untersuchung zweier hellenistischer Typen einer Keramikform (Mainz 1996).

Z. Kotitsa, Hellenistische Keramik im Martin von Wagner Museum der Universität Würzburg (Würzburg 1998).

D. Kurtz - J. Boardman, Greek Burial Customs (Ithaka, NY 1971).

S. Ladstätter, Keramik, in: H. Thür (ed.), Hanghaus 2 in Ephesos. Die Wohneinheit 4, Baubefund, Ausstattung, Funde, FiE 8, 6 (Vienna 2005) 230-358.

C. Lang-Auinger (ed.), Hanghaus 1 in Ephesos. Funde und Ausstattung, FiE 8, 4 (Vienna 2003).

P. W. Lapp, Palestinian Ceramic Chronology, 200-150 BC (New Haven 1961).

A. Laumonier, La céramique hellénistique à relief, 1. Ateliers >ioniens`, Délos 31 (Paris 1977).

H. Liko, Hellenistische Keramik aus der Grabung beim sogenannten Lukasgrab, in: F. Krinzinger (ed.), Studien zur hellenistischen Keramik in Ephesos, ErghÖJh 2 (Vienna 2001) 83-97.

B. McLauchlin, Lydian Graves and Burial Customs (unpublished dissertation Berkeley 1985).

H. Menzel, Antike Lampen im römisch-germanischen Zentralmuseum zu Mainz (Mainz 1954).

R. Meriç, Späthellenistisch-römische Keramik und Kleinfunde aus einem Schachtbrunnen am Staatsmarkt in Ephesos, FiE 9, 3 (Vienna 2002).

I. R. Metzger, Ein hellenistisches Grabmonument in Eretria, in: Synantese 1994, 71-79.

C. Meyer-Schlichtmann, Die pergamenische Sigillata aus der Stadtgrabung von Pergamon: Mitte 2. Jh. v. Chr. - Mitte 2. Jh. n. Chr., PF 6 (Berlin - New York 1988).

V. Mitsopoulos-Leon, Die Basilika am Staatsmarkt in Ephesos. Kleinfunde. 1. Teil: Keramik hellenistischer und römischer Zeit, FiE 9, 2, 2 (Vienna 1991).

T. Oziol, Salamine de Chypre 7. Les Lampes du Musée de Chypre (Paris 1977).

H. Robinson, Pottery of the Roman period, Agora 5 (Princeton, NJ 1959).

Ch. Rogl, Töpfersignaturen auf hellenistischen Reliefbechern. Eine Liste, ÖJh 70, 2001, 135-152.

Ch. Rogl, Ein Reliefbecher mit Kerdon-Signatur im Rijksmuseum van Oudheden, Leiden, ÖJh 74, 2005, 313-316.

S. I. Rotroff, Hellenistic Pottery: Athenian and Imported Wheelmade Tableware and Related Material, Agora 29 (Princeton, NJ 1997).

S. I. Rotroff - A. Oliver, Jr., The Hellenistic Pottery from Sardis. The Finds Through 1994 (Hollis 2003).

J. Schäfer, Hellenistische Keramik aus Pergamon, PF 2 (Berlin 1968).

I. Scheibler, Die griechischen Lampen, Kerameikos 11 (Berlin 1976).

D. Sear, Greek Coins \& Their Values II, Asia and North Africa (London 1979).

G. Siebert, Recherches sur les ateliers de bols à reliefs du Peloponnèse à l'époque hellénistique (Paris 1978).

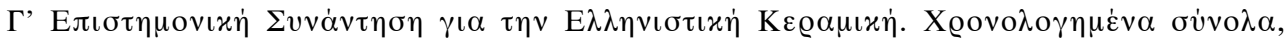

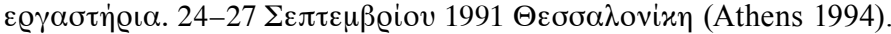

\section{6).}

A. von Prokesch, Erinnerungen aus Aegypten und Kleinasien (Vienna 1829-1831).

F. O. Waagé, Lamps. Antioch-on-the-Orontes 3. The Excavations 1937-1939 (Princeton, NJ 1941).

J. C. Waldbaum, Metalwork from Sardis: The Finds Through 1974 (London 1983).

K. Warner Slane, The fine wares, in: S. C. Herbert (ed.), Tel Anafa 2, 1. The Hellenistic and Roman pottery, JRA Suppl. 10 (Ann Arbor 1997) 247-393.

Th. Wiegand - H. Schrader, Priene, Ergebnisse der Ausgrabungen und Untersuchungen 1895-1898 (Berlin 1904).

R. Winkes, Love for Antiquity: Selections from the Joukowsky Collection (Providence - Louvainla-Neuve 1985).

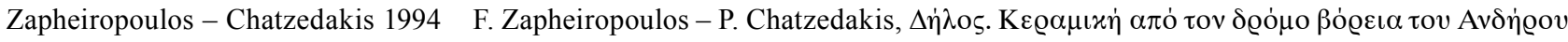

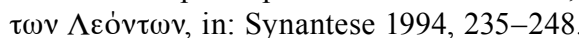

Ziegenaus - de Luca 1968 O. Ziegenaus - G. de Luca, Das Asklepieion, 1. Der südliche Temenosbezirk in hellenistischer und frührömischer Zeit, AvP 9, 1 (Berlin 1968).

\author{
Mag. Baran Aydin \\ Çeşme Museum, Çeşme Kalesi - TR- 35930 Izmir \\ E-Mail: baranaydin03@yahoo.com
}

Captions of figures: All figures and plates by the author. 
